\title{
LUCIA BALDASSI
}

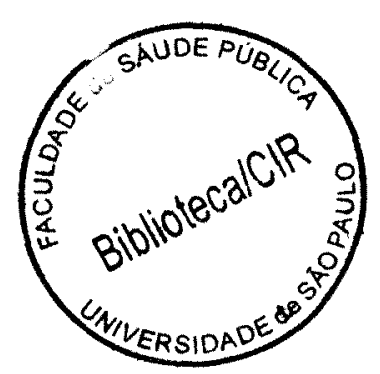

VERIFICAÇÃO DA TOXIGENICIDADE DE CEPAS DE Clostridium perfringens ISOLADAS DE MATERIAL DE ORIGEM BOVINA E SUA TIPIFICAÇÃO PELO ENSAIO IMUNOENZIMÁTICO E ELETROFORESE CORADA PARA ESTERASE

Tese apresentada à Faculdade de Saúde Pública da Universidade de São Paulo, para obtenção do título de Doutor Área: Serviços de Saúde Pública Orientador: Prof. Dr. Sebastião Timo laria 
Ao meu pai e irmã Edna pela Graça infinita da convivência. in memorian.

A minha mãe $M$. Apparecida e irmã Maria de Lourdes pela compreensão e sobretudo amor. 


\section{AGRADECIMENTOS}

Minha profunda gratidão àqueles que, de todas as formas estiveram presentes e assim, tornaram possivel a realização desse trabalho e em especial à:

meu orientador e amigo Dr. Sebastião Timo laria pela confiança, ensinamento, carinho e amizade;

Dr. Manuel A.S.C. Portugal pelo estímulo transmitido durante toda a minha carreira;

Dra. Margareth L.C. Guimarães do Instituto de Química da Universidade de São Paulo pela inestimável ajuda nos ensaios piloto de eletroforese;

Dra. Erna E. Bach da Seção de Bioquímica Fitopatológica do Instituto Biológico, com quem aprendi e realizei os ensaios de determinação do perfis enzimáticos, pela análise e interpretação dos resultados, pelo enriquecimento do aprendizado em computação e sobretudo despreendimento e amizade;

Dra. Maria Luisa Barbosa do Laboratório de Biologia Molecular do Instituto Adolfo Lutz, com quem realizei parte dos ensaios, pela participação ativa em todas as fases e pela amizade;

Dra. Elza M. Frias Martins pelo consentimento na utilização do Laboratório de Bioquímica Fitopatológica do Instituto Biológico na realização de alguns ensaios;

Dra. Rosa M. Piatti pelo auxilio nos ensaios imunológicos e pela amizade;

colegas e amigos da Seção de Bacteriologia Animal do Instituto Biológico, Dras. Ercilia M.B. Calil, Aurélia A.P. Moulin e Alberto Fernandes, pela colaboração e apoio demonstrados;

Sr. Walter Graeber, bibliotecário do Instituto Biológico, pelo grande apoio;

Dras. Julia Maria Martins Souza-Felippe e Luiza Terezinha Madia de Souza por permitirem a utilização do Laboratório de Biologia Molecular do Instituto Adolfo Lutz, onde foi realizada parte dos experimentos;

colegas do Laboratório Biovet Drs. Roberto Correa, Ronaldo Alves de Toledo Lima pela colaboração, cedendo cepas, meios de cultura, animais e, sobretudo, troca de experiência;

Silvana D'Agostini do Setor de Desenho do Instituto Biológico pela elaboração dos desenhos;

minha Instituição, Instituto Biológico, que possibilitou esta jornada;

a DEUS o agradecimento pelo exemplo que recebi dos outros. 
"C'est, je crois, le premier exemple connu.... d'animaux vivant sans gaz oxygêne libre".

Louis Pasteur, 1861. 
SUMÁRIO

Resumo

páginas

Summary

1. Introduçăo

2. Objetivos

01

3. Material de Métodos

3.1. Isolamento e identificação de $C$. perfringens a partir de

\section{amostras de necrópsia de bovinos}

3.1.1. Amostras analisadas

3.1.2. Isolamento e identificação bioquímica de $C$. perfringens nas amostras oriundas do campo

3.1.3. Cepas de teste e padrão utilizadas

3.2. Cultivo das cepas isoladas e padrão 24

3.2.1. Determinação da toxigenicidade das cepas isoladas e padrão 25

3.2.2. Extração de exopolissacarídeos (EPS) 26

3.2.2.1. Estimativa da concentração de carboidratos 26

3.2.2.2. Estimativa da concentração de proteínas 27

3.2.2.3. Determinação da toxigenicidade 27

3.2.3. Eletroforese dos sedimentos em gel de poliacrilamida 27

3.2.3.1. Estimativa da concentração de proteinas 27

3.2.3.2. Montagem das placas 28

3.2.3.3. Aplicação dos sedimentos das cepas 28

3.2.3.4. Voltagem e tempo de corrida 29

3.2.3.5. Coloração das esterases 29

3.2.3.6. Análise densitométrica 29

3.2.4. Teste sorológico dos sedimentos 29

3.2.4.1. Obtenção dos soros contra as cepas padrão (ATCC) tipos A, $B, C$ e $D$ de $C$. perfringens

3.2.4.2. Ensaio imunoenzimático (DAS-ELISA) 31

3.2.5. Exaltação da virulência das cepas 32

4. Resultados 33

4.1. Caracterização bioquimica das cepas 33

4.2. Determinação da toxigenicidade 33

4.3. Extração de exopolissacarídeos (EPS) 35

4.4. Caracterização e análise dos perfis eletroforéticos nos extratos $\begin{array}{ll}\text { bacterianos } & 37\end{array}$

4.5. Teste sorológico 53

4.6. Exaltação da virulência 55

4.7. Síntese dos resultados dos ensaios realizados 71

5. Discussão 78

6. Conclusões 89

7. Referências bibliográficas 90

8. Anexo 110 


\section{LISTA DE QUADROS, TABELAS E FIGURAS}

Quadros

página

Quadro 1. Classificação de C. perfringens segundo a produção de antigenos major (SMITH \& HOBBS, 1974).

Quadro 2. Toxinas produzidas pelos cinco tipos de C. perfringens (MCDONEL, 1980).

Quadro 3. Neutralização das toxinas produzidas pelos tipos de C. perfringens, por anti-soros específicos (McDONEL, 1980).

Quadro 4. Relação das cepas isoladas de $C$. perfringens de origem bovina, segundo a amostra de isolamento e região de procedência. São Paulo, 1997.

Quadro 5. Toxigenicidade das 89 cepas de teste de $C$. perfringens, isoladas de amostras de origem bovina, detectada em sobrenadantes de cultura não tripsinizados e tripsinizados. São Paulo, 1997.

Quadro 6. Classificação das 89 cepas de C. perfringens isoladas, baseada nos testes de toxigenicidade, ELISA e eletroforese. São Paulo, 1997.

Quadro 7. Resultados obtidos nos testes de tipagem por ELISA e eletroforese corada para esterase e nos de toxigenicidade de 20 cepas de $C$. perfringens de teste isoladas, relacionando-os ao órgão de isolamento e origem (Estado e cidade), agrupados para um único bovino. Săo Paulo, 1997

Quadro 8. Resultados obtidos nos testes de tipagem por ELISA e eletroforese corada para esterase e nos de toxigenicidade de 20 cepas de $C$. perfringens de teste isoladas, relacionando-os ao órgão de isolamento e origem (estado e cidade), agrupados para bovinos diferentes. São Paulo, 1997. 
Tabelas

Tabela 1. Quantificação de carboidratos (carb) em $\mathrm{mg} / \mathrm{mL}$, proteínas página (prot) em $\mathrm{mg} / \mathrm{mL}$, sua relaçāo (carb/prot) e toxigenicidade para camundongos observados nos extratos de EPS das 89 cepas de $C$. perfringens de teste isoladas. São Paulo, 1997.

Tabela 2. Valores da porcentagem de volume, área, média de absorbância e relação absorbância $x$ área apresentados pelas bandas da eletroforese corada para esterase, de cepas de $C$. perfringens, padrão ATCC 3624 tipo A, 3626 tipo B, 3628 tipo C e 3629 tipo D e das 89 de teste isoladas. São Paulo, 1997

Tabela 3. Valores das absorbâncias obtidos no teste de ELISA para cepas de $C$. perfringens padrão ATCC 3624 tipo A, 3626 tipo B, 3628 tipo C e 3629 tipo D, frente a anti-soros contra estas mesmas cepas obtidos em coelhos. São Paulo, 1997.

Tabela 4. Valores das absorbâncias obtidos no teste de ELISA para as 89 cepas de $C$. perfringens de teste isoladas, frente a anti-soros contra cepas padrão ATCC 3624 tipo A, 3626 tipo B, 3628 tipo C e 3629 tipo D. São Paulo, 1997.

Tabela 5. Valores da porcentagem de volume, área, média de absorbância e relação absorbância $x$ área apresentados pelas bandas de eletroforese corada para esterase, de cepas de $C$. perfringens padrão ATCC 3624 tipo A, 3626 tipo B, 3628 tipo C, 3629 tipo D e 10 de teste isoladas, nas formas original (o) e com virulência exaltada (e). São Paulo, 1997.

Tabela 6. Distribuição do número de cepas de $C$. perfringens de teste isoladas, de amostras de origem bovina, segundo os tipos, de acordo com os testes de ELISA e eletroforese corada para esterase. Săo Paulo, 1997. 
Figura 1. Densitometria do gel de poliacrilamida, corado para esterase, de corrida eletroforética de cepas de $C$. perfringens padrão ATCC 3624 tipo A, 3626 tipo B, 3628 tipo C e 3629 tipo D. São Paulo, 1997.

Figura 2. Densitometria do gel de poliacrilamida, corado para esterase, de corrida eletroforética de duas cepas de $C$. perfringens de teste isoladas, identificadas para cada um dos tipos, e duas não identificadas. São Paulo, 1997.

Figura 3. Gráfico da migração eletroforética de gel corado para esterase, de cepas de C. perfringens padrão ATCC 3624 tipo A e de teste isoladas números 1, 9, 48, 75. São Paulo, 1997.

Figura 4. Gráfico da migração eletroforética, de gel corado para esterase, de cepas de $C$. perfringens padrão ATCC 3626 tipo B e de teste isoladas números 12, 83 e 88. São Paulo, 1997.

Figura 5. Gráfico da migração eletroforética, de gel corado para esterase, de cepas de C. perfringens padrão ATCC 3628 tipo C e de teste isoladas números 13, 14, 36 e 40. São Paulo, 1997.

Figura 6. Gráfico da migração eletroforética, de gel corado para esterase, de cepas de C. perfringens padrão ATCC 3629 tipo $D$ e de teste isoladas números $47,50,53$ e 58. São Paulo, 1997

Figura 7. Dendograma da migração eletroforética das bandas de esterase, de acordo com a leitura densitométrica do gel de corrida das cepas padrão ATCC 3624, 3626, 3628 e 3629 , de $C$. perfringens, respectivamente, tipos $A, B, C$ e $D$ e de 22 de teste isoladas, São Paulo. 1997.

Figura 8. Dendograma da migração eletroforética das bandas de esterase, de acordo com a leitura densitométrica do gel de corrida das cepas de $C$. perfringens, padrão ATCC 3624 , 3626, 3628 e 3629, respectivamente, tipos A, B, C e D e de 22 de teste isoladas. Sảo Paulo, 1997. 
Figura 9. Dendograma da migração eletroforética das bandas de esterase, de acordo com a leitura densitométrica do gel de corrida das cepas de $C$. perfringens padrão ATCC 3624, 3626,3628 e 3629 , respectivamente, tipos A, B, C e D e de 22 de teste isoladas. São Paulo, 1997.

Figura 10. Dendograma da migração eletroforética das bandas de esterase, de acordo com a leitura densitométrica do gel de corrida das cepas de $C$. perfringens padrão ATCC 3624 , 3626,3628 e 3629 , respectivamente, tipos A, B, C e D e de 23 de teste isoladas. São Paulo, 1997.

Figura 11. Densitometria e gráfico da migração eletroforética do gel de poliacrilamida corado para esterase, da cepa de C. perfringens padrão ATCC 3624 do tipo $A$, na sua forma original $\left(A_{0}\right)$ e com virulência exaltada $\left(A_{e}\right)$. São Paulo, 1997.

Figura 12. Densitometria e gráfico da migraçăo eletroforética do gel de poliacrilamida, corado para esterase, da cepa de $C$. perfringens padrão ATCC 3626 do tipo $B$, na sua forma original $\left(B_{o}\right)$ e com virulência exaltada $\left(B_{e}\right)$. São Paulo, 1997.

Figura 13. Densitometria e gráfico da migração eletroforética do gel de poliacrilamida, corado para esterase, da cepa de $C$. perfringens padrão ATCC 3628 do tipo $\mathrm{C}$, na sua forma original $\left(C_{0}\right)$ e com virulência exaltada $\left(C_{e}\right)$. São Paulo, 1997.

Figura 14. Densitometria e gráfico da migração eletroforética do gel de poliacrilamida, corado para esterase, da cepa de $C$. perfringens padrão ATCC 3629 do tipo $D$, na sua forma original $\left(D_{0}\right)$ e com virulência exaltada $\left(D_{e}\right)$. Săo Paulo, 1997.

Figura 15. Densitometria e gráfico da migração eletroforética do gel de poliacrilamida, corado para esterase, da cepa $n^{\circ} 10 \mathrm{C}$. perfringens de teste isolada, na sua forma original $\left(10_{0}\right)$ e com virulência exaltada $\left(10_{e}\right)$. São Paulo, 1997. 
Figura 16. Densitometria e gráfico da migração eletroforética do gel de poliacrilamida, corado para esterase, da cepa $n^{\circ} 11$ de $C$. perfringens de teste isolada, na sua forma original (110) e com virulência exaltada (11e). São Paulo, 1997.

Figura 17. Densitometria e gráficao da migração eletroforética do gel de poliacrilamida, corado para esterase, da cepa $n^{\circ} 12$ de C. perfringens de teste isolada, na sua forma original (120) e com virulência exaltada (12,). São Paulo, 1997.

Figura 18. Densitometria e gráfico da migração eletroforética do gel de poliacrilamida, corado para esterase, da cepa $n^{\circ} 19$ de $C$. perfringens de teste isolada, na sua forma original (190) e com virulência exaltada (19. $)$. São Paulo, 1997.

Figura 19. Densitometria e gráfico da migração eletroforética do gel de poliacrilamida, corado para esterase, da cepa $n^{\circ} 20$ de $C$. perfringens de teste isolada, na sua forma original $\left(20_{0}\right)$ e com virulência exaltada $\left(20_{e}\right)$. São Paulo, 1997.

Figura 20. Densitometria e gráfico da migração eletroforética do gel de poliacrilamida, corado para esterase, da cepa $n^{\circ} 23$ de $C$. perfringens de teste isolada, na sua forma original $\left(23_{0}\right)$ e com virulência exaltada (23, ). São Paulo, 1997.

Figura 21. Densitometria e gráfico da migração eletroforética do gel de poliacrilamida, corado para esterase, da cepa $n^{\circ} 26$ de $C$. perfringens de teste isolada, na sua forma original (26.) e com virulência exaltada (26.). São Paulo, 1997.

Figura 22. Densitometria e gráfico da migração eletroforética do gel de poliacrilamida, corado para esterase, da cepa $n^{\circ} 27$ de $C$. perfringens de teste isolada, na sua forma original $\left(27_{0}\right)$ e com virulência exaltada (27.). São Paulo, 1997.

Figura 23. Densitometria e gráfico da migração eletroforética do gel de poliacrilamida, corado para esterase, da cepa $n^{\circ} 68$ de $C$. perfringens de teste isolada, na sua forma original $\left(68_{0}\right)$ e com virulência exaltada (68 $)$. São Paulo, 1997.

Figura 24. Densitometria e gráfico da migração eletroforética do gel de poliacrilamida, corado para esterase, da cepa $n^{\circ} 88$ de $C$. perfringens de teste isolada, na sua forma original $\left(88_{\circ}\right)$ e com virulência exaltada (88 $)$. São Paulo, 1997. 
RESUMO

Cento e oitenta e sete amostras de diferentes tecidos provenientes de 71 bovinos, oriundos de vários Estados do pais, foram processados para isolamento de microrganismos anaeróbios, sendo de cada uma delas isolada pelo menos uma cepa, caracterizada como Clostridium spp. Destas, 144 foram identificadas bioquimicamente como C. perfringens selecionando-se, aleatoriamente, 89 delas com 0 intuito de classificá-las segundo os tipos. As 89 cepas foram assim constituidas: fígado 32 , conteúdo intestinal $19, \mathrm{rm} 14$, rúmen 6 , sistema nervoso central 5 , medula de osso metatarsiano 4, mama 2, sangue 2, baço 2, pulmão 2 e músculo 1. Estas cepas e as padrão ATCC tipos A, B, C e D foram cultivadas em meios apropriados, seus cultivos submetidos à centrifugação e os sobrenadantes e sedimentos separados. A partir dos sobrenadantes foi efetuado o teste de toxigenicidade para camundongos e a extração de exopolissacarideos. Nestes exopolissacarideos foram determinadas as concentrações de proteinas e carboidratos e também realizados testes de toxigenicidade para camundongos. Com os sedimentos foi realizada a eletroforese corada para esterase e o ensaio imunoenzimático (ELISA), ambos para tipificação das cepas em relação às padrão. As quatro cepas padrão e 10 das isoladas, em suas formas original e após a exaltação da virulência em cobaias, foram também submetidas a eletroforese corada para esterase. Os resultados mostraram que a maioria das cepas, $51(57,3 \%)$, era toxigênica, portanto potencialmente patogênicas; que diferentes órgãos apresentaram cepas com toxigenicidade variável e a predominância do tipo $\mathrm{A}$ tanto pelo teste de ELISA $(40,4 \%)$ quanto pela eletroforese $(48,3 \%)$, seguido pelo $D(33,7 \%$ e $22,5 \%$, respectivamente). A toxigenicidade dos extratos de exopolissacarídeos só foi observada quando os niveis de proteina estavam em $0,04 \mathrm{mg} / \mathrm{mL}$ e os de carboidrato entre 0,31 a $0,59 \mathrm{mg} / \mathrm{mL}$, tendo sido observada identidade nas cepas toxigênicas determinadas nos sobrenadantes de cultivo e nestes extratos. A eletroforese em relação à sorologia mostrou-se um bom método de classificação, uma vez que estes apresentaram, respectivamente, $94,4 \%$ e $86,4 \%$ de definição nos resultados. Ressaltase a ocorrencia de $39,3 \%$ de identidade nos resultados obtidos nestas duas provas o que permite sugerir o emprego de mais um teste na classificação de $C$. perfringens. Das cepas cuja virulência foi exaltada, 2 mostraram, em eletroforese corada para esterase, variação no número de bandas, apresentando porém a mesma mobilidade relativa. 
SUMMARY

One hundred eighty seven clinical samples of 71 bovine, originated from many states of Brazil, were processed for anaerobes with the isolation of, at least one strains of Clostridium spp. From those, 144 were biochemically identified as $C$. perfringens selecting, at random, 89 in order to stablish the types prevalence. Those 89 selected strains consisted of: liver 32 , intestinal contents 19 , kidney 14 , rumen 6 , nervous sister 5 , bone marrow 4 , mama 2 , blood 2 , spleen 2, lung 2 e muscle 1 , selected from the same or different animals. The selected strains and the ATCC strains types A, B, C and D, were cultivated in appropriated media, their cultures were centrifuged and the supernatant and sediment were separated. From the supernatants were performed toxigenicity tests to mice and exopolissacharides (EPS) extraction. From the EPS were determinated protein and carbohydrate concentrations and also made mice toxigenicity tests. From the sediments were done esterase electrophoresis and enzyme linked immunosorbent assay, both for the strains tipification. Those tests were compared with those obtained for ATCC strains. It was also done esterase electrophoresis of the ATCC and 10 isolated strains before and after virulence exaltation in guinea pigs. The results showed that the majority of the strains, 51 $(57,30 \%)$, were toxigenic, though potentially pathogenic; strains isolated from different organs had variable toxigenic pattern and there was a type $A$ predominance by ELISA $(40,4 \%)$ and by electrophoresis $(48,3 \%)$, followed by $D$ $(33,7 \%$ and $22,5 \%$, respectively. The EPS extracts toxigenicity was only present when protein level was $0,04 \mathrm{mg} / \mathrm{mL}$ and the carbohydrate was between 0,31 and $0,50 \mathrm{mg} / \mathrm{mL}$. The strains identified as toxigenic by this test were too in the culture supernatants. Electrophoresis showed to be a good classification method, compared to the sorology, as those presented, respectively, 94,4 and $86,40 \%$ of results definition. Both methods presented $39,3 \%$ of identity, suggesting, in that way the necessity of more than one test for the $C$. perfringens classification. Two among all strains with virulence exaltated, showed, in esterase electrophoresis differences related to band number, but not in terms of relative electrophoretic mobility. 


\section{INTRODUÇÃO}

A importância das bactérias anaeróbias pode ser bem aquilatada no comentário de MEDEIROS (1972) sobre infecçōes causadas por estes agentes: "a medicina e a microbiologia devem trabalhar juntas, caso contrário, uma vez mais, todo o mundo se tornará anaeróbio".

A identificação de microrganismos anaeróbios específicos do gênero Clostridium permitiu a caracterização de doenças, com manifestações clínicas diversas, tais como: tétano, botulismo, gangrenas gasosas e enterotoxemias.

Graças aos avanços tecnológicos, nos anos 60 , estudos realizados nas áreas de bacteriologia e clínica, continuaram a enfatizar a participação dos microrganismos anaeróbios em enfermidades humanas e animais. Estes estudos afastaram certos conceitos errôneos em relação ao potencial de causar doença, dos microrganismos anaeróbios endógenos do organismo humano (BALOWS, 1975).

Tem sido verificado que a microbiota do homem é composta principalmente de microrganismos anaeróbios em relação a aeróbios ou seja, 10:1 na vagina, cavidade oral e pele e 1.000:1 no intestino grosso. Isto torna mais aceitável o fato de que doenças que ocorrem no homem, no transcorrer de sua vida, sejam as causadas muito mais por microrganismos anaeróbios de origem endógena do que exógena, embora, as infecções determinadas por anaeróbios sejam as que apresentam menor freqüência de diagnóstico, tanto clínico quanto microbiológico. Pouco se sabe sobre o papel da microbiota normal do organismo, sobretudo do trato intestinal, nos mecanismos da nutrição e da fisiologia. Mesmo assim, qualquer que seja este papel, as bactérias anaeróbias devem ter uma participaçăo importante, uma vez que são claramente predominantes na microbiota endógena (MEDEIROS, 1972). 
A virulência destas bactérias é dada pela produção de toxinas elaboradas durante o período de multiplicação bacteriana, causando infecções, como por exemplo o tétano (Clostridium tetani) e intoxicaçōes, que não determinam infecção, como é o caso da toxinfecção alimentar causada pelo Clostridium botulinum.

A história dos anaeróbios se inicia, na idade média, com o reconhecimento, pela área médica, da mionecrose ou gangrena gasosa e, provavelmente, seja ainda hoje, a mais conhecida de todas as infecções anaeróbias. Porém, foi a partir de 1870 que esta patologia começou a atrair a atenção de estudiosos. Primariamente, foi considerada uma enfermidade relacionada à guerra, pois são inúmeras as publicações desta época, descrevendo casos de gangrena gasosa, enfermidade rara, porém freqüente nos períodos de guerra (MACLENNAN, 1962).

Em 1871 BOTTINI (apud MACLENNAN, 1962) demonstrou a natureza bacteriana desta doença, sem contudo identificar o agente etiológico. Neste mesmo periodo é reconhecida, em bovinos, uma doença similar e, em 1879 seu agente causal, um bacilo anaeróbio, foi identificado e denominado Bacterium chauvoei.

Além da gangrena gasosa do homem e a manqueira ("black leg") dos animais, uma terceira forma da doença foi identificada em 1881 e denominada edema maligno. Após um periodo de trinta anos de pesquisas de ambas as ocorrências em Lyon (França), CHAUVEAU e ARLOING (1884) demonstraram que a gangrena gasosa e o edema maligno eram uma única doença causada pelo mesmo microrganismo anaeróbio (Vibrion septique, segundo Pasteur e Oedembazillus, de acordo com Koch).

A primeira descrição de Clostridium perfringens é atribuida a ACHALME (1891), o qual relatou, em um caso humano de reumatismo articular 
agudo, a presença de bastonetes Gram-positivos anaeróbios e produtores de esporos em culturas velhas, semelhante ao Bacillus anthracis. Em 1892, WELCH \& NUTTALL descreveram uma bactéria com caracteristicas semelhantes, isolada de materiais de necrópsia de um individuo que apresentava bolhas de gás nos vasos sangüíneos, a qual denominaram Bacillus aerogenes capsulatus. Posteriormente cerca de oito denominações se seguiram, de acordo com SIMONDS (1915) que classificou este microrganismo, em quatro subgrupos, com base nas suas características bioquímicas; esta posição taxonômica, mais tarde, foi aceita por alguns pesquisadores (HALL, 1922 e HOWARD, 1928), porém criticada por outro (HUMPHREYS, 1924). Deve ser salientado que esta classificação é mantida até o presente momento.

As bactérias pertencentes à espécie $C$. perfringens são classificadas na familia Bacillaceae, membros do gênero Clostridium, sendo relacionados antigenicamente com $C$. bifermentans e $C$. sordellii. Caracterizam-se como bacilos retos, Gram-positivos, em culturas jovens, medindo entre 0,9-1,3 $\mu \mathrm{m}$ de largura por 3,0-9,0 $\mu \mathrm{m}$ de comprimento, com extremidades arredondadas e cápsula bem definida. À exceção dos demais clostrídios patogênicos, são imóveis e raramente formam esporos tanto nos tecidos onde se multiplicam, quanto nos meios de cultivo usuais de laboratório. Em ágar sangue formam colônias circulares, planas, amarelo-acinzentadas, com, aproximadamente, 2 a $5 \mathrm{~mm}$ de diâmetro, superfície brilhante e, em geral, circundadas por dupla zona de hemólise (CATO e cols., 1986; HOLT e cols., 1994).

Segundo SMITH \& HOBBS (1974) são anaeróbios, não redutores do sulfato, hidrolisam a gelatina, fermentam carboidratos e, tempestuosamente, o leite. Produzem esporos ovais subterminais que raramente são observados em meios usuais de cultivo.

Dos microrganismos patogênicos, o $C$. perfringens parece ser o mais amplamente distribuido (ESTY, 1920; HATHEWAY, 1990; ROOD \& COLE, 1991) e, segundo WILLIS (1969), não existem situaçōes expostas às condições 
ambientais habituais, em que este microrganismo não esteja presente. $\dot{E}$ considerado agente prevalente do solo, esgotos e trato intestinal do homem e dos animais (ESTY, 1920; MACLENNAN, 1962; STERN \& VAN HEYNINGEN, 1965; WILLIS, 1969; SMITH, 1975).

Sua distribuição com relação aos tipos não é uniforme, havendo predominio do tipo $A$, acreditando-se que o solo seja seu ambiente natural (TAYLOR \& GORDON 1940; WILLIS, 1969; SMITH, 1975), sendo encontrado também em fezes de algumas espécies animais (TAYLOR \& GORDON 1940). Os demais tipos de $C$. perfringens estão, predominantemente, relacionados ao trato intestinal de animais e a presença destes no solo ocorre pela contaminação fecal (WILLIS, 1969; SMITH, 1975).

BULL e PRITCHETT, em 1917, preconizaram a classificação do C. perfringens por meio de testes de neutralização da toxina "in vivo" e observaram, também, que a necrose e hemólise produzidas por filtrados de culturas eram determinadas por uma exotoxina. Verificaram, ainda, que esta toxina tinha poder imunogênico e que sua antitoxina neutralizava, "in vivo" e "in vitro", toxinas dos outros tipos de $C$. perfringens. $O$ referido teste foi aceito pelo MEDICAL RESEARCH COUNCIL (MRC), (1919)

Testes de aglutinação também foram tentados visando a classificação do $C$. perfringens, porém, frente aos resultados insatisfatórios, o MRC não os referendou para sua identificação (MACLENNAN, 1962).

Na Inglaterra, DALLING isolou em 1938, de casos de disenteria de carneiros, uma bactéria que foi classificada como Bacillus agni cuja exotoxina neutralizava a toxina de $C$. perfringens, porém o inverso não ocorria. Segundo WILSDON (1931), os padrões, muito rígidos, empregados na época para a identificação fizeram com que o $C$. perfringens fosse classificado como Bacillus agni. 
Em 1930, McEWEN isolou da mesma espécie animal, também na Inglaterra, cepas com morfologia e características de cultivo idênticas às de $C$. perfringens, mas que apresentavam variação na especificidade de suas toxinas (MCEWEN, 1931). A antitoxina de $C$. perfringens não neutralizava as toxinas produzidas por estas cepas e anti-soros preparados contra elas não neutralizavam o efeito patogênico das culturas de $C$. perfringens, levando-o a crer que se tratava de outra espécie bacteriana, à qual denominou Bacillus paludis (MCEWEN, 1930).

Por outro lado, WILSDON (1931) verificou que as amostras de $C$. perfringens, $B$. agni e $B$. paludis não diferiam, morfológica e bioquimicamente, de modo significativo e observou também que, para a classificação, a estrutura antigênica obtida pela reação toxina-antitoxina era mais importante do que as caracteristicas bioquímicas. Assim, WILSDON (1931, 1932/1933) estabeleceu para o Clostridium perfringens a existência de quatro tipos sorológicos; A, B, C e $D$, incluindo nesta classificação o $B$. ovitoxicus, isolado por BENNETTS (1932).

GLENNY e cols., (1933) complementaram o estudo de WILSDON (1932/33) acrescentando outras características como hemólise, necrose e letalidade, sugerindo, também, o uso de letras gregas para a identificação das toxinas. Aos quatro tipos de WILSDON (1932/33) incluiram-se cepas isoladas por BOSWORTH em 1943, as quais, mais tarde, foram classificadas como tipo $E$ (ROSS e cols., 1949).

Posteriormente o estudo destas cepas determinou a classificação em tipos com base na produção dos antígenos major. alfa $(\alpha)$, beta $(\beta)$, epsilon $(\varepsilon)$ e iota (1) (STERN \& WARRACK, 1964). Atualmente são reconhecidos cinco tipos de $C$. perfringens (Quadro 1), caracterizados por estes antígenos, os quais apresentam atividade letal, nos testes "in vivo" (SMITH \& HOBBS, 1974). 
Quadro 1. Classificação de $C$. perfringens segundo a produção de antígenos major (SMITH \& HOBBS, 1974).

\begin{tabular}{ccccc}
\hline Tipos de & \multicolumn{5}{c}{ Antigenos major } \\
\cline { 2 - 5 } C. perfringens & $\alpha$ & $\beta$ & $\varepsilon$ & - \\
\hline $\mathrm{A}$ & ++ & - & + & - \\
\hline $\mathrm{B}$ & + & ++ & - & - \\
\hline $\mathrm{C}$ & + & ++ & ++ & - \\
\hline $\mathrm{D}$ & + & - & - & + \\
\hline E & + & - & & ++ \\
\hline++ & produtor, fração tóxica predominante & & \\
+ produtor, em menor quantidade & & & \\
- & não produtor
\end{tabular}

Outros estudos foram realizados e culminaram com a descoberta dos antígenos minor [delta $(\delta)$, teta $(\theta)$, capa $(\kappa)$, lambda $(\lambda)$, mi $(\mu)$, ni $(\nu)$, eta $(\eta)$ e gama $(\gamma)$ ], a neuraminidase (nm) e a enterotoxina (en) (Quadro 2). Entretanto, estes antígenos não são significativos na determinação dos tipos, mas sim na identificação de sub-tipos, fundamentais para levantamentos epidemiológicos (OAKLEY \& WARRACK, 1953; BROOKS e cols., 1957; STERN \& WARRACK, 1964; HAUSCHILD, 1971) (Quadro 2).

Quadro 2. Toxinas produzidas pelos cinco tipos de C. perfringens (MCDONEL, 1980).

\begin{tabular}{|c|c|c|c|c|c|c|c|c|c|c|c|c|c|c|}
\hline \multirow{3}{*}{$\begin{array}{c}\text { C. perfringens } \\
\text { tipo }\end{array}$} & \multicolumn{14}{|c|}{ Toxinas produzidas } \\
\hline & \multicolumn{4}{|c|}{ major } & \multicolumn{6}{|c|}{$\operatorname{minor}$} & & \multicolumn{3}{|c|}{ outras } \\
\hline & $\alpha$ & $\beta$ & $\varepsilon$ & 1 & $\delta$ & $\theta$ & $\kappa$ & $\lambda$ & $\mu$ & $v$ & $\eta$ & $\gamma$ & en & $\mathrm{nm}$ \\
\hline$A$ & + & - & - & - & - & + & + & - & + & + & \pm & - & + & + \\
\hline $\mathrm{B}$ & + & + & $(+)$ & - & + & + & + & + & + & + & - & \pm &. & + \\
\hline $\mathrm{C}$ & + & + & - & - & + & + & + & - & + & + & - & \pm & + & + \\
\hline $\mathrm{D}$ & + & - & $(+)$ & - & - & + & + & + & + & + & - & - & + & + \\
\hline$E$ & + & - & - & $(+)$ & - & + & + & + & - & + & - & - & . & + \\
\hline \multicolumn{15}{|c|}{$\begin{array}{l}+ \text { produzido por alguns tipos } \\
\text { - não conhecida a produção } \\
(+) \text { protoxina, requer ativação por enzimas } \\
\pm \text { existência questionada } \\
\text { não estudada } \\
\text { en enterotoxina } \\
\mathrm{nm} \text { neuraminidase }\end{array}$} \\
\hline
\end{tabular}


Toxina alfa $(\alpha)$

É produzida por todos os tipos de $C$. perfringens. De acordo com GLENNY e cols. (1933) esta toxina é hemolitica, dermonecrótica e letal. Sua produção pode ser obtida com poucas horas de cultivo em meio contendo peptona e carne (DALLING \& ROSS, 1938). Pode-se demonstrar "in vitro" a presença desta toxina por hemólise ou da precipitação da lecitina de ovo (OAKLEY, 1943; OAKLEY \& WARRACK, 1953; WILLIS, 1969; SMITH, 1975). Seus efeitos podem ser evidenciados, "in vivo", empregando-se as mais diversas vias de inoculação: letalidade, pelas vias endovenosa (GLENNY e cols., 1933; OAKLEY \& WARRACK, 1953) e intraperitoneal (DOWELL \& HAWKINS, 1974; SMITH, 1975) em camundongos e dermonecrose, por via intradérmica em cobaias (OAKLEY \& WARRACK, 1953; SMITH, 1975).

Toxina beta $(\beta)$

Esta toxina, possui atividades letal e dermonecrótica e é produzida somente pelos tipos B e C. De acordo com SMITH (1975) a obtenção desta toxina é máxima com 4 a 5 horas de incubação, em meio contendo pedaços de carne cortada ou moida. É termolábil a $50^{\circ} \mathrm{C}$ por 5 minutos, perdendo $75 \%$ de sua atividade e é inativada por tripsina a $37^{\circ} \mathrm{C}$ por 30 minutos (DOWELL \& HAWKINS, 1974; SMITH, 1975).

Toxina épsilon $(\varepsilon)$

É produzida pelos tipos B e D. Sua presença só pode ser demonstrada após tripsinização, uma vez que se apresenta na forma de protoxina (OAKLEY \& WARRACK, 1953). Tem ação letal e necrotizante (ROOD \& COLE, 1991). Em inoculação por via intradérmica em cobaias, produz lesões características 
(WARRACK, 1963). Sua produção máxima pode ser observada, segundo o meio de cultivo, entre 3 e 5 dias (GLENNY e cols., 1933) ou 5 a 7 horas (PIVNICK e cols., 1965) de incubação a $37^{\circ} \mathrm{C}$.

Toxina iota ( 1 )

Esta toxina é produzida como protoxina necessitando, portanto, de ativação pela tripsina. CRAIG \& MILES (1961) determinaram sua presença em cultivos de $C$. perfringens do tipo $E$, após 4 horas a $37^{\circ} \mathrm{C}$ e, segundo OAKLEY \& WARRACK (1953), ela pode ser evidenciada pelos testes de letalidade por via endovenosa em camundongos e de dermonecrose por via intradérmica em cobaias.

Toxina delta $(\delta)$

É produzida pelos tipos B e C, sendo sensivel, quando exposta ao ar, e termo-estável, pois a $100^{\circ} \mathrm{C}$ por 10 minutos mantém $45 \%$ de sua atividade. É destruida por tripsina em 1 a 2 horas a $37^{\circ} \mathrm{C}$ e possui atividade hemolítica sobre hemácias de caprinos, ovinos, suínos e bovinos. Hemácias de camundongos, eqüinos, cobaias, coelhos e homem, não são lisadas por esta toxina (OAKLEY \& WARRACK, 1941).

Toxina teta $(\theta)$

É uma hemolisina que apresenta atividade letal (GALE \& VAN HEYNINGEN, 1942; YAMAKAWA e cols., 1977), é inativada quando exposta ao ar e ao aquecimento (VAN HEYNINGEN, 1941). A produção máxima desta toxina ocorre após 5 horas de incubação a $37^{\circ} \mathrm{C}$, sendo maior em meios contendo 
glicose. Lisa hemácias humanas, de ovinos, bovinos, leporinos, eqüinos, caprinos, suínos, felinos e de cobaias, porém é pouco ativa sobre hemácias de camundongos (OAKLEY \& WARRACK, 1941). Esta hemolisina é produzida por todos os tipos de $C$. perfringens sendo, entretanto, produzida em pequena quantidade por amostras do tipo $\mathrm{A}$, responsáveis por toxinfecção alimentar, e não produzida pelas do tipo $\mathrm{C}$, causadoras de enterite necrótica no homem (BROOKS e cols., 1957). Para sua produção recomenda-se a adição de hemácias de eqüinos no meio de cultivo (EVANS, 1945).

Toxinas lambda $(\lambda)$ e capa $(\kappa)$

Estudos realizados por OAKLEY e cols., (1948) determinaram a presença de duas toxinas em filtrados de cultura de $C$. perfringens.

Uma das substâncias, produzida por cepas dos tipos $B, D$ e $E$, não atuava no colágeno integro mas hidrolisava a gelatina e também agia sobre a caseina. Esta substância antigênica denominada toxina lambda $(\lambda)$, constitui uma proteinase que é completamente inativada por pepsina, apresentando atividade ótima em pH entre 6,0 e 7,5 (BIDWELL, 1950; PIVNICK e cols., 1965). É termolábil e inibida em presença de cisteína e citrato (BIDWELL, 1950).

A outra substância, a toxina capa ( $\kappa)$, causava a destruição do colágeno, por inoculação pelas vias intradérmica e intramuscular em cobaias e endovenosa em camundongos, sendo, portanto, considerada uma colagenase. Sua produção foi determinada em organismos dos tipos $A, C$ e $E$ e alguns do tipo $D$, porém, não nos do tipo B (OAKLEY e cols., 1948), excetuando-se as isoladas no Irã (BROOKS \& ENTESSAR, 1957). Verificou-se ainda que a presença da enzima capa (к) só podia ser evidenciada após a neutralização da enzima lambda $(\lambda)$ (PIVNICK e cols., 1964). 
Toxina mi $(\mu)$

MCCLEAN (1936), inoculando filtrados de cultura por via intradérmica em cavalos, verificou a presença de um antígeno que produzia o aumento da permeabilidade tecidual. Anos depois, CHAIN \& DUTHIE (1940) caracterizaram esta substância como uma hialuronidase denominada, cerca de uma década mais tarde, antígeno mi $(\mu)$ (OAKLEY \& WARRACK 1951).

Esta enzima é termolábil, inativada rapidamente em temperatura superior a $50^{\circ} \mathrm{C}$ e sua atividade ótima se dá em $\mathrm{pH} 6,0$, sendo ativada por citratos, fosfatos, cloretos e sulfatos (ROBERTSON e cols., 1940; McCLEAN \& ROGERS, 1943; ROGERS, 1948). Sua produção é obtida em culturas a partir de 5 horas a $37^{\circ} \mathrm{C}$, atingindo alta concentração após 18 horas (ROBERTSON e cols., 1940). A adição de glicose (GALE \& VAN HEYNINGEN, 1942) bem como de carne ao meio de cultivo, favorece sua produção (OAKLEY \& WARRACK, 1951; BROOKS e cols., 1957). A hialuronidase, produzida pelas cepas dos tipos A, B, C, D e E (ROBERTSON e cols., 1940; OAKLEY \& WARRACK, 1951; BROOKS e cols.,1957) e por apenas uma do tipo $C$ originária da espécie suina (BROOKS e cols., 1957) e não pelas do tipo $E$ (MCDONEL, 1980), é a responsável pelas irregularidades na forma das lesões dermonecróticas observadas por inoculação intradérmica em cobaias dos seus filtrados (OAKLEY \& WARRACK, 1953).

\section{Toxina ni $(v)$}

É uma desoxiribonuclease que OAKLEY \& WARRACK (1951) designaram como antígeno ni (v). De acordo com WILLIS (1969) esta enzima não tem atividade letal, necrótica e tampouco hemolítica. Porém os filtrados de cultivo de cepas que a produzem, provocam, "in vitro" e "in vivo", destruição dos leucócitos polimorfonucleares e das células musculares (ROBB-SMITH, 1945). É elaborada por todos os tipos de $C$. perfringens, embora não por todas as cepas (BROOKS e cols., 1957). 
Neuraminidase $(\mathrm{nm})$

É uma sialidase, enzima que cinde residuos do ácido acilneuramínico de oligossacarídeos, glicoproteinas, glicopeptídeos e ácido colonimico (CABEXAS, 1978). É produzida por cepas, de $C$. perfringens de todos os tipos (McCREA, 1947; COLLEE, 1965; FRASER \& COLLEE, 1975; FRASER, 1978).

O papel desta enzima nas doenças não está, ainda, bem definido, mas acredita-se que destrua os receptores da superfície celular rompendo o tecido conjuntivo (McDONEL, 1980, 1986).

Enterotoxina (en)

É uma proteina termolábil, pois a $60^{\circ} \mathrm{C}$ sua atividade biológica, "in vivo", é destruida em 5 minutos, embora a sorológica se mantenha por até 80 minutos (NAIK \& DUNCAN, 1978). Só é produzida por células em esporulação (DUNCAN \& STRONG, 1969; DUNCAN e cols., 1972) o que depende da composição do meio de cultura, incluindo carboidratos, $\mathrm{pH}$ e temperatura (LABBE \& DUNCAN, 1974, 1975). O pH, em valores de 1,0,3,0,5,0 e 12,0, determina a perda de sua atividade (DUNCAN \& STRONG, 1969). O tratamento com pronase e subtilisina a inativam, enquanto que, com tripsina, quimiotripsina, lipase, $\alpha$ amilase, papaina, bromelina, carboxipeptidase e neuraminidase sua atividade é mantida (DUNCAN \& STRONG, 1969; HAUSCHILD \& HILSHEIMER, 1971; ICMSF, 1996). No entanto estudo realizado por GRANUM e cols. (1981) demonstrou que sua atividade poderia ser aumentada em cerca de três vezes se tratada por tripsina. 
A produção de cada uma destas toxinas coincide com a multiplicação celular, porém com variações (GALE \& VAN HEYNINGEN, 1942). A maioria das toxinas e fatores solúveis produzidos por $C$. perfringens pode ser obtida na fase exponencial do crescimento, em meio de carne cozida, após 6 horas a $37^{\circ} \mathrm{C}$ (WILLIS, 1969), entretanto, segundo ISPOLATOVSKAYA (1971) a maior atividade biológica é obtida em cultivo, após 6 a 9 horas a $37^{\circ} \mathrm{C}$.

A fase de multiplicação celular interfere na produção de toxinas, porém são igualmente importantes a composição e $\mathrm{opH}$ do meio de cultivo (HAUSCHILD, 1971).

Toxina eta $(\eta)$

É letal e sua produção é atribuída a uma cepa de C. perfringens tipo A, amostra Lechien. Sua existência foi aventada quando se verificou que, para suprimir a ação letal havia a necessidade do uso de maior quantidade de antisoro, do que para inibir o efeito dermonecrótico (OAKLEY, 1943; HAUSCHILD, 1971). Porém, pelo fato de não ser produzida por todas as cepas e ser neutralizada por anti-soro do tipo A, sua ocorrência é questionável (HAUSCHILD, 1971; MCDONEL, 1986).

Toxina gama $(\gamma)$

Esta toxina foi descrita por GLENNY e cols., (1933) como um antígeno com atividade letal e acredita-se que seja produzida por cepas dos tipos B e C. No entanto há dúvidas com relação à sua existência, uma vez que nenhuma substância ativa foi isolada e purificada em culturas suspeitas (MCDONEL, 1980, 1986). 
Uma vez no lúmen intestinal, a enterotoxina se liga às células epiteliais, altera a configuração de alguns componentes da membrana celular causando mudanças estruturais e funcionais, responsáveis pela ocorrência de diarréia (MCDONEL, 1979, 1980; SHERMAN e cols., 1994).

Outras substâncias

Hemaglutininas (COLLEE, 1961; MEHTA \& NARAYAN, 1991; KULSHRESTHA \& GULRAJANI, 1972) fibrinolisina, fator estimulante da tireóide, pirogênio, fatores hemolíticos (não alfa, teta ou delta) e circulantes são outras substâncias passiveis de serem produzidas por cepas de $C$. perfringens cuja atividade e até mesmo existência são questionáveis (MCDONEL, 1980, 1986).

Os C. perfringens podem expressar treze tipos diferentes de toxinas e uma única célula pode produzir somente um grupo definido (MCDONEL, 1986).

Tipificação de $C$. perfringens

A classificação do C. perfringens nos tipos A, B, C, D e E, baseada nos antigenos major e estabelecida por WILSDON (1931), e ainda hoje acatada, tem como fator restritivo o emprego de animais de laboratório (ROSS e cols., 1949). Pelo fato dos ensaios com animais serem dispendiosos e de difícil execução, muitos estudos foram realizados com o intuito de delinear testes "in vitro" para a diferenciação de espécies, porém sem grande sucesso (ORR \& REED, 1940; HENDERSON, 1940).

Em 1953, OAKLEY \& WARRACK recomendavam a inoculação intradérmica em cobaias, uma vez que esses antígenos, além de serem letais produzem dermonecrose. 
Métodos de tipificação "in vitro": imunodifusão em gel (OAKLEY \& FULTHORPE, 1953; ORLANS \& JONES, 1958; ELLNER \& BOHAN, 1962) e hemaglutinação, foram tentados, mas abandonados face aos resultados insatisfatórios obtidos (WARRACK, 1963).

WARRACK (1963) confirmando um estudo feito na década anterior (OAKLEY \& WARRACK,1953), demonstrou a superioridade do teste na tipificação dos $C$. perfringens por características de lesão dermonecrótica em detrimento do teste de letalidade, embora tenha recomendado, em alguns casos, a associação de ambos.

DOWEL \& HAWKINS (1974) preconizavam, para a tipificação de cepas, a inoculação intraperitoneal de sobrenadantes de culturas em camundongos. Para o referido teste, que é uma prova de soro-neutralização, há a necessidade de se dispor de animais de laboratório e dos vários anti-soros tipoespecificos, fatos que representam dificuldades à sua utilização.

A identificação por anti-soros específicos é indicada, embora não permita, na maioria das vezes, a tipificação exata, como pode ser observado no Quadro 3 (MCDONEL, 1980).

Quadro 3. Neutralização das toxinas produzidas pelos tipos de C. perfringens, por anti-soros específicos (MCDONEL, 1980).

\begin{tabular}{cc}
\hline anti-soro tipo-especifico & Tipo neutralizado \\
\hline$A$ & $A$ \\
\hline$B$ & $A, B, C$ e D \\
\hline$C$ & $A \in C$ \\
\hline$D$ & $A \in D$ \\
\hline$E$ & $A \in E$ \\
\hline
\end{tabular}


A maioria das pequisas foi e continua sendo empregada no estudo do modo de ação da enterotoxina (GIUGLIANO e cols., 1983). Ensaios demonstrando as principais características biológicas da enterotoxina de $C$. perfringens foram delineadas em coelhos, com alça intestinal ligada (DUNCAN \& STRONG, 1969), porém outros trabalhos empregando a mesma técnica classificam-na de inconveniente por ser onerosa e pouco sensivel (STARK \& DUNCAN 1972; GENIGEORGIS e cols., 1973).

O ensaio mais prático para se determinar a atividade biológica talvez seja o da dermonecrose realizado por WARRACK (1963), HAUSCHILD (1970) e STARK \& DUNCAN (1971), cujos resultados podem ser obtidos entre 18 e 24 horas após inoculação intradérmica em cobaias ou coelhos. É mais sensivel, menos dispendiosa e de mais fácil execução do que o da alça ligada, além de revelar pequenas quantidades de toxina, da ordem de 0,25 a 0,5 unidades eritemais (UE). GENIGEORGIS e cols., (1973) obtiveram a detecção de 0,06 a $0,125 \mu \mathrm{g}$ de toxina, embora a curva linear dose-resposta tenha revelado faixa ótima, entre 0,5 - 2,0 EU (McDONEL, 1980).

Apesar das restrições, testes com animais são importantes porque evidenciam as propriedades biológicas das toxinas e, em alguns casos, dão oportunidade a respostas imunológicas, sendo indispensáveis para o cumprimento dos postulados de Koch. Entretanto, não são adequados para estudos epidemiológicos em larga escala e tampouco para a detecção rotineira de organismos toxigênicos. Assim, diferentes testes devem ser utilizados em estudos de $C$. perfringens cuja escolha vai depender dos objetivos.

Os ensaios sorológicos de imunodifusão (ELLNER \& BOHAN, 1962), contraimunoeletroforese (GIUGLIANO e cols., 1983; HOLLIDAY, 1985), radioimunoensaio e ELISA (BARTHOLOMEW \& STRINGER, 1983), resultaram em grandes avanços na detecção e estudo de toxinas. Embora, em alguns casos, permaneçam como métodos de escolha, falta-lhes a característica funcional dos ensaios biológicos específicos. Assim, os resultados dependem mais de 
estruturas físicas do que da atividade da toxina, além da disponibilidade dos antisoros. Os métodos de difusão simples e dupla, em gel, eletroimunodifusão e contraimunoeletroforese são menos sensiveis do que o teste de atividade citotóxica em células Vero (McCLANE \& McDONEL, 1979; McDONEL \& McCLANE 1979), o qual detecta quantidades de toxina da ordem de 0,2-2,0 $\mathrm{\mu g} / \mathrm{mL}$ (McDONEL \& McCLANE, 1981; STRINGER e cols., 1982). Concentrações diminutas como $0,001 \mu \mathrm{g} / \mathrm{mL}$ de enterotoxina também podem ser detectadas por hemaglutinação passiva reversa e radioimunoensaio (GIUGLIANO e cols., 1983). Anticorpos fluorescentes já foram igualmente utilizados para evidenciar a enterotoxina contida no interior de células (NIILO, 1977).

A tipificaçāo de $C$. perfringens por bacteriocinas foi introduzida por MAHONY (1974) que desenvolveu esquema de classificação empregando 10 delas. Em estudo posterior SCOTT \& MAHONY (1982) já preconizaram o uso de um total de 18, formado por algumas do esquema anterior e outras recém selecionadas. O método é simples e eficiente (MAHONY, 1979; SATIJA \& NARAYAN, 1980), porém os tipos podem variar com a época do ano e vários deles podem estar presentes simultaneamente, havendo por isto a necessidade de se estudar diferentes colônias (MAHONY \& SWANTEE, 1978).

A classificação de C. perfringens, segundo os tipos, por toxinas é um método importante na diferenciação de grupos ecologicamente significantes (STERN \& WARRACK, 1964), porém não é útil para subdivisões adicionais. É inconveniente para estudos de rotina pois emprega cerca de 75 anti-soros diferentes, para uma resolução de $77 \%$. Para amostras de origem alimentar, STRINGER e cols., (1982) apontam cerca de $30 \%$ de falha na tipificação por sorologia, enquanto que por bacteriocinas, consegue-se $100 \%$ de êxito na tipificação (STRINGER, 1980). Assim SCOTT \& MAHONY (1982) e WATSON, (1985) recomendaram para os que utilizam anti-soros, a complementação com bacteriocinas para cepas não sorotipáveis. 
A eletroforese em gel de poliacrilamida na presença de dodecil sulfato de sódio (SDS-PAGE) foi originalmente descrita por LAEMMLI (1970) e, a partir de então, a caracterização de microrganismos por esta técnica se intensificou. Estes trabalhos em bacteriologia se iniciaram em estudos com Escherichia coli (MILKMAN, 1973) e posteriormente abrangeram a maioria das bactérias incluindo os anaeróbios (STROM e cols., 1976; SWINDLEHURST e cols., 1977; POXTON \& BROWN, 1979).

Análises eletroforéticas de populações naturais de organismos diplóides, mostraram que esterases hidrolisam múltiplos substratos e são, em geral, bastantes variáveis (GILLESPIE \& LANGLEY, 1974). Em organismos haplóides porém, utilizam um único substrato, apresentando diversidade eletroforética que permite diferenciação específica e subsespecifica (GOULLET, 1981; GOULLET \& PICARD, 1984).

A análise eletroforética de enzimas bacterianas tem sido empregada para estudos taxonômicos, epidemiológicos e de genética de populações (SELANDER e cols., 1986; GOULLET \& PICARD, 1990). Estudos eletroforéticos de esterases podem diferenciar bactérias de uma mesma espécie (GOULLET \& PICARD, 1990), com base na mobilidade e no tipo de esterase, definido pela especificidade pelos substratos, além de auxiliar em investigaçōes epidemiológicas (PICARD \& GOULLET,1987). A técnica permite que se use os mesmos reagentes no estudo de outras bactérias, além do $C$. perfringens. Não demanda muito tempo e é superior à tipificação por anti-soros e bacteriocinas os quais nem sempre estão disponiveis (PONS e cols., 1993).

Enfermidades causadas pelo C. perfringens

Como os clostrídios são pouco invasivos, a sua patogenicidade é muito mais determinada pelas toxinas que produzem. $O C$. perfringens produz, pelo menos 12 diferentes antigenos solúveis ou toxinas e a maioria dos estudos 
enfoca os efeitos patológicos que estas provocam. Entretanto, não está ainda plenamente estabelecida a participação de cada uma delas na produção de lesões e nos quadros determinados por este agente, tanto no homem quanto nos animais (MCDONEL, 1980, 1986).

O C. perfringens e suas toxinas estão implicados em várias enfermidades: toxinfecção alimentar no homem (HOBBS e cols., 1953; ICMSF, 1996), septicemia associada ao pós-parto e pós-abortamento e infeç̧ões de feridas traumáticas (MACLENNAN, 1962), além de ocorrências menos freqüentes como artrite séptica (SCHILLER e cols., 1979), pneumonia, empiema (BAYER e cols., 1975), meningite (MACKAY e cols., 1971), úlcera de córnea (STERN e cols., 1979), mionecroses (MOHR e cols., 1978) e cistite (MALIWAM, 1979).

Várias formas de enterite aguda ou enterotoxemias fatais têm sido também relatadas atingindo diversas espécies animais, como ovinos e bovinos (ROSE \& EDGAR, 1936; MACRAE e cols., 1943; MACKAY e cols., 1971); suinos (ESTRADA e cols., 1989); cães (CARMAN, 1983) e eqüinos (NIILO, 1980). Morte súbita de ovinos, bovinos e caprinos tem sido igualmente atribuída ao $C$. perfringens (NIILO \& AVERY, 1963; STERN \& BATTY, 1975; BALDASSI, 1995).

A literatura registra para humanos, 567 surtos de toxinfecção alimentar no periodo de 1970/80 na Inglaterra (HATHEWAY, 1990) e 1 em 1995 (REGAN e cols., 1995). Nos Estados Unidos foram relatados 190 no período de 1973 a 1987 (BEAN \& GRIFFIN, 1990) e 1 em 1993 (CDC, 1994). Também na Inglaterra, LARSON \& BORRIELLO (1988) descreveram 50 casos de diarréia por C. perfringens não associados à ingestão de alimento.

Embora a ocorrência do $C$. perfringens, a freqüência dos tipos e de suas toxinas, já estejam bem estabelecidas, a literatura científica no âmbito do Brasil não apresenta dados sobre sua prevalência como causa de enfermidades em humanos e em animais. Na área da patologia humana, BRANDÃO (1980) tipificou 308 cepas isoladas de amostras de fezes e de solo, na região do Rio de 
Janeiro. BALDASSI e cols., (1988) trabalhando com amostras, de vários Estados, oriundas de bovinos com sintomatologia nervosa detectaram em 75 amostras, $20 \%$ de positividade, para a presença deste agente, no cérebro e $9 \%$ no figado.

Na Inglaterra, NIILO (1980) relatou a ocorrência e importância do C. perfringens em várias espécies suscetiveis, mas enfatizou que faltavam conhecimentos sobre a distribuição dos tipos e sua patogênese, diagnóstico e incidência. Ressaltou que mortes nos rebanhos representavam significante proporção nas perdas econômicas, ainda que muitos casos permanecessem não diagnosticados, em decorrência de dificuldades relacionadas ao diagnóstico, além de áreas onde o conhecimento era limitado. Apontou ainda, como problemas, 0 isolamento e identificação das cepas das várias espécies freqüentemente presentes no mesmo órgão ou carcaça, sucesso na determinação da patogenicidade e toxigenicidade em condiçōes de laboratório e correta interpretação dos resultados, reconhecimento clínico da infecção baseado em sinais e achados de necrópsia, histórico anterior e localização geográfica. Estes problemas quanto ao diagnóstico estão diretamente relacionados com a pesquisa, pois há falta de conhecimentos adequados nestas áreas.

Todos estes fatos, associados ao crescente número de isolamentos de C. perfringens na última década, levaram a procurar sua melhor caracterização, visando oferecer subsídios para o controle efetivo das enfermidades por ele determinadas, as quais dizimam rebanhos em todo o Brasil, constituindo-se assim em relevantes problemas em Saúde Pública e Saúde Animal por ocasionar sérios prejuizos econômicos ao produtor, à população e ao país. 


\section{OBJETIVOS}

$\mathrm{O}$ isolamento de grande número de cepas de bactérias anaeróbias, principalmente de $C$. perfringens, em amostras de casos clínicos, oriundas de bovinos levados a óbito e as dúvidas encontradas na caracterização destas cepas, unicamente por identificação bioquímica, justificam a padronização e introdução de outro teste para melhor classificá-las.

Assim, planejou-se a realizaçăo desta investigação que tem por objetivo estudar cepas identificadas bioquimicamente como $C$. perfringens, isoladas de amostras obtidas durante a necrópsia de bovinos, segundo a:

1. verificação da capacidade toxigênica das cepas isoladas;

2. verificação da influência dos exopolissacarídeos (EPS) na toxigenicidade das cepas isoladas;

3. tipificação das cepas isoladas de acordo com o perfil esterase-eletroforético e o ensaio imunoenzimático (ELISA); e,

4. comparação entre os perfis esterase-eletroforéticos de cepas isoladas e padrão, com virulência exaltada e não exaltada. 


\section{MATERIAL E MÉTODOS}

3.1. Isolamento e identificação de $C$. perfringens a partir de amostras de necrópsia de bovinos.

\subsubsection{Amostras analisadas}

De 187 amostras de necrópsia de 71 bovinos com suspeita clínica de clostridiose, analisados quanto à presença de anaeróbios, houve isolamento de 187 cepas de Clostridium spp, assim constituidas: 48 de fígado, 19 de baço, 25 de rim, 36 de conteúdo intestinal, 13 de conteúdo de rúmen, 11 de medula de osso metatarsiano, 9 de sangue, 2 de mama, 11 de sistema nervoso central, 8 de pulmão e 5 de músculo. Destas, 144 foram identificadas como $C$. perfringens. Do total de isolamentos de $C$. perfringens selecionou-se 89 cepas, cujas amostras eram provenientes dos Estados de São Paulo (65), Bahia (05), Minas Gerais (03), Mato Grosso (10), Mato Grosso do Sul (01), Distrito Federal (01), Goiás (01), Piaui (01), Pará (01) e Pernambuco (01) (Quadro 4). 
Quadro 4. Relação das cepas isoladas de C. perfringens de origem bovina, segundo a amostra de isolamento e região de procedência. S. Paulo, 1997.

\begin{tabular}{|c|c|c|c|c|c|}
\hline $\begin{array}{c}\text { Amostra } \\
n^{\circ}\end{array}$ & $\begin{array}{l}\text { amostra de } \\
\text { isolamento }\end{array}$ & Procedência & $\begin{array}{c}\text { Amostra } \\
n^{\circ}\end{array}$ & $\begin{array}{l}\text { amostra de } \\
\text { isolamento }\end{array}$ & Procedência \\
\hline 1 & sist. nervoso & Pres. Venceslau, SP & 46 & fígado & Capital, SP \\
\hline 2 & rim & Pres. Venceslau, SP & 47 & fígado & Campinas, SP \\
\hline 3 & figado & Prado, BA & 48 & rúmen & Campinas, SP \\
\hline 4 & rúmen & Prado, BA & 49 & intestino & Monte Mor, SP \\
\hline 5 & canela & Pindamonhangaba, SP & 50 & rúmen & Socorro, SP \\
\hline 6 & sist. nervoso & Săo Roque, SP & 51 & intestino & Rio Maria, PA \\
\hline 7 & sangue & Sarupiranga, SP & 52 & figado & São Paulo, SP \\
\hline 8 & rúmen & Sarupiranga, SP & 53 & pulmão & Valparaíso, SP \\
\hline 9 & intestino & Prado, BA & 54 & intestino & Jundiai, SP \\
\hline 10 & intestino & Iuiú, BA & 55 & figado & Campo Grande, MS \\
\hline 11 & figado & Belo Horizonte, MG & 56 & fígado & São Paulo, SP \\
\hline 12 & figado & luiú, BA & 57 & figado & Avai, SP \\
\hline 13 & fígado & Caiuá, SP & 58 & fígado & Itú, SP \\
\hline 14 & rim & Pirassununga, SP & 59 & figado & Campinas, SP \\
\hline 15 & rim & Paraguaçu Paulista, SP & 60 & rim & Pedra Preta, MT \\
\hline 16 & rúmen & Itú, SP & 61 & fígado & São Paulo, SP \\
\hline 17 & fígado & Itú, SP & 62 & sist. nervoso & Iguape, SP \\
\hline 18 & rim & Cuiabá, MT & 63 & intestino & Capāo Bonito, SP \\
\hline 19 & figado & Cuiabá, MT & 64 & pulmão & Recife, PE \\
\hline 20 & rúmen & Cuiabá, MT & 65 & figado & Monte Mor, SP \\
\hline 21 & sist. nervoso & Guarantã do Norte, MT & 66 & figado & Penápolis, SP \\
\hline 22 & figado & Sinop, MT & 67 & figado & Atibaia, SP \\
\hline 23 & figado & Bataguaçu, SP & 68 & canela & Brasilândia, SP \\
\hline 24 & rim & Bastos, SP & 69 & intestino & S.L. Paraitinga, SP \\
\hline 25 & canela & S. A. do Pinhal, SP & 70 & fígado & Buri, SP \\
\hline 26 & figado & Pirassununga, SP & 71 & canela & Itapeva, SP \\
\hline 27 & fígado & Paranaguá, $\mathrm{PI}$ & 72 & figado & Mogi Mirim, SP \\
\hline 28 & figado & Paulicéia, SP & 73 & sist. nervoso & Martinópolis, SP \\
\hline 29 & intestino & Brasilia, DF & 74 & rim & Salto do Céu, MT \\
\hline 30 & figado & Pres. Venceslau, SP & 75 & músculo & Pres. Venceslau, SP \\
\hline 31 & figado & Jacupiranga, SP & 76 & rim & Bariri, SP \\
\hline 32 & rim & S.J. da Boa Vista, SP & 77 & rim & Brag. Paulista, SP \\
\hline 33 & intestino & Rondonópolis, MT & 78 & rim & Pres. Prudente, SP \\
\hline 34 & intestino & Caiuá, SP & 79 & fígado & Rondonópolis, MT \\
\hline 35 & intestino & Inocência, SP & 80 & intestino & Mairinque, SP \\
\hline 36 & intestino & Avai, SP & 81 & fígado & Pariquera Açu, SP \\
\hline 37 & rim & Pres. Venceslau, SP & 82 & intestino & Mira Estrela, MG \\
\hline 38 & rim & Marilia, SP & 83 & intestino & Itapajipe, MG \\
\hline 39 & figado & Pres. Venceslau, SP & 84 & mama & Lins, SP \\
\hline 40 & fígado & Sertãozinho, SP & 85 & intestino & Rondonópolis, MT \\
\hline 41 & baço & Marabá Paulista, SP & 86 & sangue & Tuiuti, SP \\
\hline 42 & rim & Luisiânia, GO & 87 & intestino & Tuiuti, SP \\
\hline 43 & figado & Capital, SP & 88 & mama & Guaiçara, SP \\
\hline 44 & baço & Inocência, SP & 89 & intestino & Ribeirão Branco, SP \\
\hline 45 & fígado & Ocauçú, SP & & & \\
\hline
\end{tabular}


As amostras, acondicionadas em caixas isotérmicas contendo gelo, eram encaminhadas ao laboratório da Seção de Bacteriologia Animal do Instituto Biológico da Secretaria de Agricultura e Abastecimento do Estado de São Paulo por portadores ou por transportadoras aéreas ou terrestres.

\subsubsection{Isolamento e identificaçăo bioquímica de $C$. perfringens nas amostras oriundas do campo}

As amostras sólidas, em fraçōes de 2,0 gramas cada, eram trituradas com pistilo de porcelana em gral contendo areia esterilizada. Após a trituração cerca de $0,5 \mathrm{~mL}$ do líqüido obtido era transferido para caldo de carne cozida (CCC), em tubos, preparado no próprio laboratório e previamente aquecido em banho-maria fervente por 10 minutos e resfriado rapidamente (regeneração). As demais amostras, sangue em volume aproximado de $1,0 \mathrm{~mL}$, os conteúdos intestinal e ruminal, cerca de $1,0 \mathrm{~g}$ e a medula óssea (osso metatarsiano), em quantidade equivalente a $1,0 \mathrm{~g}$, que não necessitavam passar por processo de trituração, eram colocadas diretamente no meio de cultura regenerado. Estes tubos eram mantidos em estufa por 24 - 48 horas a $37^{\circ} \mathrm{C}$. Deste cultivo um volume correspondente a uma alça de níquel-cromo, de $3,0 \mathrm{~mm}$ de diâmetro, era estriado em placa contendo ágar sangue de carneiro a $5 \%$, incubada em condições de anaerobiose em jarras de Mclntosh \& Fields, a $37^{\circ} \mathrm{C}$, por $18-24$ horas.

Após a incubação as colônias eram observadas com relação ao aspecto, coloração, presença e tipo de hemólise e a morfologia bacteriana era verificada microscopicamente em esfregaços corados pelo método de Gram. Colônias que se apresentavam como bacilos Gram-positivos eram isoladas e semeadas em CCC, o qual era incubado a $37^{\circ} \mathrm{C}$, por $18-24$ horas.

Estas culturas eram submetidas às seguintes provas bioquímicas complementares para identificação da espécie: produção de catalase, lecitinase, gelatinase e fermentação da glicose, lactose e leite desnatado. A interpretação 
destas provas era feita segundo HOLDEMAN \& MOORE (1972); MAHONY \& SWANTEE (1978); MAHONY e cols., (1992).

As cepas identificadas bioquimicamente como $C$. perfringens eram inoculadas em CCC, e após 18 - 24 horas de incubação a $37^{\circ} \mathrm{C}$, o cultivo era estocado a $4^{\circ} \mathrm{C}$ para posterior realização das provas de toxigenicidade, ELISA, eletroforese e extração de exopolissacarideos (EPS).

\subsubsection{Cepas de teste e padrão utilizadas}

Dentre as amostras positivas foram selecionadas 89 cepas de C. perfringens sendo 33 de fígado, 18 de conteúdo intestinal, 14 de rim, 6 de conteúdo de rúmen, 5 de sistema nervoso central, 4 de medula de osso metatarsiano, 2 de mama, 2 de sangue, 2 de baço, 2 de pulmão e 1 de músculo.

Além destas, eram empregadas como controle positivo, quatro cepas de $C$. perfringens do American Type Culture Collection (ATCC) a saber: ATCC 3624 (tipo A), ATCC 3626 (tipo B), ATCC 3628 (tipo C) e ATCC 3629 (tipo D).

Todas as cepas isoladas e padrão, eram cultivadas em CCC a $37^{\circ} \mathrm{C}$ por 18 -24 horas e, posteriormente, mantidas a $4^{\circ} \mathrm{C}$.

\subsection{Cultivo das cepas isoladas e padrão}

Cada cepa, isolada e padrão, era inoculada para um tubo contendo CCC, seguido de incubação a $37^{\circ} \mathrm{C}$ por 18 - 24 horas.

A partir de cada cultivo era semeada uma placa de ágar sangue de carneiro a $5 \%$ e incubada em condiçōes de anaerobiose em jarras de Mclntosh \& Fields, a $37^{\circ} \mathrm{C}$ por $18-24$ horas. Do crescimento obtido eram transferidas 5 
colônias (MAHONY e cols., 1992) para um tubo contendo $10 \mathrm{~mL}$ de caldo triptose-extrato de levedura (CTE), seguido de incubação nas mesmas condições descritas para placa. Após a incubação todo o volume de cada tubo era transferido para um frasco, contendo $90 \mathrm{~mL}$ do mesmo meio, o qual era incubado nas mesmas condições descritas (PONS e cols., 1993). Em todas as etapas era realizada a observação da morfologia bacteriana e pureza em esfregaços das culturas em lâminas, corados pelo método de Gram.

A cultura final era então submetida à centrifugação a $7.500 x g$ a $4^{\circ} \mathrm{C}$ por 15 minutos. $O$ sobrenadante era decantado e utilizado para o teste de toxigenicidade e extração de exopolissacarídeos. O sedimento obtido (massa celular) era lavado adicionando-se $100 \mathrm{~mL}$ de solução tampão tris-glicina $60 \mathrm{mM}, \mathrm{pH} \mathrm{8,7}$, seguido de nova centrifugação a $10.000 \times$ a $4^{\circ} \mathrm{C}$ por 10 minutos (PONS e cols., 1993). A massa obtida (sedimento) era suspensa em $1,0 \mathrm{~mL}$ do mesmo tampão, triturada com pistilo de porcelana em gral contendo nitrogênio líquido e, depois, novamente centrifugada a $10.000 \times g$, a $4^{\circ} \mathrm{C}$, por 30 minutos para remoção dos debris celulares $(B A C H, 1991)$. Do sedimento desta última centrifugação, de todas as cepas isoladas e padrão, eram tomadas aliquotas de cerca de $1 \mathrm{~mL} e$ mantidas em microtubos de $1,5 \mathrm{~mL}$ a $-20^{\circ} \mathrm{C}$ até o momento da realização das provas de ELISA e eletroforese.

\subsubsection{Determinação da toxigenicidade das cepas isoladas e padrăo (segundo BALDASSI, 1986)}

Um volume de $20 \mathrm{~mL}$ do sobrenadante obtido da cultura de cada cepa, isolada e padrão, obtido em 3.2., primeira centrifugação, era inoculado em dez camundongos brancos com peso entre 20 e $25 \mathrm{~g}$ na dose de 0,5 mL, por via intra peritoneal (VIP). Em cinco deles era injetado o sobrenadante puro e nos demais o sobrenadante tratado com tripsina, na concentração final de $1 \%$ e incubado a $37^{\circ} \mathrm{C}$ por 30 minutos. Os animais inoculados eram mantidos em observação por até 96 horas e as manifestações clínicas, bem como morte, eram registradas. 


\subsubsection{Extração dos exopolissacarídeos (EPS)}

Um volume de $50 \mathrm{~mL}$ do sobrenadante da cultura de cada cepa, isolada e padrão, obtida em 3.2., primeira centrifugação, era concentrado por meio da desidratação, em liofilizador (CHRISS, modelo Delta 1A), até a completa redução do liquido. Este concentrado era precipitado com etanol $95 \%$, adicionado a uma concentração final de $75 \%$ e mantido por 24 horas a $4^{\circ} \mathrm{C}$. A mistura era centrifugada a $3.000 \times$ por 10 minutos e, após a decantação, o sedimento era mantido em estufa a $40^{\circ} \mathrm{C}$ até a total evaporação do etanol, quando então eram adicionados $2,5 \mathrm{~mL}$ de água destilada esterilizada. Esta suspensão era empregada na estimativa da concentração de carboidratos (DISCHE, 1965) e de proteinas (BRADFORD, 1976) e em testes de toxigenicidade para camundongos (BALDASSI, 1986).

\subsubsection{Estimativa da concentração de carboidratos nos extratos de EPS (segundo DISCHE, 1965)}

Para a estimativa da concentração de carboidratos nos extratos de EPS, a um volume de $0,2 \mathrm{~mL}$ da suspensão correspondente a cada cepa, obtida em 3.2.2., era adicionado $0,1 \mathrm{~mL}$ de solução de antrona a $1 \%$. A mistura, após agitação em agitador elétrico para tubos (Ética, modelo 117), era colocada em banho de gelo, acrescida de $1,0 \mathrm{~mL}$ de ácido sulfúrico concentrado e mantida em banho-maria a $40^{\circ} \mathrm{C}$ por 2 horas e trinta minutos. A leitura do teste, feita por densidade óptica, era realizada em espectrofotômetro (Pye Unicam), utilizandose filtro de $620 \mathrm{~nm}$.

Empregou-se como parâmetro para os testes, uma curva preparada a partir de soluções padrão de glicose nas concentrações de 63,125 e $250 \mathrm{mg} / \mathrm{mL}$. 


\subsubsection{Estimativa da concentração de proteínas nos extratos de EPS (segundo BRADFORD, 1976)}

A concentração estimada de proteinas nos extratos era determinada por microtécnica pelo método de Bradford (1976) utilizando-se albumina bovina $V$ como padrão, que é expressa em termos de equivalentes $\mu \mathrm{g}$ de soro albumina bovina (SAB) por $\mu \mathrm{L}$, comparando-se com curvas padrão de concentrações que variaram de 20 a $120 \mu \mathrm{g}$ de SAB, em função de suas respectivas absorbâncias, obtidas em leitor de microplacas (BIO-RAD, modelo 3550-UV) acoplado a computador, programa "microplate manager".

\subsubsection{Determinação da toxigenicidade nos extratos de EPS (segundo BALDASSI, 1986)}

A constatação da toxigenicidade era realizada pela inoculação em cinco camundongos brancos com peso entre 20 e $25 \mathrm{~g}$ na dose de 0,5 mL do extrato de EPS, por via intra peritoneal (VIP). Os animais eram mantidos em observação por 96 horas e as manifestaçōes clinicas, bem como morte, eram registradas.

\subsubsection{Eletroforese dos sedimentos em gel de poliacrilamida}

\subsubsection{Estimativa da concentração de proteinas}

A determinação da concentração de proteínas nos sedimentos obtidos em 3.2., era realizada segundo o método de Bradford (1976), descrito no item 3.2.2.2. 


\subsubsection{Montagem das placas}

As placas de vidro eram desengorduradas com algodão embebido em álcool etílico $95 \%$. A seguir, o espaçador de borracha em forma de "u" era acertado de modo a acompanhar o contorno da placa de acrílico com o molde dos poços. Uma outra placa de vidro era então sobreposta e ambas as placas presas com garras em toda a extensão do espaçador. As placas eram mantidas na posiçăo vertical, de forma que o lado sem o espaçador estivesse na parte superior para receber o gel. 0 gel era preparado e logo em seguida, colocado lentamente, na câmara formada pela montagem das placas, evitando-se, assim, a formação de bolhas. Após a polimerização do gel o sistema era vedado com parafilme e as placas mantidas a $4^{\circ} \mathrm{C}$ até o momento de serem usadas (máximo de 18 horas).

A placa de molde e o espaçador eram retirados e a placa de vidro com o gel era colocada em cuba horizontal contendo tampão tris-glicina $0,1 \mathrm{M}, \mathrm{pH} 8,2$. Em ambas as extremidades, de toda a extensão do gel, no sentido da corrida, eram colocadas duas tiras de papel Whatmann $n^{\circ} 3$ para servir de ponte.

\subsubsection{Aplicação dos sedimentos das cepas}

Os sedimentos da última centrifugação do cultivo das amostras (item 3.2.) eram aplicados em volume de $18 \mu \mathrm{L}$ e cada placa, com o gel, com 12 poços, recebia 11 amostras de teste. $O$ último poço, recebia o mesmo volume de solução de azul de bromofenol a $0,25 \%$, este utilizado como corante de frente, servindo como guia do tempo de corrida. 


\subsubsection{Voltagem e tempo de corrida}

As corridas eram realizadas, em temperatura de $4^{\circ} \mathrm{C}$ por 4 a 6 horas, inicialmente a $5 \mathrm{~mA}$ e após a saida das amostras dos poços a amperagem era regulada para $10 \mathrm{~mA}$. $O$ tempo de corrida era determinado pelo momento em que - corante marcador alcançava $5,0 \mathrm{~cm}$ de distância da linha dos poços (ROBINSON, 1966).

\subsubsection{Coloração das esterases}

Imediatamente após o término das corridas eletroforética, os géis eram colocados na solução corante de "Fast Blue", adicionada do substrato sintético $\alpha$ naftil acetato, por um periodo de 60 minutos. A solução corante era então retirada, os géis mantidos em água destilada $e$, trinta minutos antes da sua secagem, eram embebidos em solução secante.

\subsubsection{Análise densitométrica}

Os géis eram desidratados em secador de gel (BIO-RAD, modelo 583) por uma hora, respectivamente, em temperaturas de $60,65,70$ e $80^{\circ} \mathrm{C}$ para a secagem completa. Em seguida, eram submetidos a análise densitométrica em densitômetro (BIO-RAD, modelo GS-700) acoplado a um microcomputador e analisados pelo programa "Molecular Analyst".

\subsubsection{Teste sorológico dos sedimentos}

Para a classificaçăo das cepas de $C$. perfringens isoladas foi utilizado o método "Enzyme Linked Immunosorbent Assay", duplo-sanduíche (DAS-ELISA) 
VOLLER e cols., (1976), DOBOSCH (1984), com anti-soros preparados, em coelhos, contra as cepas padrão (ATCC) tipos A, B, C e D.

\subsubsection{Obtenção dos soros contra as cepas padrão (ATCC) tipos A, $B, C$ e $D$ de $C$. perfringens.}

O mesmo procedimento de cultivo e de retirada do meio, descrito no item 3.2.2., foi realizado com as cepas padrão para obtenção do inóculo de imunização.

Os sedimentos das culturas foram adicionados de $50 \mathrm{~mL}$ de solução de cloreto de sódio $0,85 \%$ esterilizada, seguido de centrifugação a $7.500 \times$ a $4^{\circ} \mathrm{C}$ por 10 minutos. Os sobrenadantes foram desprezados $\mathrm{e}$ os sedimentos resuspensos nesta solução salina de forma a obter uma turvação equivalente a, aproximadamente, $2,4 \times 10^{4}$ bactérias $/ \mathrm{mL}$ da escala de McFarland. Estas suspensões foram aquecidas em banho-maria fervente por 1 hora (BATTY \& WALKER, 1963). A seguir, volumes iguais destas suspensões e de adjuvante completo de Freund (Sigma) foram emulsionados e serviram de inóculo para imunização de coelhos.

Os animais, coelhos da raça Branca da Nova Zelândia pesando, aproximadamente, $2,5 \mathrm{~kg}$ foram imunizados com $0,5 \mathrm{~mL}$ dos inóculos nos linfonodos da região plantar das patas traseiras (OLIVEIRA, 1975). Trinta dias após a inoculação, estes animais foram sangrados por punção cardíaca para a obtenção dos diferentes anti-soros específicos (A, B, C e D). Previamente à imunização foi realizada uma sangria nos animais para obtenção do soro normal.

Os anti-soros foram adicionados de timerosal na concentração de 1:10.000, acondicionados em frascos e mantidos a $-20^{\circ} \mathrm{C}$ até o momento da sua utilização. 


\subsubsection{Ensaio imunoenzimático (DAS-ELISA)}

A estimativa do título de anticorpos anti-C. perfringens tipos $A, B, C$ e $D$, foi realizada em microplacas de poliestireno (Poly Sorp), de origem dinamarquesa.

O sedimento de cada cepa de teste isolada, obtido em 3.2., diluído em solução tampão de carbonato, $\mathrm{pH} 9,6$, foi colocado em 4 poços da placa, a qual foi mantida a $4^{\circ} \mathrm{C}$ por 24 horas. Decorrido este periodo a placa foi lavada 3 vezes com $200 \mu \mathrm{L}$ de tampão fosfato (PBS), pH 7,4; acrescido de 0,05\% de "Tween 20 ", para a eliminação dos antígenos não adsorvidos. A seguir, foram colocadas, para cada uma das cepas, $200 \mu \mathrm{L}$ de uma diluição 1:5, em água destilada esterilizada, de cada um dos quatro anti-soros, em poços correspondentes, sendo as placas incubadas a $37^{\circ} \mathrm{C}$ por 2 a 4 horas. Após este espaço de tempo, as placas foram lavadas novamente, da forma como foi descrita anteriormente. A seguir foram colocados em cada um dos poços $200 \mu \mathrm{L}$ do conjugado anti-lgG de coelho, marcado com fosfatase, produzido em carneiro (Sigma). As placas foram incubadas a $37^{\circ} \mathrm{C}$ por 2 a 4 horas, lavadas como já descrito e, a cada um dos poços, adicionados $200 \mu \mathrm{L}$ do tampão substrato. Após 30 minutos de incubação a $37^{\circ} \mathrm{C}$, a absorbância foi medida em leitor de ELISA (BIO-RAD, modelo 3550-UV) em comprimento de onda de $405 \mathrm{~nm}$, acoplado a computador com programa "Microplate manager". A reação foi interrompida pela adição de $200 \mu \mathrm{L}$ de $\mathrm{NaOH}$ 3M em cada um dos poços.

Para a otimização de alguns parâmetros para o teste, foram estudados os efeitos da concentração do antígenos e da diluiçăo do conjugado sobre a reação. Os antígenos foram analisados nas concentrações de 600, 300 e $150 \mu \mathrm{g}$ em equivalentes de $S A B / m L$ e o conjugado nas diluições de 1:5 e 1:10. Os resultados foram comparados com os dados do soro normal e dos reagentes como controles negativos (VOLLER e cols., 1976). 


\subsubsection{Exaltação de virulência das cepas}

As quatro cepas padrão e as dez cepas isoladas que apresentaram variação quanto a toxigenicidade, previamente e após a adição de tripsina, tiveram sua virulência exaltada segundo o método de LOGAN e cols., (1945). Estas cepas eram cultivadas em CCC e após $18-24$ horas de cultivo a $37^{\circ} \mathrm{C}$ inoculadas por via intramuscular (VIM), em cobaias, na face interna da coxa. Nestas era realizada uma incisão, com prévia assepsia, no músculo já lesado, e um fragmento deste cultivado em CCC. Eram realizadas passagens até que, um inóculo de $0,1 \mathrm{~mL}$ de um cultivo de 6 horas em CCC, matasse uma cobaia com peso entre 200 a 250 gramas em 24 horas. Os cultivos, com as cepas com a virulência exaltada, eram mantidos a $4^{\circ} \mathrm{C}$ e considerados próprios para utilização por até uma semana (LOGAN e cols., 1945).

Dentro deste período era realizado o mesmo procedimento descrito em 3.2.3. para execução da corrida eletroforética corada para esterase. A eletroforese era realizada com cepas com virulência não exaltada e exaltada, em paralelo, com 0 intuito de se verificar a ocorrência de variações nos perfis eletroforéticos. 


\section{RESULTADOS}

\subsection{Caracterização bioquímica das cepas}

A análise microbiológica das amostras de órgãos, oriundas de bovinos, permitiu o isolamento de 187 cepas de bactérias do gênero Clostridium. Destas, 144 foram identificadas bioquimicamente como C. perfringens, por produzirem de catalase, lecitinase, gelatinase, fermentarem a glicose, lactose e tumultuosamente leite desnatado. Oitenta e nove delas foram aleatoriamente selecionadas para realização dos ensaios.

Destas 89 cepas, $33(37,1 \%)$ foram isoladas de amostras de fígado, 18 $(20,2 \%)$ de conteúdo intestinal, $14(15,7 \%)$ de rim, $6(6,7 \%)$ de conteúdo de rúmen, $5(5,6 \%)$ de sistema nervoso central, 4 de medula de osso metatarsiano, 2 $(2,2 \%)$ de mama, $2(2,2 \%)$ de sangue, $2(2,2 \%)$ de baço, $2(2,2 \%)$ de pulmão e 1 $(1,1 \%)$ de fragmento de músculo (Quadro 4 ).

Em alguns casos clínicos foram estudadas mais de uma cepa, porque se obteve $o$ isolamento de $C$. perfringens em mais de um material examinado.

\subsection{Determinação da toxigenicidade}

Do total de 89 cepas testadas, apresentadas no Quadro 5, 51 (57,3\%) revelaram-se produtoras de toxina, uma vez que determinaram a morte dos camundongos inoculados com os sobrenadantes das culturas, em sua forma não tratada elou após o tratamento por tripsina. Assim, do total de cepas testadas, 14 $(15,7 \%)$ manifestaram toxigenicidade apenas quando o sobrenadante estava na forma não tratada, $8(9,0 \%)$ somente após tripsinização e $29(32,6 \%)$ em ambas as formas. Em $38(42,7 \%)$ cepas não foi observada a morte dos camundongos após a inoculação dos sobrenadantes, na sua forma não tratada e tratada, revelando, portanto, a sua atoxigenicidade. 
Quadro 5. Toxigenicidade das 89 cepas de teste de $C$. perfringens isoladas, de amostras de origem bovina, detectada em sobrenadantes de cultura não tripsinizados e tripsinizados. São Paulo, 1997.

\begin{tabular}{|c|c|c|c|c|c|}
\hline Amostra & $\begin{array}{c}\text { sobrenadante } \\
\text { não tripsinizado }\end{array}$ & $\begin{array}{r}\text { sobrenadante } \\
\text { tripsinizado }\end{array}$ & Amostra & $\begin{array}{c}\text { sobrenadante } \\
\text { não tripsinizado }\end{array}$ & $\begin{array}{l}\text { sobrenadante } \\
\text { tripsinizado }\end{array}$ \\
\hline l & + & + & 46 & - & - \\
\hline 2 & + & + & 47 & - & - \\
\hline 3 & - & - & 48 & + & - \\
\hline 4 & - & - & 49 & - & - \\
\hline 5 & + & + & 50 & - & - \\
\hline 6 & - & - & 51 & - & - \\
\hline 7 & + & - & 52 & - & - \\
\hline 8 & - & - & 53 & - & - \\
\hline 9 & - & - & 54 & - & - \\
\hline 10 & + & + & 55 & - & - \\
\hline 11 & - & + & 56 & - & - \\
\hline 12 & - & - & 57 & - & - \\
\hline 13 & + & + & 58 & - & - \\
\hline 14 & $t$ & + & 59 & + & - \\
\hline 15 & + & + & 60 & + & + \\
\hline 16 & + & + & 61 & - & - \\
\hline 17 & + & - & 62 & - & - \\
\hline 18 & + & - & 63 & + & - \\
\hline 19 & + & + & 64 & + & - \\
\hline 20 & - & - & 65 & - & + \\
\hline 21 & - & - & 66 & - & - \\
\hline 22 & + & + & 67 & + & - \\
\hline 23 & - & - & 68 & + & - \\
\hline 24 & + & + & 69 & + & - \\
\hline 25 & + & + & 70 & - & + \\
\hline 26 & + & - & 71 & + & + \\
\hline 27 & - & - & 72 & - & - \\
\hline 28 & + & + & 73 & - & - \\
\hline 29 & + & + & 74 & + & + \\
\hline 30 & + & + & 75 & + & + \\
\hline 31 & + & + & 76 & + & + \\
\hline 32 & - & - & 77 & - & - \\
\hline 33 & - & - & 78 & - & - \\
\hline 34 & + & + & 79 & - & - \\
\hline 35 & - & + & 80 & + & + \\
\hline 36 & + & + & 81 & - & - \\
\hline 37 & - & + & 82 & - & - \\
\hline 38 & + & + & 83 & - & - \\
\hline 39 & + & - & 84 & + & + \\
\hline 40 & + & - & 85 & - & - \\
\hline 41 & - & - & 86 & - & - \\
\hline 42 & + & + & 87 & $t$ & + \\
\hline 43 & - & + & 88 & - & + \\
\hline 44 & + & - & 89 & - & + \\
\hline 45 & + & + & 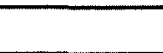 & & \\
\hline
\end{tabular}




\subsection{Extração de Exopolissacarídeos (EPS)}

Os valores das concentrações de proteina e de carboidratos bem como os resultados do teste de toxigenicidade, determinadas nos extratos de EPS, obtidos a partir das cepas isoladas, encontram-se distribuídos na Tabela 1.

Em relação a toxigenicidade dos 89 extratos de EPS, apenas $12(13,5 \%)$ foram responsáveis pela morte de camundongos. Porém, com 21 outros extratos observou-se que após a inoculação os camundongos apresentavam-se inertes, mas com respiração abdominal. Estes camundongos foram separados dos demais porque presumia-se que a morte seria a conseqüência natural, porém, surpreendentemente, 18 horas após estes animais estavam completamente recuperados.

O efeito da toxigenicidade foi então confrontado com as concentrações de carboidratos e proteínas determinadas nos mesmos extratos, verificando-se que os valores nos casos de morte dos camundongos, estavam entre 0,31 e $0,59 \mathrm{mg} / \mathrm{mL}$ para carboidratos e $0,04 \mathrm{mg} / \mathrm{mL}$ para proteínas.

Para proteinas, o menor valor encontrado foi $0,04 \mathrm{mg} / \mathrm{mL}$. O acima e mais próximo deste foi $0,05 \mathrm{mg} / \mathrm{mL}$ (cepas 30 e 31 ), mas os teores de carboidratos superavam o do intervalo de 0,31 a 0,59, determinado nas amostras toxigênicas.

A relação carboidrato/proteina não se revelou importante, pois os valores desta relação nos extratos que causaram a morte estavam contidos naqueles que não provocavam a morte dos camundongos. 
Tabela 1. Quantificação de carboidratos $(\mathrm{mg} / \mathrm{mL})$ e proteinas $(\mathrm{mg} / \mathrm{mL})$ e toxicidade para camundongos dos extratos de EPS de 89 cepas de Clostridium perfringens. São Paulo, 1997.

\begin{tabular}{|c|c|c|c|c|c|c|c|c|c|}
\hline Amostra & carb. & prot. & carb/prot. & tox. & Amostra & carb. & prot. & carb/prot. & tox. \\
\hline 1 & 0,53 & 0,04 & 13,25 & + & 46 & 3,64 & 0,07 & 52,00 & - \\
\hline 2 & 0,42 & 0,04 & 10,50 & + & 47 & 3,11 & 0,06 & 51,83 & - \\
\hline 3 & 1,91 & 0,34 & 5,62 & - & 48 & 2,74 & 0,10 & 27,40 & - \\
\hline 4 & 2,38 & 0,36 & 6,61 & - & 49 & 4,35 & 0,20 & 21,75 & - \\
\hline 5 & 1,72 & 0,30 & 5,73 & - & 50 & 2,90 & 0,18 & 16,11 & - \\
\hline 6 & 1,65 & 0,13 & 12,69 & - & 51 & 3,08 & 0,13 & 29,23 & - \\
\hline 7 & 2,74 & 0,28 & 9,78 & - & 52 & 1,35 & 0,20 & 6,75 & - \\
\hline 8 & 3,10 & 0.14 & 22,14 & - & 53 & 1,98 & 0,08 & 24,65 & - \\
\hline 9 & 2,80 & 0,13 & 21,54 & - & 54 & 2,05 & 0,11 & 18,63 & - \\
\hline 10 & 4,75 & 0,09 & 52,77 & - & 55 & 3,10 & 0,13 & 23,84 & - \\
\hline 11 & 4,05 & 0,30 & 13,50 & - & 56 & 1,00 & 0,30 & 3,33 & - \\
\hline 12 & 3,48 & 0,18 & 19,30 & - & 57 & 1,60 & 0,08 & 20,00 & - \\
\hline 13 & 1,83 & 0,06 & 30,50 & - & 58 & 1,85 & 0,10 & 18,50 & - \\
\hline 14 & 4,10 & 0,21 & 19,52 & - & 59 & 0,45 & 0,04 & 11,25 & + \\
\hline 15 & 1,15 & 0,18 & 6,38 & - & 60 & 3,10 & 0,15 & 20,66 & - \\
\hline 16 & 1,14 & 0,30 & 3,80 & - & 61 & 4,60 & 0,17 & 27,06 & - \\
\hline 17 & 4,16 & 0,10 & 41,60 & - & 62 & 2,80 & 0,16 & 17,50 & - \\
\hline 18 & 0,31 & 0,04 & 7,75 & + & 63 & 2,94 & 0,18 & 16,33 & - \\
\hline 19 & 0,59 & 0,04 & 14,75 & + & 64 & 0,48 & 0,04 & 12,00 & + \\
\hline 20 & 2,54 & 0,13 & 19,53 & - & 65 & 1,39 & 0,28 & 4,96 & - \\
\hline 21 & 2.21 & 0.06 & 36,83 & - & 66 & 1,86 & 0,00 & 0,00 & - \\
\hline 22 & 3,53 & 0,26 & 13,57 & - & 67 & 2,90 & 0,10 & 29,00 & - \\
\hline 23 & 2,56 & 0,10 & 25,60 & - & 68 & 1,30 & 0,09 & 14,44 & - \\
\hline 24 & 0,39 & 0,04 & 9,75 & + & 69 & 1,68 & 0,10 & 16,80 & - \\
\hline 25 & 1,96 & 0,09 & 21,77 & - & 70 & 1,84 & 0,26 & 7,07 & - \\
\hline 26 & 1,20 & 0,10 & 12,00 & - & 71 & 1,95 & 0,11 & 17,72 & - \\
\hline 27 & 3,20 & 0,10 & 32,00 & - & 72 & 3,10 & 0,22 & 14,09 & - \\
\hline 28 & 0,93 & 0,17 & 5,47 & - & 73 & 3,28 & 0,1 & 32,80 & - \\
\hline 29 & 0,58 & 0,04 & 14,50 & + & 74 & 0,45 & 0,04 & 11,25 & + \\
\hline 30 & 2.51 & 0,05 & 50,20 & - & 75 & 0,48 & 0,04 & 12,00 & + \\
\hline 31 & 3,22 & 0,05 & 64,40 & - & 76 & 0,55 & 0,04 & 13,75 & + \\
\hline 32 & 1,00 & 0,11 & 9,09 & - & 77 & 4,15 & 0,08 & 51,87 & - \\
\hline 33 & 1,54 & 0,06 & 25,66 & - & 78 & 4,40 & 0,08 & 55,00 & - \\
\hline 34 & 3,20 & 0,17 & 18,82 & - & 79 & 3,99 & 0,14 & 28,50 & - \\
\hline 35 & 0,93 & 0,10 & 9,30 & - & 80 & 0,95 & 0,18 & 5,27 & - \\
\hline 36 & 0,66 & 0,09 & 7,33 & - & 81 & 1,58 & 0,22 & 7,18 & - \\
\hline 37 & 4,23 & 0,21 & 20,14 & - & 82 & 2,01 & 0,09 & 22,00 & - \\
\hline 38 & 4,62 & 0,10 & 46,20 & - & 83 & 1,28 & 0,22 & 5,81 & - \\
\hline 39 & 4,67 & 0,08 & 58,37 & - & 84 & 3,32 & 0,23 & 14,43 & - \\
\hline 40 & 3,64 & 0,22 & 16,54 & - & 85 & 1,48 & 0,30 & 4,93 & - \\
\hline 41 & 1,96 & 0,06 & 32,36 & - & 86 & 1,03 & 0,25 & 4,12 & - \\
\hline 42 & 1,79 & 0,06 & 29,83 & - & 87 & 0,40 & 0,04 & 10,00 & + \\
\hline 43 & 1,47 & 0,18 & 8,16 & - & 88 & 1,70 & 0,29 & 5,86 & - \\
\hline 44 & 4,67 & 0,10 & 46,70 & - & 89 & 1,90 & 0,31 & 6,13 & - \\
\hline 45 & 2,86 & 0,22 & 13,00 & - & & & & & \\
\hline
\end{tabular}




\subsection{Caracterização e análise dos perfis eletroforéticos de esterase nos extratos bacterianos}

A análise e interpretação dos resultados foram feitas por três procedimentos: observação dos géis a olho nu, densitometria realizada por computador e comparação das densitometrias entre si.

O material resultante do rompimento das células bacterianas com nitrogênio líquido mostrou, na corrida eletroforética corada para esterase, uma ou no máximo duas bandas, com variação na quantidade de enzima produzida (largura das bandas no densitograma ou altura dos picos nos gráficos). As cepas padrão $A, B$ e $D$ apresentaram na densitometria de mobilidade eletroforética $(\mathrm{Rm})$, bandas entre 1,7 e $3,2 \mathrm{~cm}$, entre 3,0 e $4,8 \mathrm{~cm}$ e entre 2,5 e $6,0 \mathrm{~cm}$, respectivamente; o $C$ duas bandas, sendo uma entre 1,5 e $3,5 \mathrm{~cm}$ e a outra entre 3,5 e $5,4 \mathrm{~cm}$ distantes do ponto de aplicação (Figura 1).

Estabelecendo-se como parâmetros as $\mathrm{Rm}$ apresentadas pelas cepas padrão, foram classificadas as 89 cepas isoladas e selecionadas. A Figura 2 mostra, nos géis de poliacrilamida, as bandas referentes as corridas eletroforéticas coradas para esterase de duas cepas classificadas em cada um dos quatro tipos de $C$. perfringens e duas que não puderam ser identificadas em um tipo único. 


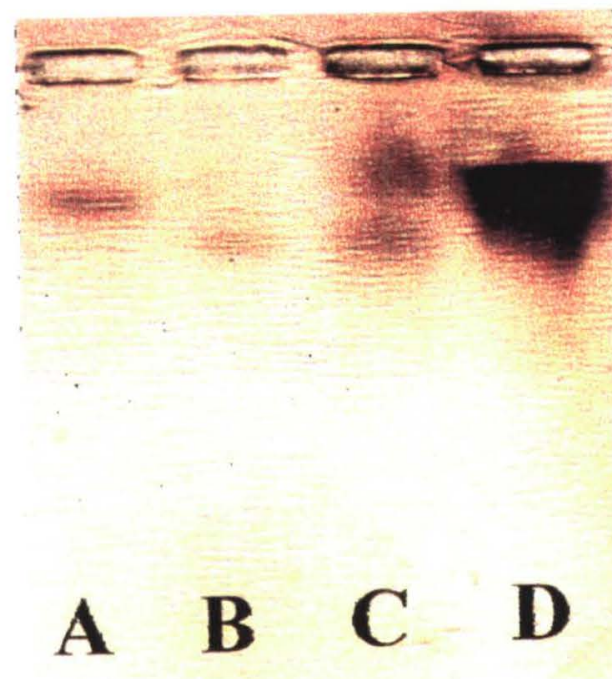

Figura 1. Densitometria do gel de poliacrilamida, corado para esterase, de corrida eletroforética de cepas de C. perfringens padrão ATCC 3624 tipo A, 3626 tipo B, 3628 tipo C e 3629 tipo D. São Paulo, 1997. 
A

$35 \quad 30$

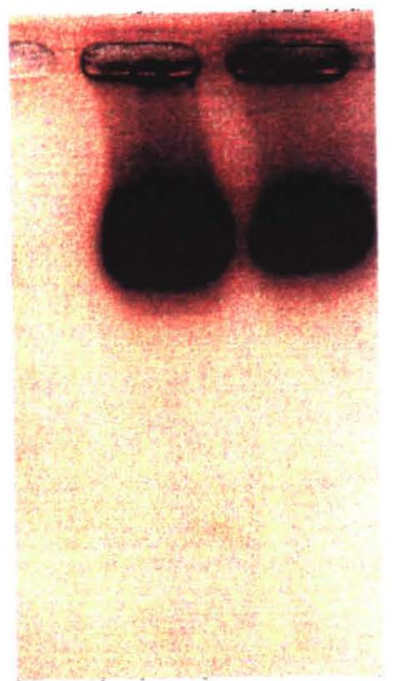

B

\section{$\begin{array}{ll}83 & 88\end{array}$}

$\Longrightarrow$

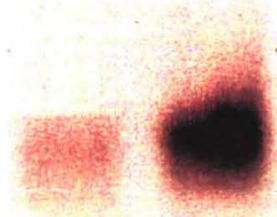

C

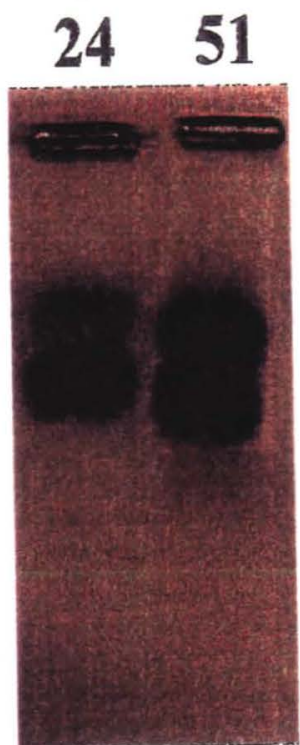

D

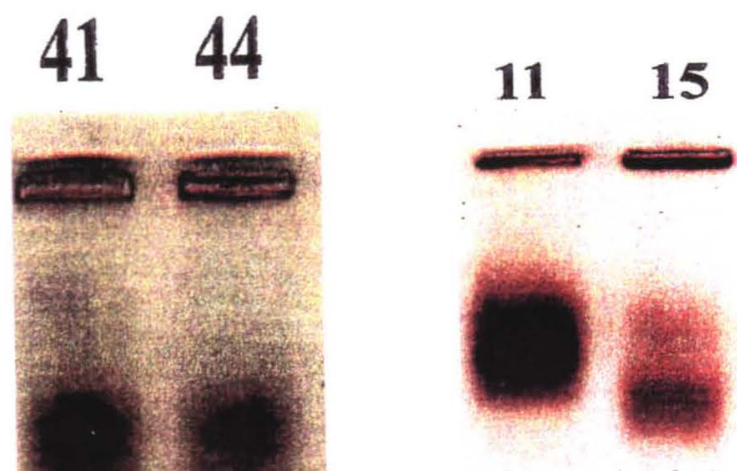

Figura 2. Densitometria do gel de poliacrilamida corad para esterase, de corrida eletroforética de 2 cepas de C. perfringens de teste isoladas, e identificadas para cada um dos tipos. São Paulo, 1997. 
A partir das corridas obteve-se ainda, em computador, os gráficos das densitometrias das cepas padrão e das isoladas selecionadas. A análise das densitometrias das cepas de teste, comparadas com as obtidas para as cepas padrão, confirmou a classificação prévia, nos vários tipos, pela simples observação das bandas. As Figuras 3, 4, 5 e 6 mostram a identidade de algumas cepas isoladas e selecionadas, respectivamente, com os tipos $A(1,9,48,75)$, $B(12,83,88), C(13,14,36,40)$ e $D(47,50,53,58)$.

Nas Figuras 7, 8, 9 e 10 são apresentados os densitogramas para as 89 cepas estudadas, classificando-as pelos tipos eletroforéticos (dendograma). Do total testado, $43(48,3 \%)$ das cepas foram classificadas como sendo do tipo A, 3 $(3,4 \%)$ do $B, 18(20,2 \%)$ do C, $20(22,5 \%)$ do D e $5(5,6 \%)$ não puderam ser agrupadas em um tipo único.

São mostradas na Tabela 2, as medidas da porcentagem do volume das bandas, sua área, média da absorbância e relação absorbância $x$ área nas corridas eletroforéticas, apresentadas pelas cepas padrão e das 89 de teste isoladas. Elas comprovam a existência de apenas uma banda para os padrões dos tipos $A, B$ e $D$ e as amostras de teste isoladas assim classificadas. Para o tipo C são apresentados dados referentes a duas bandas. Entretanto, outras amostras também apresentam duas bandas, não sendo reconhecidas como tipo C, por apresentarem valores de $\mathrm{Rm}$ diversos, indicando uma possivel presença de duas cepas diferentes. Os padrões $A, B$ e $D$ apresentaram somente uma banda com valores diferentes para a $\mathrm{Rm}$, não podendo assim, serem discriminados pelas atividades por apresentarem estes valores próximos ou mesmo iguais. 


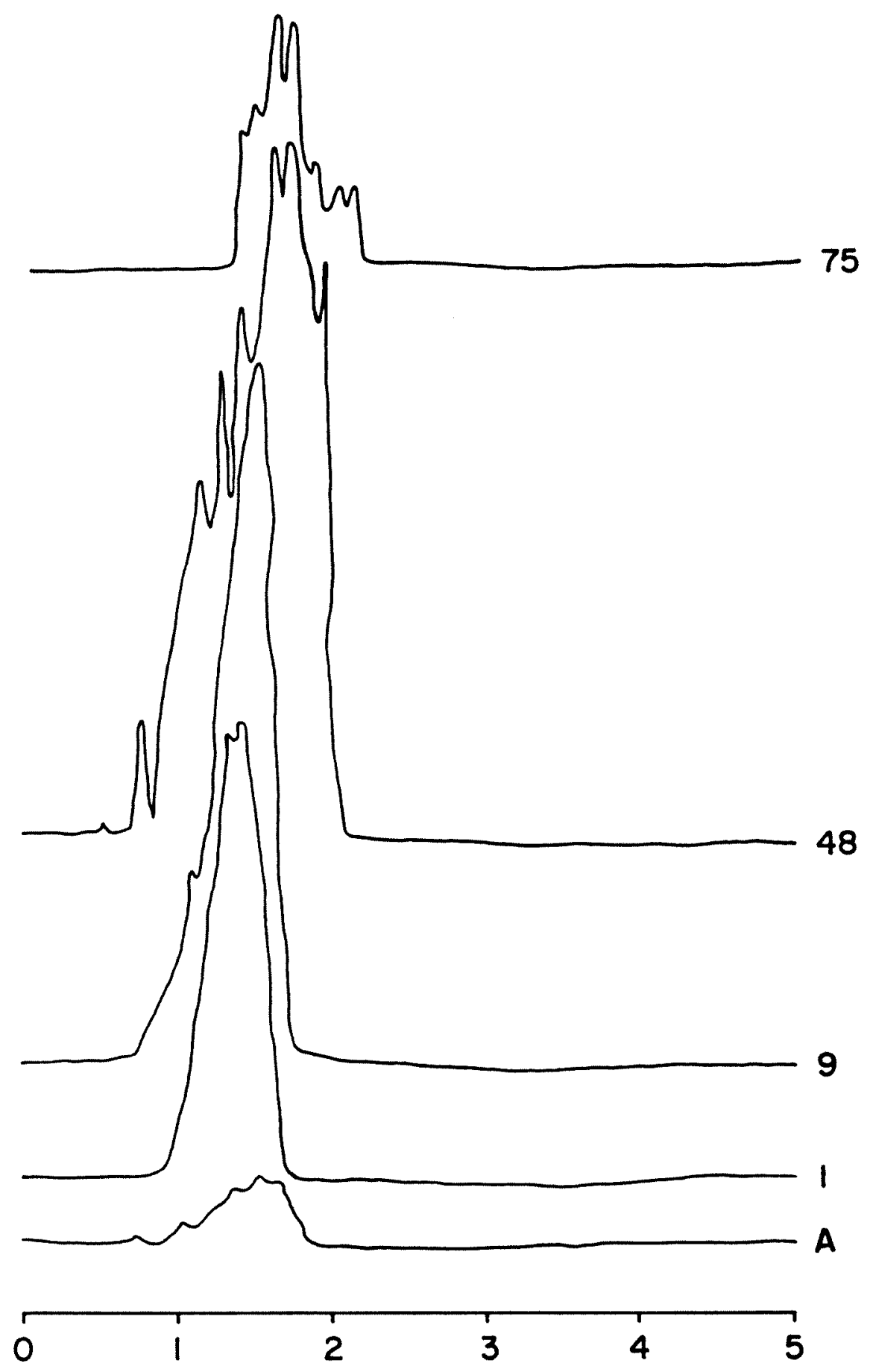

Figura 3. Gráfico da migração eletroforética de gel corado para esterase, de cepas de $C$. perfringens, padrão ATCC 3624, tipo A e de teste isoladas números 1, 9, 48, 75, São Paulo, 1997. 


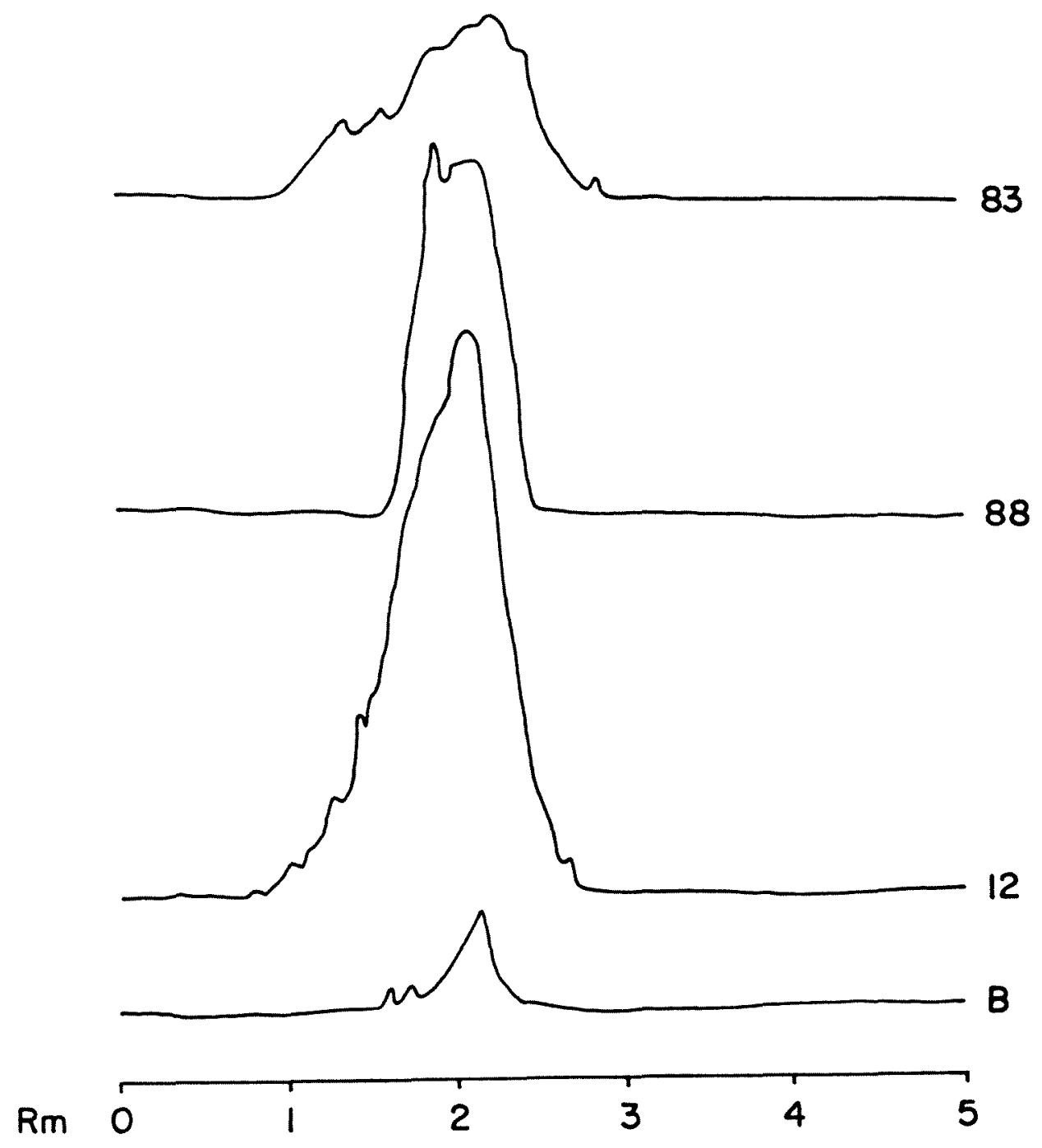

Figura 4. Gráfico da migração eletroforética, de gel corado para esterase, de cepas, de C. perfringens, padrão ATCC 3626 , tipo B e de teste isoladas números 12, 83 e 88. São Paulo, 1997. 


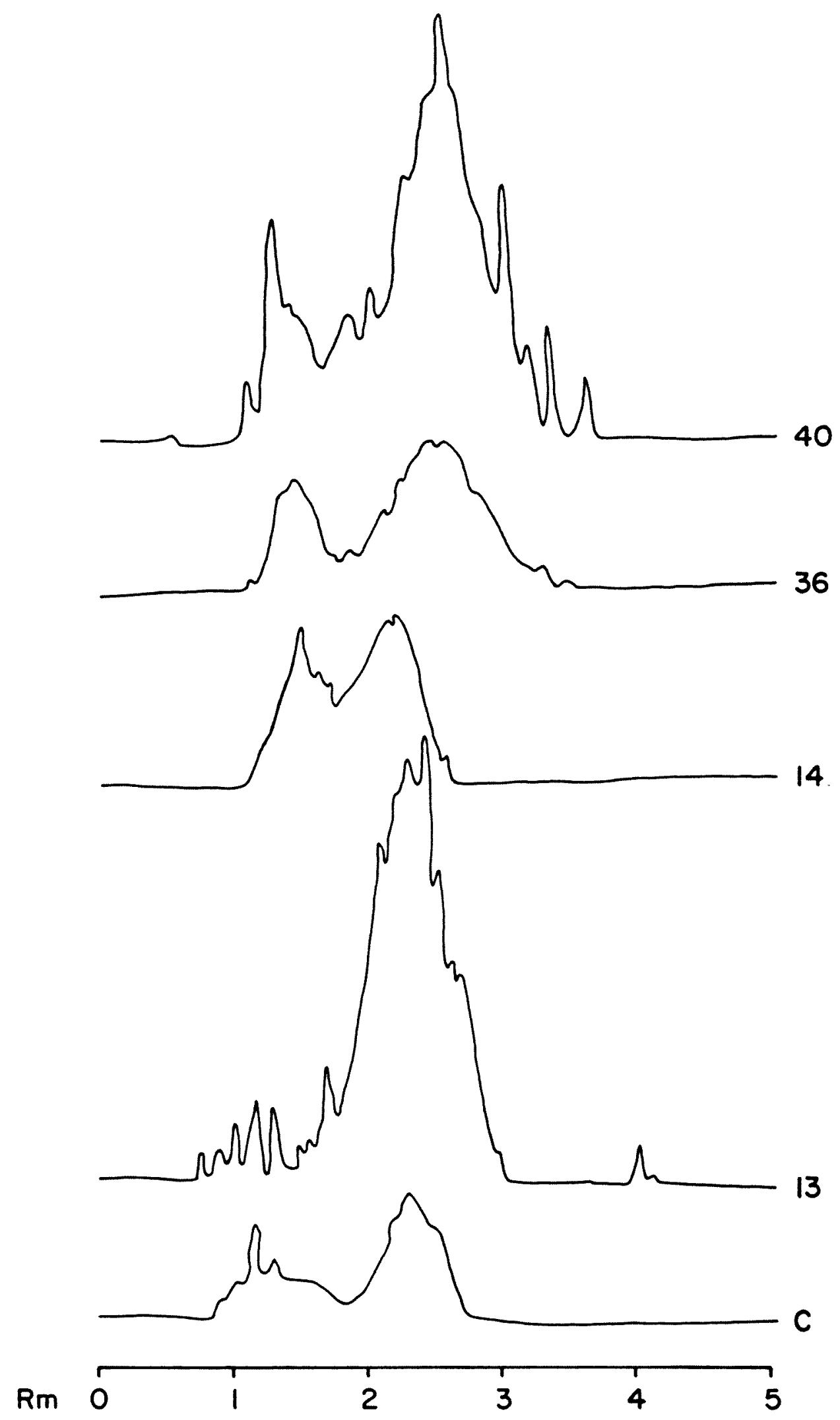

=igura 5. Gráfico da migração eletroforética, de gel corado para esterase, de cepas, de C. perfringens padrão ATCC 3628 , tipo $C$ e de teste isoladas números 13, 14, 36 e 40. São Paulo, 1997. 

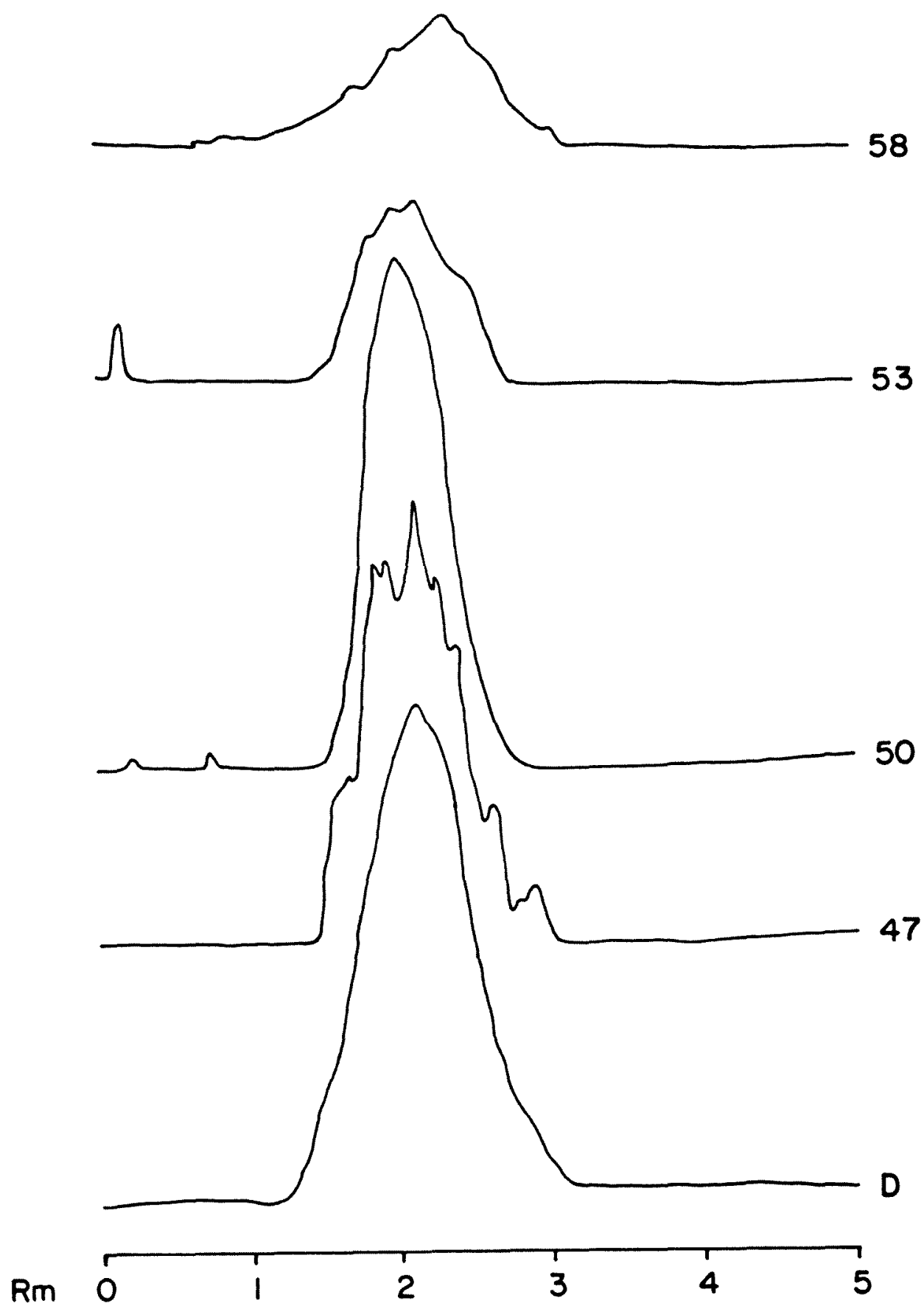

Figura 6. Gráfico da migração eletroforética, de gel corado para esterase, de cepas, de C. perfringens padrão ATCC 3629 , tipo D e de teste isoladas números 47, 50, 53 e 58. São Paulo, 1997. 


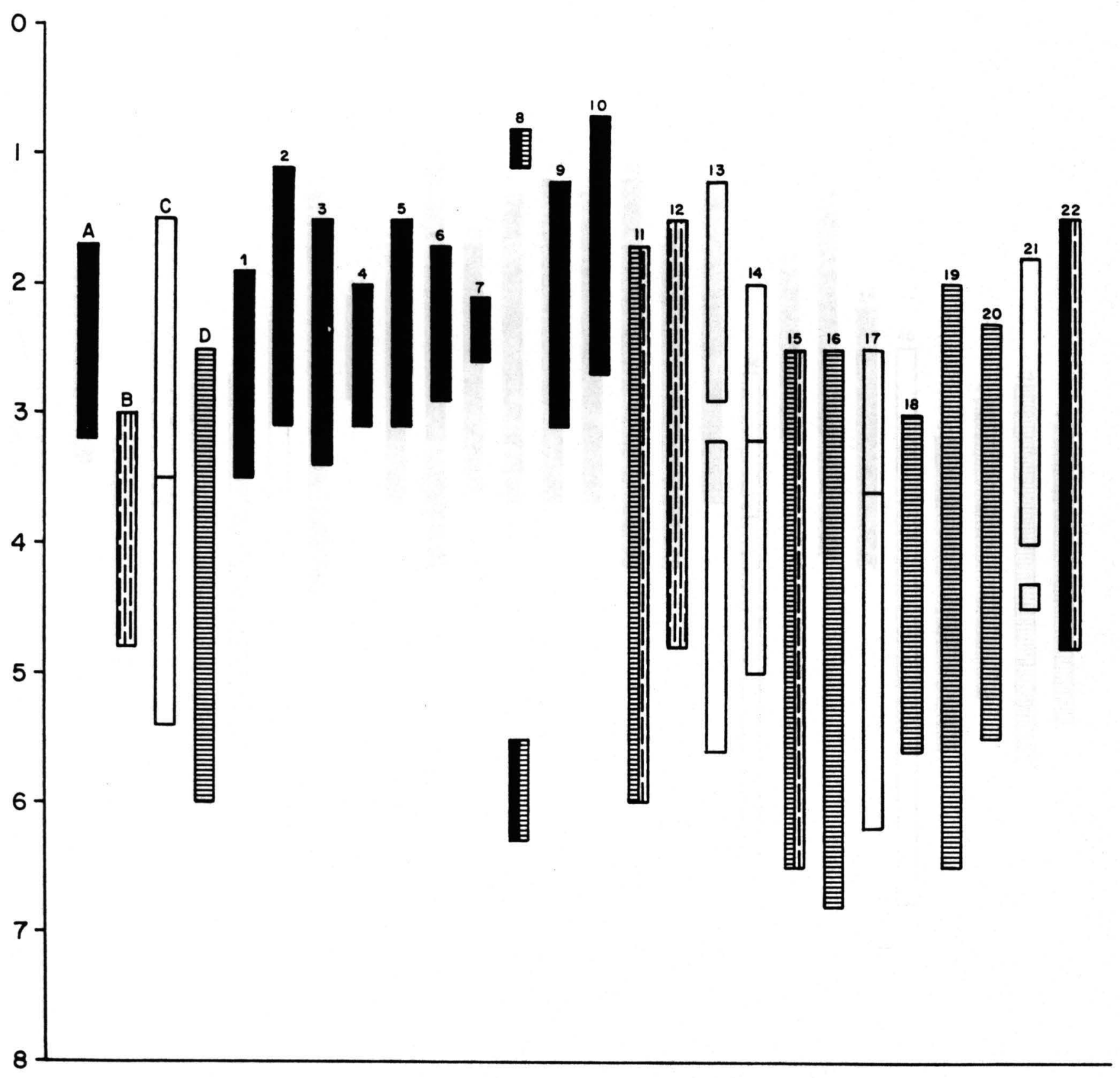

Figura 7. Dendograma da migração eletroforética das bandas de esterase, de acordo com a leitura densitométrica do gel de corrida das cepas de C. perfringens, padrão ATCC $3624,3626,3628$ e 3629 , respectivamente, tipos $A, B, C$ e $D$ e de 22 de teste isoladas. São Paulo, 1997. 


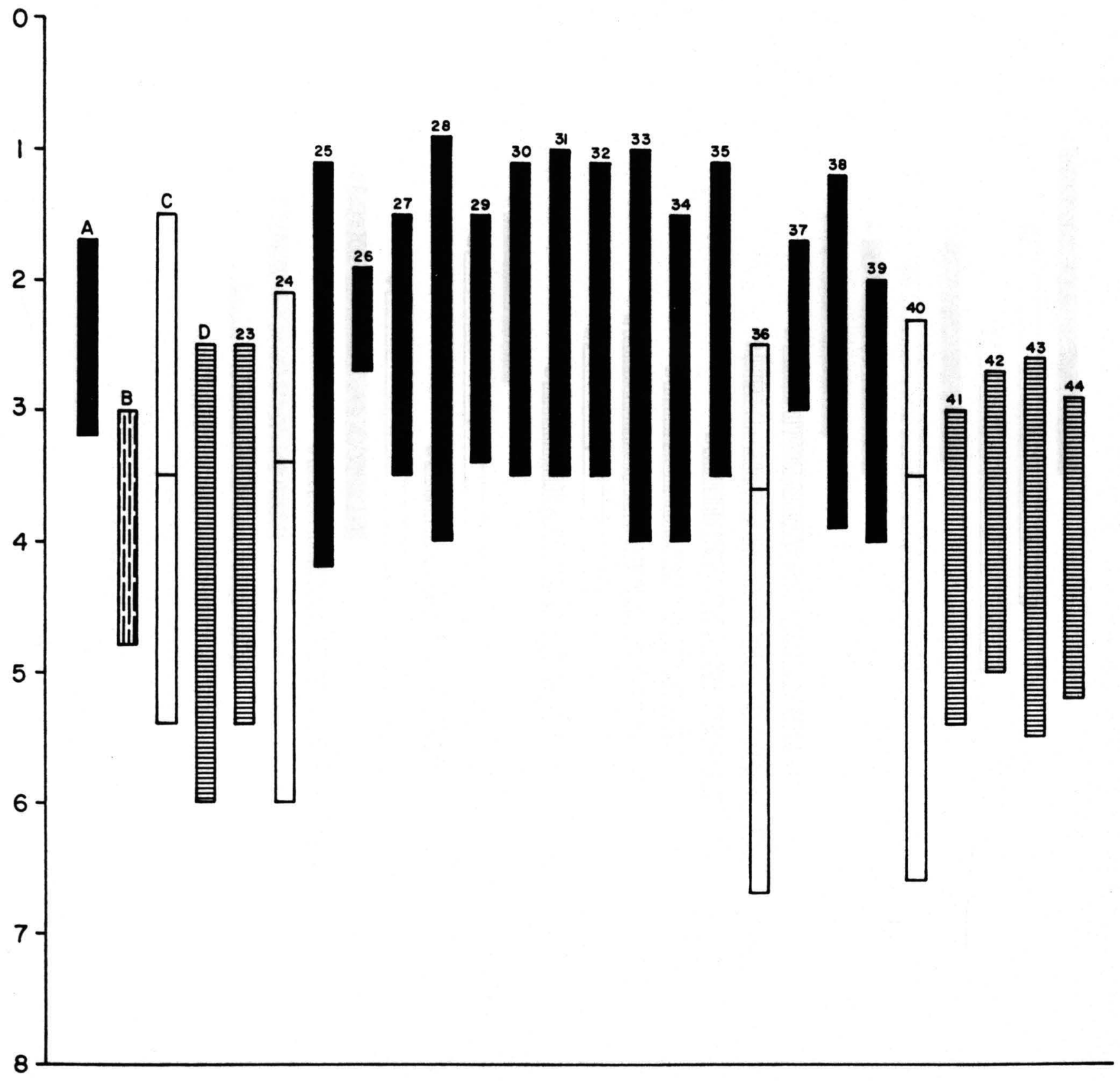

Figura 8. Dendograma da migração eletroforética das bandas de esterase, de acordo com a leitura densitométrica do gel de corrida das cepas de C. perfringens, padrão ATCC 3624, 3626, 3628 e 3629 , respectivamente, tipos $A, B, C$ e $D$ e de 22 de teste isoladas. São Paulo, 1997. 


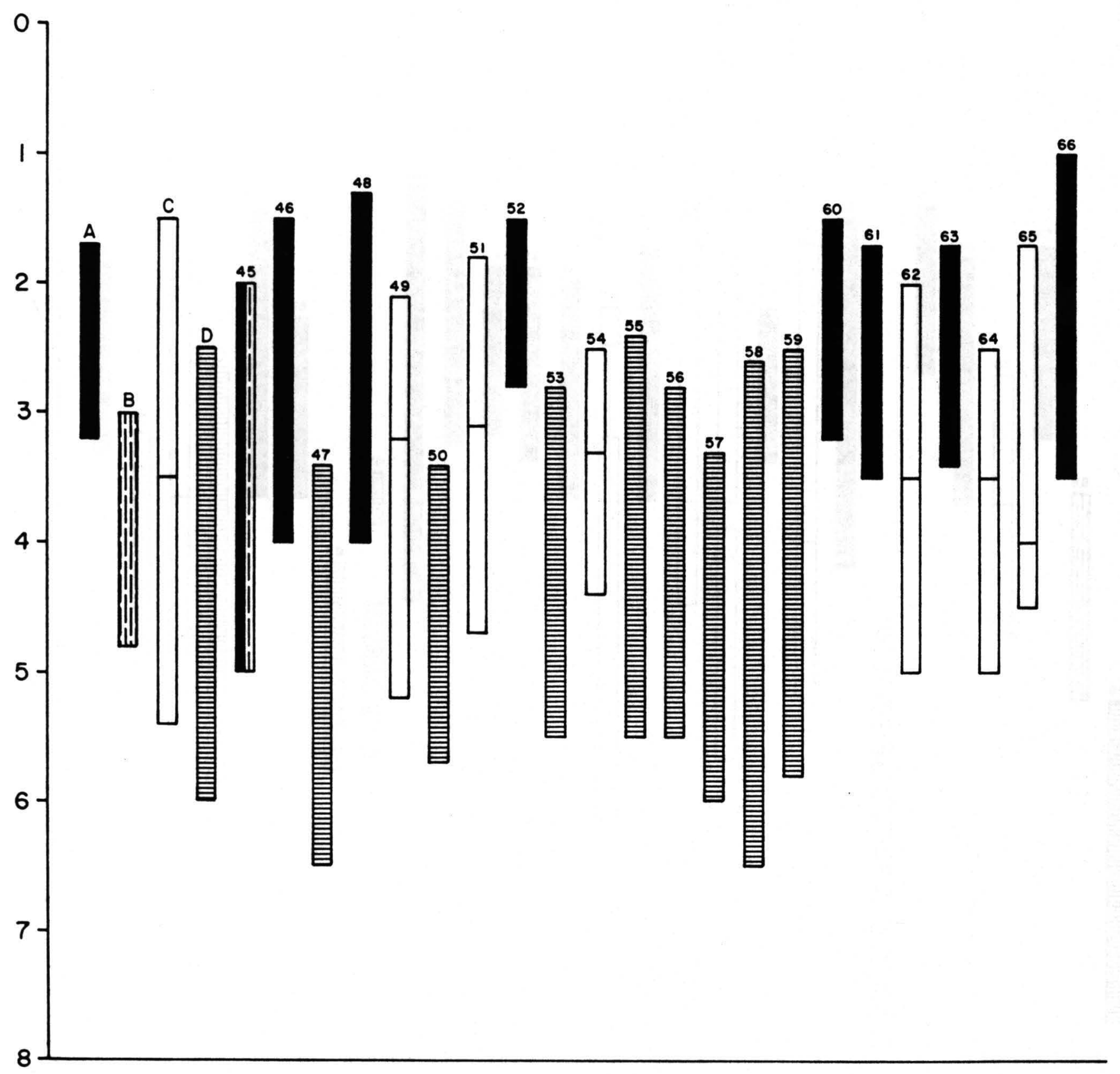

Figura 9. Dendograma da migração eletroforética das bandas de esterase, de acordo com a leitura densitométrica do gel de corrida das cepas de C. perfringens, padrão ATCC $3624,3626,3628$ e 3629 , respectivamente, tipos $A, B, C$ e D e de 22 de teste isoladas. São Paulo. 1997. 


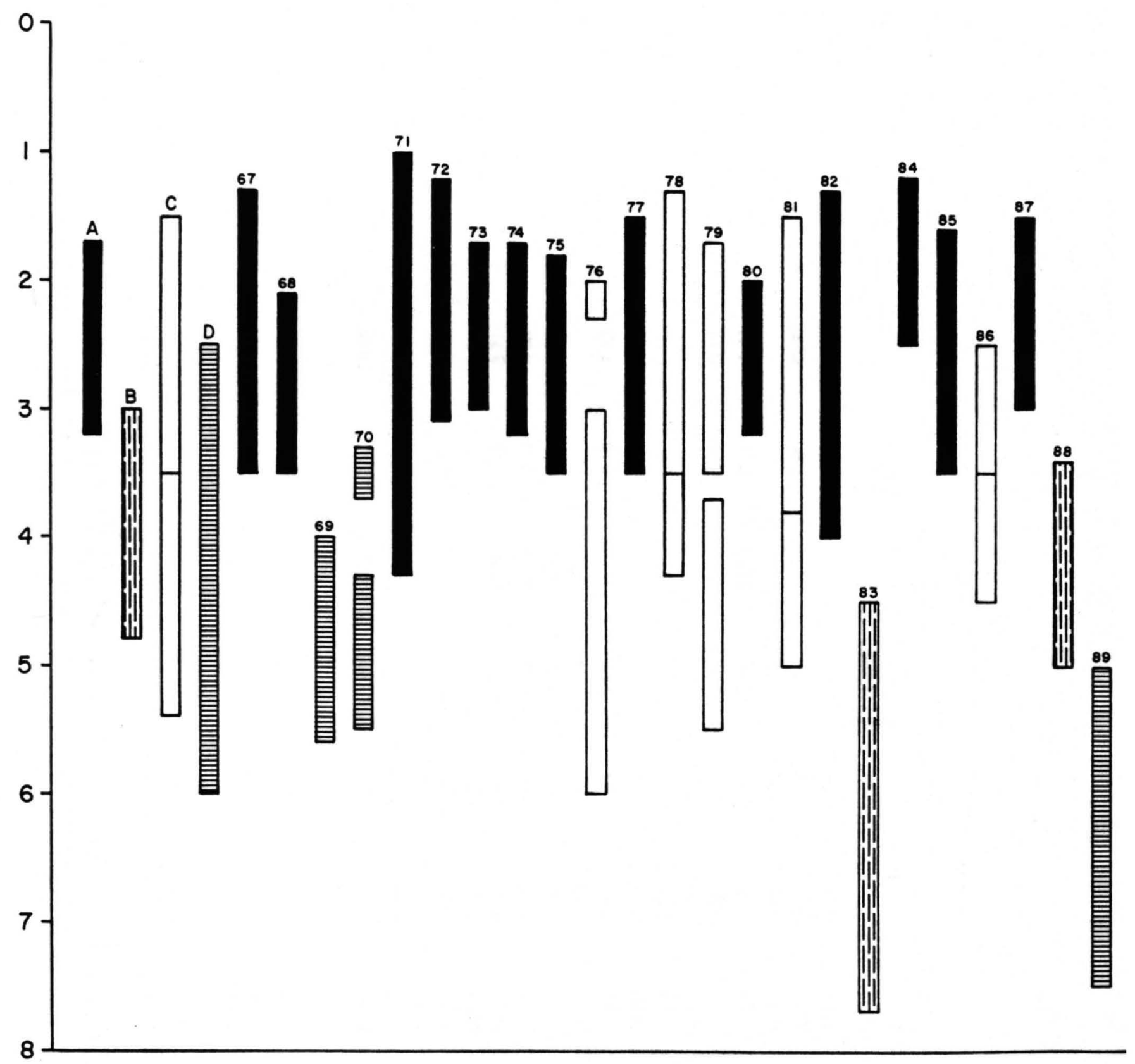

Figura 10. Dendograma da migração eletroforética das bandas de esterase, de acordo com a leitura densitométrica do gel de corrida das cepas de C. perfringens, padrão ATCC $3624,3626,3628$ e 3629 , respectivamente, tipos A, B, C e D e de 23 isoladas. São Paulo, 1997. 
Tabela 2. Valores da porcentagem de volume, área. média de absorbância e relação absorbância x área apresentados pelas bandas de eletroforese corada para esterase, de cepas de $C$ perfringens padrão ATCC 3624 tipo A

3626 tipo B, 3628 tipo C. 3629 tipo D e das 89 de teste isoladas. São Paulo, 1997

\begin{tabular}{|c|c|c|c|c|c|c|c|c|c|c|c|c|}
\hline \multirow{2}{*}{$\begin{array}{c}\text { Amostras } \\
n^{\circ}\end{array}$} & \multicolumn{4}{|c|}{ banda 1} & \multicolumn{4}{|c|}{ banda 2} & \multicolumn{4}{|c|}{ banda3 } \\
\hline & vol. $(\%)$ & área $(\mathrm{mm} 2)$ & m. abs. & absxárea & $\operatorname{vol}(\%)$ & área(mm2) & m. abs. & absxárea & vol. $(\%)$ & área(mm2) & m. abs. & absxárea \\
\hline 1 & 25,69 & 58,52 & 0,34 & 21,14 & & & & & & & & \\
\hline 2 & 26.73 & 45.69 & 0.46 & 21,14 & & & & & & & & \\
\hline 3 & $100, \infty$ & 90,70 & 0,19 & 17,61 & & & & & & & & \\
\hline 4 & 19.20 & 62.96 & 0.42 & 26.58 & & & & & & & & \\
\hline 5 & 31,36 & 79,19 & 0,55 & 43,42 & & & & & & & & \\
\hline 6 & 18.32 & 24.90 & 0.14 & 3.43 & & & & & & & & \\
\hline 7 & 20,85 & 37,12 & 0,15 & 5,50 & & & & & & & & \\
\hline 8 & 19.74 & 40.88 & 0.13 & 5.21 & 59.41 & 90.30 & 0.17 & 15.68 & & & & \\
\hline 9 & 27,57 & 69,18 & 0,55 & 38,16 & & & & & & & & \\
\hline 10 & $100, \infty$ & 77,44 & 0,26 & 20.59 & & & & & & & & \\
\hline 11 & 30,69 & 75,41 & 0,30 & 23,32 & 37,75 & 39,15 & 0,11 & 4,37 & & & & \\
\hline 12 & 14,82 & 48,66 & 0,53 & 25,74 & & & & & & & & \\
\hline 13 & 4,84 & 25,91 & 0,32 & 8.41 & 19.79 & 31.50 & 0,12 & 3,71 & & & & \\
\hline 14 & 3,77 & 24.77 & 0.11 & 2.86 & 5.30 & 30.32 & 0,13 & 4.03 & & & & \\
\hline 15 & 4,42 & 28,11 & 0,12 & 13,11 & 11,53 & 46,14 & 0,19 & 8,76 & & & & \\
\hline 16 & 8.13 & 31.03 & 0.19 & 6.18 & & & & & & & & \\
\hline 17 & 2,50 & 21,09 & 0,09 & 1,90 & 9,63 & 46,14 & 0,16 & 7,32 & & & & \\
\hline 18 & 6.77 & 53,02 & 0.09 & 5.15 & & & & & & & & \\
\hline 19 & 11,09 & 35,83 & 0,54 & 19,26 & & & & & & & & \\
\hline 20 & 11.76 & 59.95 & 0,34 & 20.42 & & & & & & & & \\
\hline 21 & 3,88 & 22,24 & 0,30 & 6.74 & 3,53 & 19.71 & 0,31 & 6,12 & & & & \\
\hline 22 & 6.12 & 34.22 & 0.31 & 10.63 & 37.75 & 39.15 & 0.11 & 4.37 & & & & \\
\hline 23 & 10,67 & 42,97 & 0,43 & 18,53 & & & & & & & & \\
\hline 24 & 6.37 & 25.80 & 0.43 & 11.06 & 18.88 & 54.39 & $0, \infty 0$ & 32.77 & & & & \\
\hline 25 & 8,03 & 40,85 & 0,34 & 13,94 & & & & & & & & \\
\hline
\end{tabular}


continuação da tabela 2

\begin{tabular}{|c|c|c|c|c|c|c|c|c|c|c|c|c|}
\hline \multirow{2}{*}{$\begin{array}{c}\text { Amostras } \\
n^{0}\end{array}$} & \multicolumn{4}{|c|}{ banda 1} & \multicolumn{4}{|c|}{ banda 2} & \multicolumn{4}{|c|}{ banda3 } \\
\hline & vol. $(\%)$ & área $(\mathrm{mm} 2)$ & m. abs. & absxárea & $\operatorname{vol}(\%)$ & área $(\mathrm{mm} 2)$ & m. abs. & absxárea & vol. $(\%)$ & área(mm2) & m. abs. & absxárea \\
\hline 26 & 13,66 & 39,35 & 0,17 & 6,74 & & & & & & & & \\
\hline 27 & 25.70 & 48.52 & 0.26 & 12.69 & & & & & & & & \\
\hline 28 & 60,65 & 68,13 & 0,44 & 29,95 & & & & & & & & \\
\hline 29 & 100,00 & 47.47 & 0.47 & 22.58 & & & & & & & & \\
\hline 30 & 47,35 & 33,81 & 0,28 & 9,60 & & & & & & & & \\
\hline 31 & 24,34 & $41, \infty 3$ & 0.24 & 10.08 & & & & & & & & \\
\hline 32 & 6,57 & 42,19 & 0,27 & 11,65 & & & & & & & & \\
\hline 33 & 100.00 & 59.28 & 0.24 & 14.61 & & & & & & & & \\
\hline 34 & 52,65 & 40,72 & 0,26 & 10,67 & & & & & & & & \\
\hline 35 & 47.58 & 70.73 & 0.53 & 37,63 & & & & & & & & \\
\hline 36 & 6,35 & 29.70 & 0.17 & 5,02 & 9.25 & 35,35 & 0,20 & 7,31 & & & & \\
\hline 37 & 7.08 & 43.19 & 0.29 & 12.54 & & & & & & & & \\
\hline 38 & 28,12 & 50,36 & 0,23 & 11,64 & & & & & & & & \\
\hline 39 & 5,20 & 30.88 & 0.13 & 4.11 & & & & & & & & \\
\hline 40 & 2,53 & 22,64 & 0,15 & 4,36 & 5,52 & 28,79 & 0,15 & 4,36 & & & & \\
\hline 41 & 8.66 & 43.78 & 0.16 & 6.84 & & & & & & & & \\
\hline 42 & 9,08 & 42,55 & 0,17 & 7,18 & & & & & & & & \\
\hline 43 & 10,83 & 40,05 & 0.21 & 8.56 & & & & & & & & \\
\hline 44 & 4,04 & 26,23 & 0,12 & 3,19 & & & & & & & & \\
\hline 45 & 16.49 & 45,5 & 0.28 & 13.04 & 19.70 & 31,50 & 0.12 & 3.70 & & & & \\
\hline 46 & 13,97 & 50,31 & 0,22 & 11,05 & & & & & & & & \\
\hline 47 & 8.07 & 47,34 & 0,13 & 6.38 & & & & & & & & \\
\hline 48 & 62,44 & 57,38 & 0,14 & 8,01 & & & & & & & & \\
\hline 49 & 37.56 & 44.36 & 0,11 & 4,82 & 7.49 & 35.41 & 0,37 & 13.28 & & & & \\
\hline 50 & 33,87 & 34,26 & 0.28 & 9,74 & & & & & & & & \\
\hline
\end{tabular}


continuação da tabela 2

\begin{tabular}{|c|c|c|c|c|c|c|c|c|}
\hline \multirow{2}{*}{$\begin{array}{c}\text { Amostra } \\
n^{\circ}\end{array}$} & \multicolumn{4}{|c|}{ banda 1} & \multicolumn{4}{|c|}{ banda 2} \\
\hline & vol. $(\%)$ & área $(\mathrm{mm} 2)$ & m. abs. & absxárea & vol. $(\%)$ & área $(\mathrm{mm} 2)$ & m. abs. & absxárea \\
\hline 51 & 5,91 & 26.88 & 0.40 & 10.48 & 7.09 & 35.42 & 0,35 & 12.56 \\
\hline 52 & 5,04 & 37,48 & 0,24 & 8,94 & & & & \\
\hline 53 & 20,83 & 31.62 & 0,19 & 5.99 & & & & \\
\hline 54 & 3,33 & 27,62 & 0,21 & 5,90 & 2,71 & 18,85 & 0,25 & 4,80 \\
\hline 55 & 13.50 & 43,52 & 0.36 & 15,62 & & & & \\
\hline 56 & 9,98 & 34,5 & 0,33 & 11,56 & & & & \\
\hline 57 & 9,31 & 42,18 & 0,25 & 10,77 & & & & \\
\hline 58 & 15,64 & 54,02 & 0,33 & 18,11 & & & & \\
\hline 59 & 14,64 & 57,74 & 0.29 & 16,95 & & & & \\
\hline 60 & 27,33 & 36,31 & 0,14 & 5,12 & & & & \\
\hline 61 & $100, \infty$ & 62.48 & 0.11 & 6.72 & & & & \\
\hline 62 & 14,22 & 31,12 & 5,89 & 0.19 & 33,32 & 50,63 & 0,27 & 13,8 \\
\hline $\mathfrak{3}$ & 19.87 & 33.47 & 0.13 & 4,46 & & & & \\
\hline 64 & 18,89 & 42,58 & 0,10 & 4,24 & 3,53 & 19.71 & 0,31 & 6,12 \\
\hline$\infty$ & 23.34 & 45.02 & 0.11 & 5,24 & 17.63 & 31,73 & 0.12 & 3,96 \\
\hline 66 & 20,26 & 34,23 & 0,13 & 4,55 & & & & \\
\hline 67 & 62.25 & 32.51 & 0.22 & 7,21 & & & & \\
\hline 68 & $100, \infty$ & 63,82 & 0,19 & 12,57 & & & & \\
\hline 69 & 8,00 & 20.76 & 0.11 & 2.30 & & & & \\
\hline 70 & 7,36 & 20,66 & 0,10 & 2,12 & & & & \\
\hline 71 & 14.72 & $26, \infty 0$ & 0,16 & 4.23 & & & & \\
\hline 72 & 25,60 & 51,37 & 0,18 & 9,36 & & & & \\
\hline 73 & 8,10 & 45.52 & 0,31 & 14,36 & & & & \\
\hline 74 & 32,78 & 49,71 & 0,67 & 33,23 & & & & \\
\hline 75 & 17.95 & 24.20 & 0.14 & 3,36 & & & & \\
\hline
\end{tabular}


continuação da tabela 2

\begin{tabular}{|c|c|c|c|c|c|c|c|c|c|c|c|c|}
\hline \multirow{2}{*}{$\begin{array}{c}\text { Amostra } \\
n^{\circ}\end{array}$} & \multicolumn{4}{|c|}{ banda 1} & \multicolumn{4}{|c|}{ banda 2} & \multicolumn{4}{|c|}{ banda3 } \\
\hline & vol. $(\%)$ & área(mm2) & m. abs. & absxárea & vol. $(\%)$ & área(mm2) & m. abs. & absxárea & vol. $(\%)$ & área $(\mathrm{mm} 2)$ & m. abs. & absxárea \\
\hline 76 & 15.21 & 26.70 & 0.16 & 4,37 & 19.79 & 31.52 & 0.12 & 3.71 & & & & \\
\hline 77 & 23,92 & 45,54 & 0,53 & 24,24 & & & & & & & & \\
\hline 78 & 62,08 & 66.40 & 0.34 & 22.73 & 12,33 & 32,66 & 0.14 & 4.51 & & & & \\
\hline 79 & 4,61 & 23,10 & 0,23 & 5,34 & 4,58 & 23,1 & 0,23 & 5,31 & & & & \\
\hline 80 & 16.61 & 24.20 & 0.14 & 3.36 & & & & & & & & \\
\hline 81 & 15,22 & 59,40 & 0,45 & 26,99 & 6.29 & 37,16 & 0,30 & 11,15 & & & & \\
\hline 82 & 6,22 & 29.77 & 0,24 & 7,20 & & & & & & & & \\
\hline 83 & 8,36 & 32,63 & 0,29 & 9,68 & & & & & & & & \\
\hline 84 & 43,30 & 55.96 & 0,78 & 43.89 & & & & & & & & \\
\hline 85 & 11,44 & 47,35 & 0,43 & 20,28 & & & & & & & & \\
\hline 86 & 5,89 & 32.07 & 0,32 & 10.44 & 7.84 & 40.16 & 0,34 & 13,90 & & & & \\
\hline 87 & 21,87 & 73,69 & 0,41 & 30,27 & & & & & & & & \\
\hline 88 & 58,40 & 40,42 & 0,27 & 11.25 & & & & & & & & \\
\hline 89 & 41,60 & 44,61 & 0,18 & 8,02 & & & & & & & & \\
\hline \multicolumn{13}{|l|}{ Padroes } \\
\hline A & 44,29 & 50,61 & 0,53 & 26,82 & & & & & & & & \\
\hline B & 41.97 & 13.12 & $0, \infty$ & 1,30 & & & & & & & & \\
\hline$c$ & 22,49 & 45,25 & 0,30 & 13,62 & 8,10 & 27,43 & 0,17 & 4,90 & & & & \\
\hline$D$ & 21.73 & 49.44 & 0.26 & 13.16 & & & & & & & & \\
\hline
\end{tabular}




\subsection{Teste sorológico}

Os anti-soros $\left(A_{s}\right)$, preparados com as células bacterianas de $C$. perfringens padrão (ATCC) tipos $A, B, C$ e $D$, obtidos em coelhos (item 3.2.5.1), foram analisados por teste de imunodifusão, frente a antígenos $\left(A_{g}\right)$ constituídos por extratos das cepas de teste isoladas, originadas de culturas com concentrações aproximadas de $10^{4}$ bactérias $/ \mathrm{mL}$ e não mostraram nenhuma linha de precipitação.

Com os mesmos $A_{s}$ foi realizado o teste de ELISA indireto, empregando-se como $A_{g}$ as células bacterianas das cepas padrão. Os ensaios de padronização das melhores concentraçōes a serem utilizadas indicaram o emprego dos $A_{g}$ na concentração de $600 \mu \mathrm{g}$ em equivalentes de $\mathrm{SAB} / \mathrm{mL}$ e do conjugado anti-lgG, marcado com a enzima fosfatase, na diluição de 1:5. Os $A_{s}$ foram utilizados sem diluição, uma vez que não apresentaram reação na imunodifusão.

A Tabela 3 mostra, no teste de ELISA, os valores das leituras de absorbância, empregando-se filtro de $405 \mathrm{~nm}$, para cada um dos tipos de $A_{s}$, preparados em coelhos contra as cepas padrão ATCC e seus extratos. As medidas de absorbância encontradas demonstram sensibilidade para os quatro $A_{g}$, porém com baixa especificidade. Os $A_{s}$ contra os tipos $C$ e $B$ revelam o maior grau de sensibilidade para $\circ A_{g} D$. Para $\circ A_{s}$ contra o tipo $A$ a maior absorbância é observada em relação ao próprio $A_{g}$, seguido pelo $D$. $O A_{s}$ do tipo $D$ reconhece o seu próprio $A_{g}$, apresentando, no entanto, reação cruzada com o do $A$, seguido pelos dos tipos $B$ e C. Não foi observada nenhuma reação com o soro normal e tampouco com os reagentes empregados, em relação aos quatro $A_{s}$ utilizados. 
Tabela 3. Valores das absorbâncias obtidas no teste de ELISA para cepas de $C$. perfringens padrão ATCC 3624 tipo A, 3626 tipo B, 3638 tipo C e 3629 tipo $D$, frente a anti-soros contra estas mesmas cepas, obtidos em coelhos. São Paulo, 1997.

\begin{tabular}{ccccc}
\hline antigenos & \multicolumn{4}{c}{ anti-soros $\left(\mathbf{A}_{\mathbf{s}}\right)$} \\
\cline { 2 - 5 }$\left(\mathrm{A}_{\mathrm{o}}\right)$ & $\mathrm{A}$ & $\mathrm{B}$ & $\mathrm{C}$ & $\mathrm{D}$ \\
\hline A & 222 & 299 & 299 & 504 \\
B & 153 & 280 & 322 & 452 \\
C & 144 & 255 & 344 & 433 \\
D & 191 & 319 & 360 & 507 \\
\hline
\end{tabular}

Na Tabela 4 estão relacionados os valores da absorbância, empregandose filtro de $405 \mathrm{~nm}$, obtidos na leitura da reação entre os extratos de cada uma das cepas de teste isoladas empregadas como $A_{g}$ e cada um dos $A_{s}$ obtidos, assim como a caracterização dos tipos de $C$. perfringens. Observando-se a classificação nos vários tipos, de acordo com as leituras depreende-se que de todas as cepas, somente $1(1,1 \%)$ foi classificada como do tipo C, $36(40,4 \%)$ do tipo A, $30(33,7 \%)$ do D e $9(10,1 \%)$ de B. Pelo ensaio imunoenzimático ocorreu indefinição entre os tipos em $13(14,6 \%)$ cepas. 
Tabela 4. Valores das absorbâncias obtidas no teste de ELISA para cepas de $\mathrm{Cl}$. perfringens frente a anti-soros padrão, tipos A, B, C e D. São Paulo, 1997.

\begin{tabular}{|c|c|c|c|c|c|c|c|c|c|c|c|}
\hline \multirow[t]{2}{*}{ antígenos } & \multicolumn{4}{|c|}{ anti-soros } & \multirow{2}{*}{$\begin{array}{l}\text { c.p. } \\
\text { tipo }\end{array}$} & \multirow[t]{2}{*}{ antigenos } & \multicolumn{3}{|c|}{ anti-soros } & \multirow[b]{2}{*}{ D } & \multirow{2}{*}{$\begin{array}{l}\text { C.p. } \\
\text { tipo }\end{array}$} \\
\hline & A & $B$ & $\mathrm{C}$ & D & & & $A$ & $B$ & C & & \\
\hline 1 & 264 & 389 & 319 & 415 & D & 46 & 591 & 1.097 & 362 & 824 & B \\
\hline 2 & 197 & 915 & 342 & 880 & B & 47 & 246 & 349 & 368 & 428 & D \\
\hline 3 & 1.738 & 976 & 320 & 933 & A & 48 & 169 & 327 & 370 & 470 & $D$ \\
\hline 4 & 1.410 & 926 & 341 & 841 & $A$ & 49 & 165 & 313 & 370 & 446 & $D$ \\
\hline 5 & 925 & 865 & 332 & 773 & A & 50 & 238 & 342 & $3 \pi$ & 454 & $D$ \\
\hline 6 & 1.222 & 946 & 334 & 774 & A & 51 & 263 & 390 & 374 & 475 & D \\
\hline 7 & 1.215 & 974 & 350 & 876 & A & 52 & 232 & 368 & 309 & 511 & $D$ \\
\hline 8 & 971 & 776 & 285 & 812 & A & 53 & 364 & 412 & 325 & 493 & $D$ \\
\hline 9 & 1.156 & 957 & 321 & 819 & A & 54 & 152 & 300 & 321 & 332 & $C / D$ \\
\hline 10 & 1.131 & 943 & 312 & 994 & A & 55 & 242 & 349 & 326 & 477 & D \\
\hline 11 & 971 & 1.058 & 303 & 889 & B & 56 & 243 & 369 & 327 & 439 & $D$ \\
\hline 12 & 1.067 & 1.061 & 311 & 977 & $A / B$ & 57 & 169 & 348 & 321 & 488 & D \\
\hline 13 & 1.223 & 810 & 291 & 814 & $A$ & 58 & 213 & 304 & 338 & 450 & D \\
\hline 14 & 834 & 845 & 314 & 972 & D & 59 & 334 & 384 & 310 & 477 & D \\
\hline 15 & 1.053 & 1.105 & 378 & 1005 & B & 60 & 232 & 377 & 340 & 451 & $D$ \\
\hline 16 & $\$ 97$ & 765 & 386 & 982 & $A / D$ & 61 & 206 & 450 & 376 & 378 & B \\
\hline 17 & 345 & 467 & 354 & 495 & $B / D$ & 62 & 178 & 279 & 386 & 292 & C \\
\hline 18 & 904 & 650 & 315 & 658 & $A$ & 63 & 273 & 414 & 373 & 456 & $D$ \\
\hline 19 & 1047 & 1.024 & 380 & 879 & $A / B$ & 64 & 167 & 407 & 376 & 518 & D \\
\hline 20 & 722 & 873 & 372 & 771 & B & $\infty$ & 131 & 463 & 381 & 435 & $B / D$ \\
\hline 21 & 1.054 & 915 & 365 & 1.044 & $A / D$ & 66 & 934 & 893 & 414 & 699 & $A$ \\
\hline 22 & 1000 & 951 & 357 & 777 & $A$ & 67 & 244 & $4 \pi 7$ & 366 & 508 & $D$ \\
\hline 23 & 1.174 & 967 & 360 & 550 & A & 68 & 259 & 352 & 350 & 386 & $D$ \\
\hline 24 & 1126 & 971 & 371 & 649 & A & 69 & 227 & 348 & 348 & 438 & D \\
\hline 25 & 1.232 & 1.0055 & 375 & 1.049 & A & 70 & 187 & 258 & 361 & 529 & D \\
\hline 26 & 1.335 & 946 & 374 & 1.053 & A & 71 & 232 & 351 & 384 & 419 & $C / D$ \\
\hline 27 & 716 & 716 & 363 & 1.025 & $D$ & 72 & 170 & 340 & 362 & 452 & $\mathrm{D}$ \\
\hline 28 & 824 & 383 & 367 & 781 & A & 73 & 187 & 384 & 381 & 500 & $D$ \\
\hline 29 & 948 & 749 & 348 & 877 & $A$ & 74 & 684 & 687 & 356 & 740 & D \\
\hline 30 & 193 & 519 & 361 & 541 & $B / D$ & 75 & 165 & 416 & 372 & 479 & D \\
\hline 31 & 173 & 990 & 345 & 989 & $B / D$ & 76 & 426 & 405 & 279 & 245 & $A / B$ \\
\hline 32 & 1.434 & 1.075 & 359 & 1.102 & A & 77 & 452 & 327 & 312 & 284 & A \\
\hline 33 & 496 & 604 & 386 & 857 & D & 78 & 224 & 297 & 307 & 458 & D \\
\hline 34 & 323 & 387 & 337 & 456 & $D$ & 79 & 239 & 394 & 290 & 446 & D \\
\hline 36 & 319 & 387 & 397 & 418 & $C / D$ & 80 & 968 & 924 & 315 & 914 & A \\
\hline 36 & 902 & 807 & 368 & 730 & A & 81 & 1.044 & 979 & 342 & 565 & A \\
\hline 37 & 846 & 600 & 393 & 513 & A & 82 & 1.075 & 947 & 309 & 876 & $A$ \\
\hline 38 & 576 & 654 & 353 & 399 & B & 83 & 953 & 995 & 301 & 750 & B \\
\hline 30 & 716 & 567 & 374 & 626 & A & 84 & 1.205 & 863 & 318 & 879 & $A$ \\
\hline 40 & 885 & 491 & 394 & 563 & A & 85 & 1.217 & 1.019 & 221 & 800 & A \\
\hline 41 & 715 & 594 & 379 & 541 & A & 86 & 1.244 & 851 & 320 & 997 & A \\
\hline 42 & 586 & 678 & 375 & 430 & B & 87 & 1.224 & 914 & 294 & 747 & A \\
\hline 43 & 852 & 784 & 378 & 660 & A & 88 & 1.098 & 958 & 314 & 898 & A \\
\hline 44 & 1.098 & 760 & 355 & 682 & A & 89 & 1.024 & 973 & 337 & 1.036 & $A / D$ \\
\hline 45 & 929 & 686 & 362 & 882 & A & & & & & & \\
\hline
\end{tabular}




\subsection{Exaltação da virulência}

A partir dos resultados distribuídos no Quadro 5, obtidos nos testes de toxigenicidade das cepas de teste isoladas, foram selecionadas 10 que apresentaram variação no teste ou sejam: toxigênicas em sua forma sem tratamento e após o tratamento por tripsina (10 e 19), atoxigênicas somente sem tratamento (26 e 68), toxigênicas apenas após o tratamento (11 e 88) e que não revelaram toxigenicidade em ambas as formas (12, 20, 23 e 27).

Nas inoculações de cobaias com estas cepas, verificou-se que para as já toxigênicas uma ou duas passagens eram suficientes para terem sua virulência exaltada, enquanto as atoxigênicas só passavam a manifestar patogenicidade, com cinco, ou até, seis passagens.

Os géis da eletroforese e os densitogramas correspondentes a essas cepas, em sua forma original e após a exaltação da virulência, são apresentados nas Figuras de números 11 a 24. As medidas da porcentagem do volume das bandas, sua área, média da absorbância e relação absorbância $x$ área, sāo apresentadas na Tabela 5.

Em eletroforese, as cepas padrão dos tipos A (Figura 11) e D (Figura 14) apresentaram bandas comuns em ambas as formas original e com virulência exaltada, a do tipo B exaltada (Figura 13) passou a exibir 3 bandas, a do tipo $C$, em sua forma original demonstrou 2 bandas, e na exaltada apenas uma.

Para as cepas de teste isoladas, na forma exaltada, verifica-se no perfil eletroforético corado para esterase, que para 8 delas não houve alteração. Porém, as cepas $20_{e}$ e $68_{\theta}$ passaram a apresentar, respectivamente, 2 e 3 bandas, quando apenas uma era observada, anteriormente. A confirmação da existência destas novas bandas é mostrada na Tabela 5 , que registra os valores relativos a atividade das mesmas (absorbância $x$ área). 

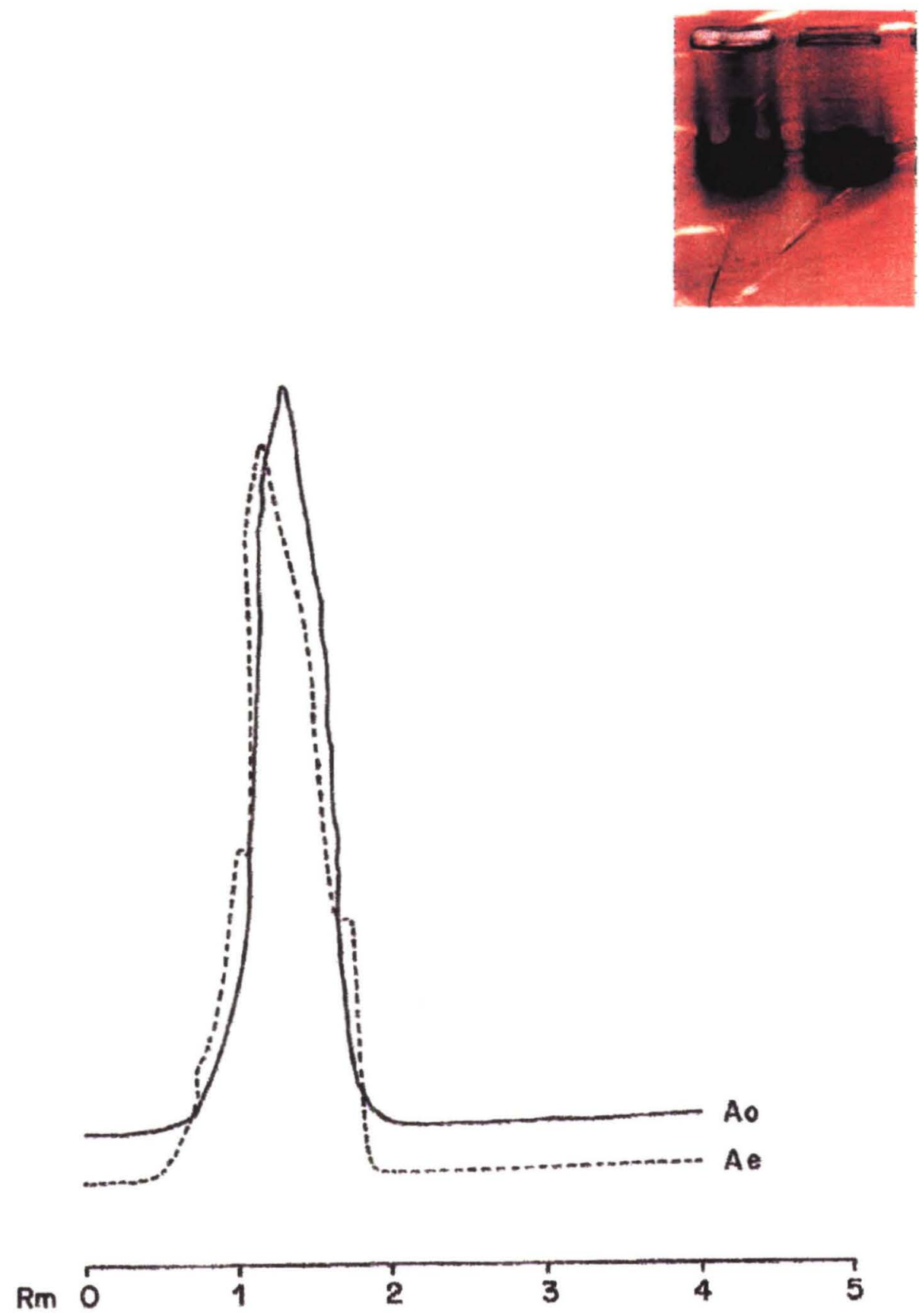

Figura 11. Densitometria e gráfico da migração eletroforética do gel de poliacrilamida corado para esterase, da cepa padrão ATCC 3624 de $C$. perfringens do tipo $A$, na sua forma original $\left(A_{0}\right)$ e exaltada (Ae). São Paulo, 1997. 

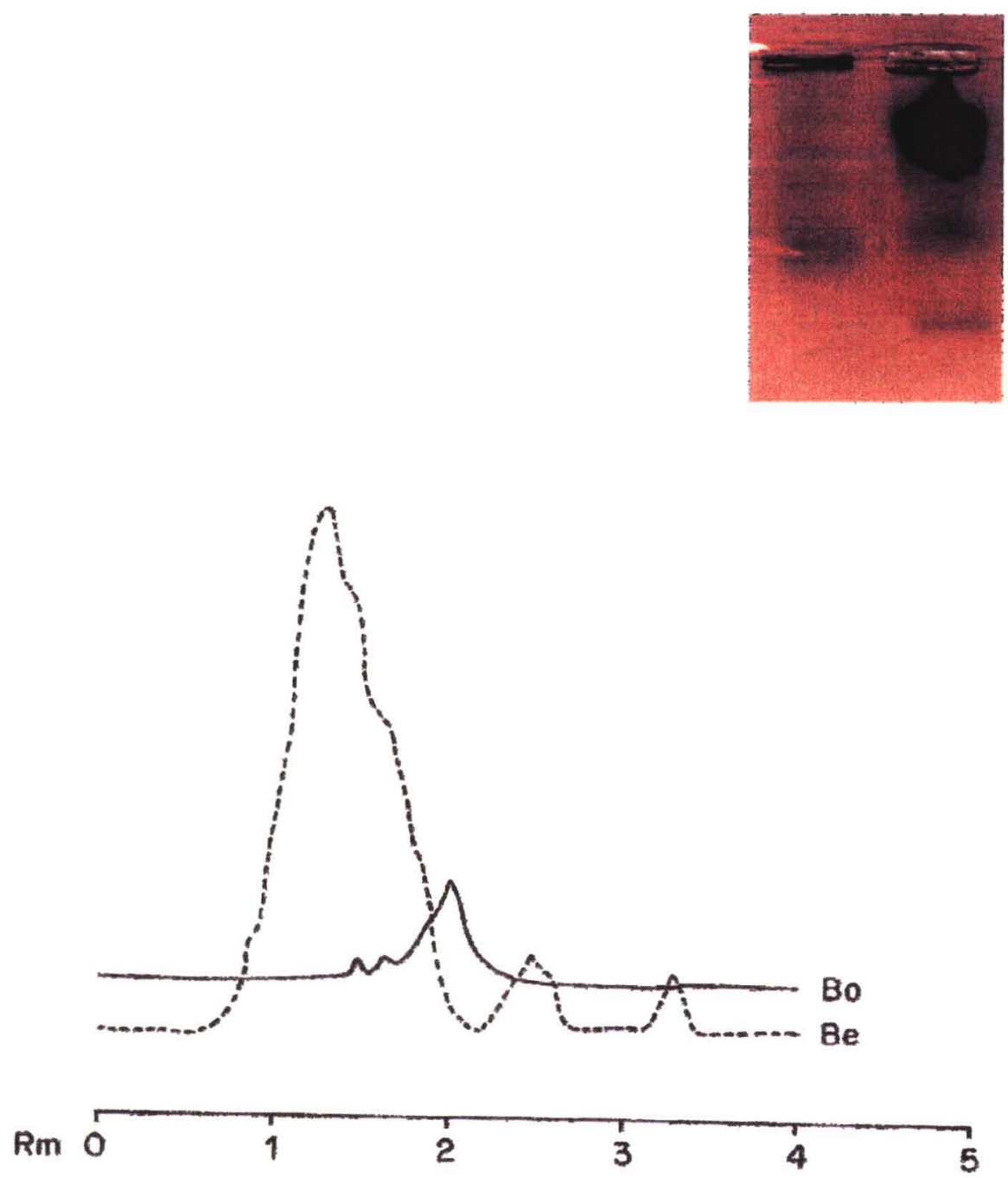

Figura 12. Densitometria e gráfico da migraçäo eletroforética do gel de poliacrilamida, corado para esterase, da cepa padrão ATCC 3626 de $C$. perfringens do tipo $B$, na sua forma original $\left(B_{0}\right)$ e com virulência exaltada (Be). São Paulo, 1997. 


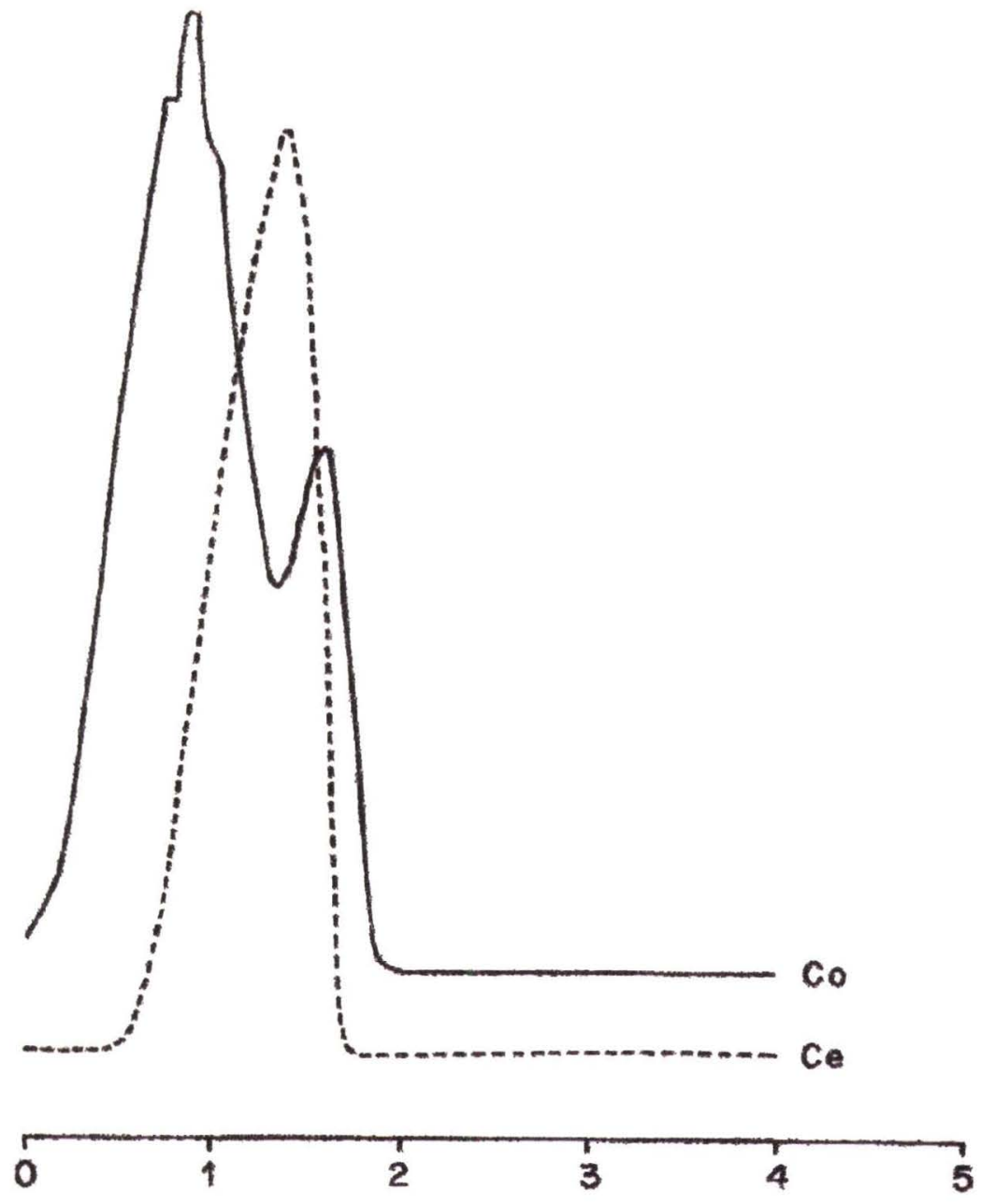

Figura 13. Densitometria e gráfico da migração eletroforética do gel de poliacrilamida, corado para esterase, da cepa padrão ATCC 3628 de $C$. perfingens do tipo $C$, na sua forma original $\left(C_{0}\right)$ e com virulência exaltada $\left(C_{e}\right)$. São Paulo, 1997. 

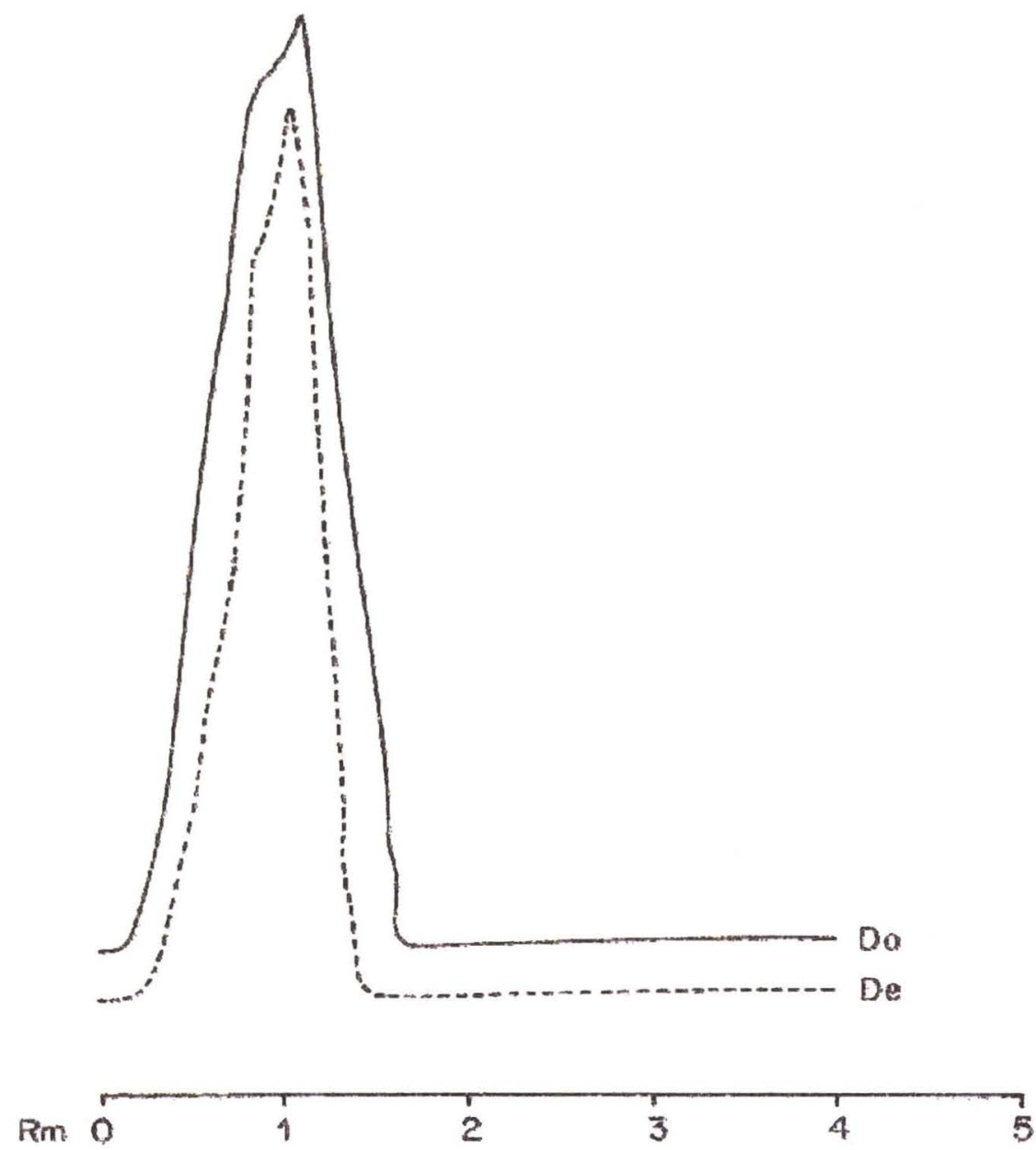

Figura 14. Densitometria e gráfico da migração eletroforética do gel de poliacrilamida, corado para esterase, da cepa padräo ATCC 3629 de C. perfringens do tipo $D$, na sua forma original $\left(D_{0}\right)$ e exaltada (De), São Paulo, 1997. 


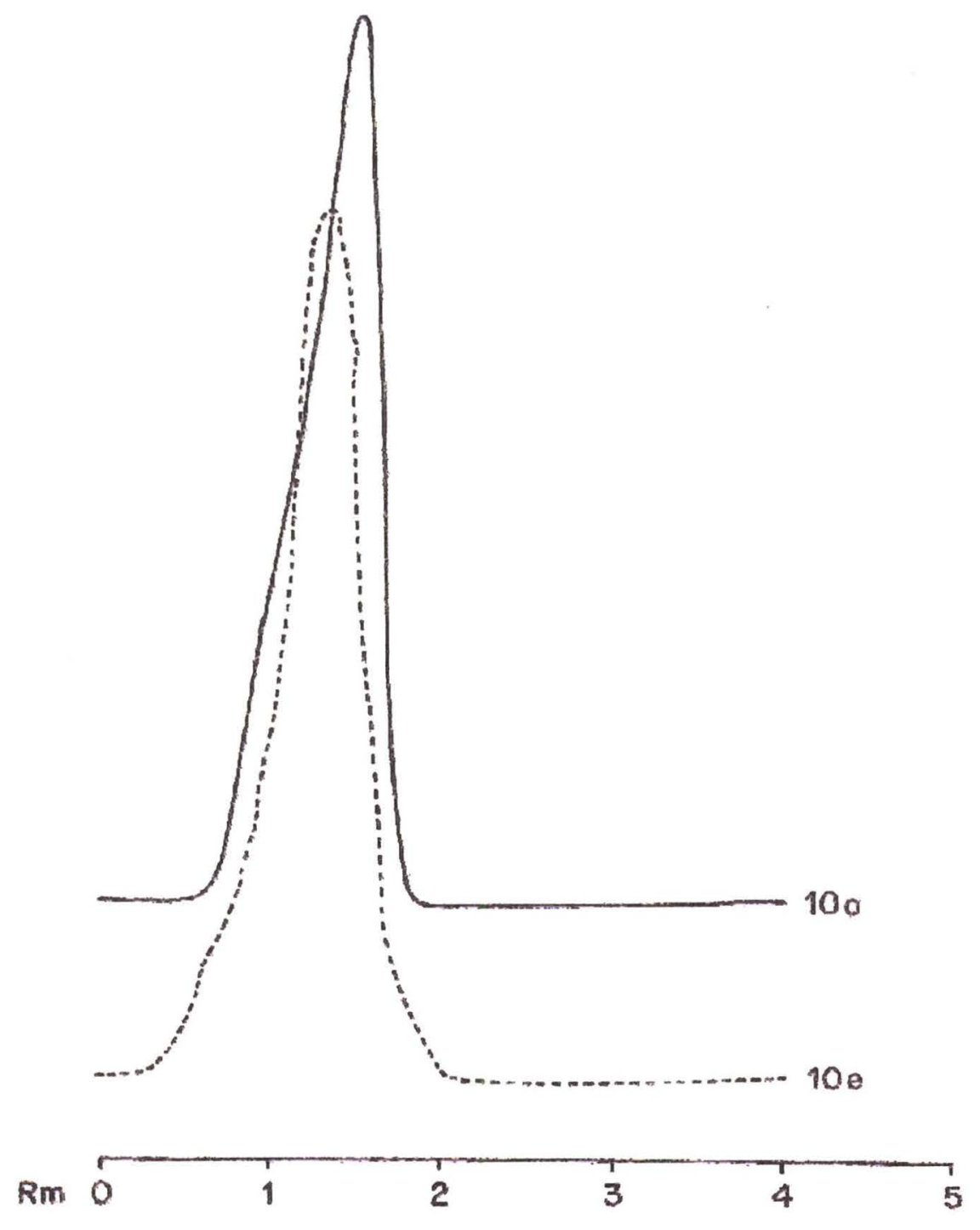

Figura 15. Densitometria e gráfico da migração eletroforética do gel de poliacrilamida, corado para esterase, da cepa $n^{\circ} 10 \mathrm{C}$. perfringens de teste isolada, na sua forma original $\left(10_{0}\right)$ e exaltada $\left(10_{e}\right)$. São Paulo, 1997. 

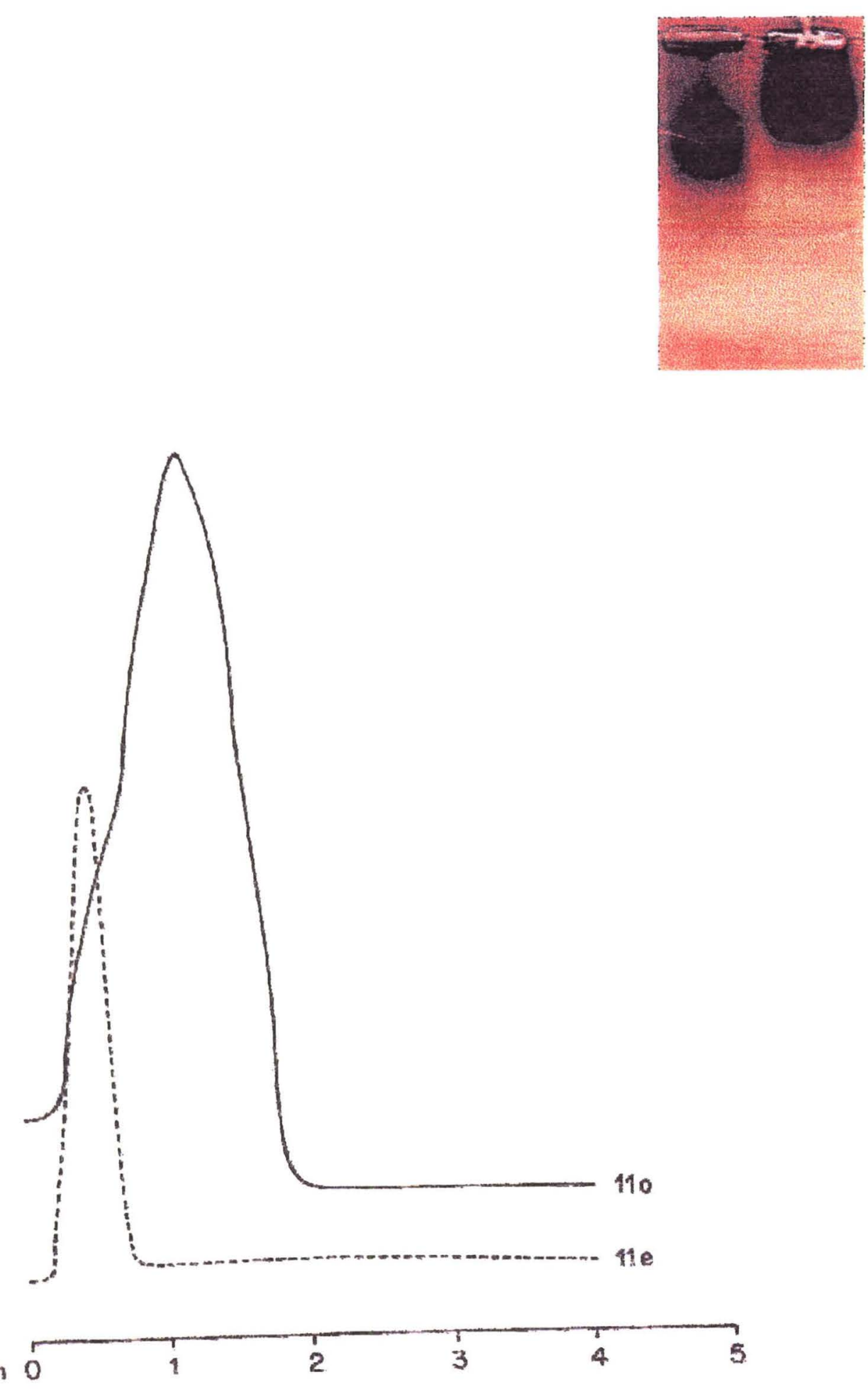

Figura 16. Densitometria e gráfico da migração eletroforética do gel de poliacrilamida, corado para esterase, da cepa $\mathrm{n}^{\circ} 11$ de $C$. perfringens de teste isolada, na sua forma original (110) e exaltada (11)), São Paulo, 1997. 

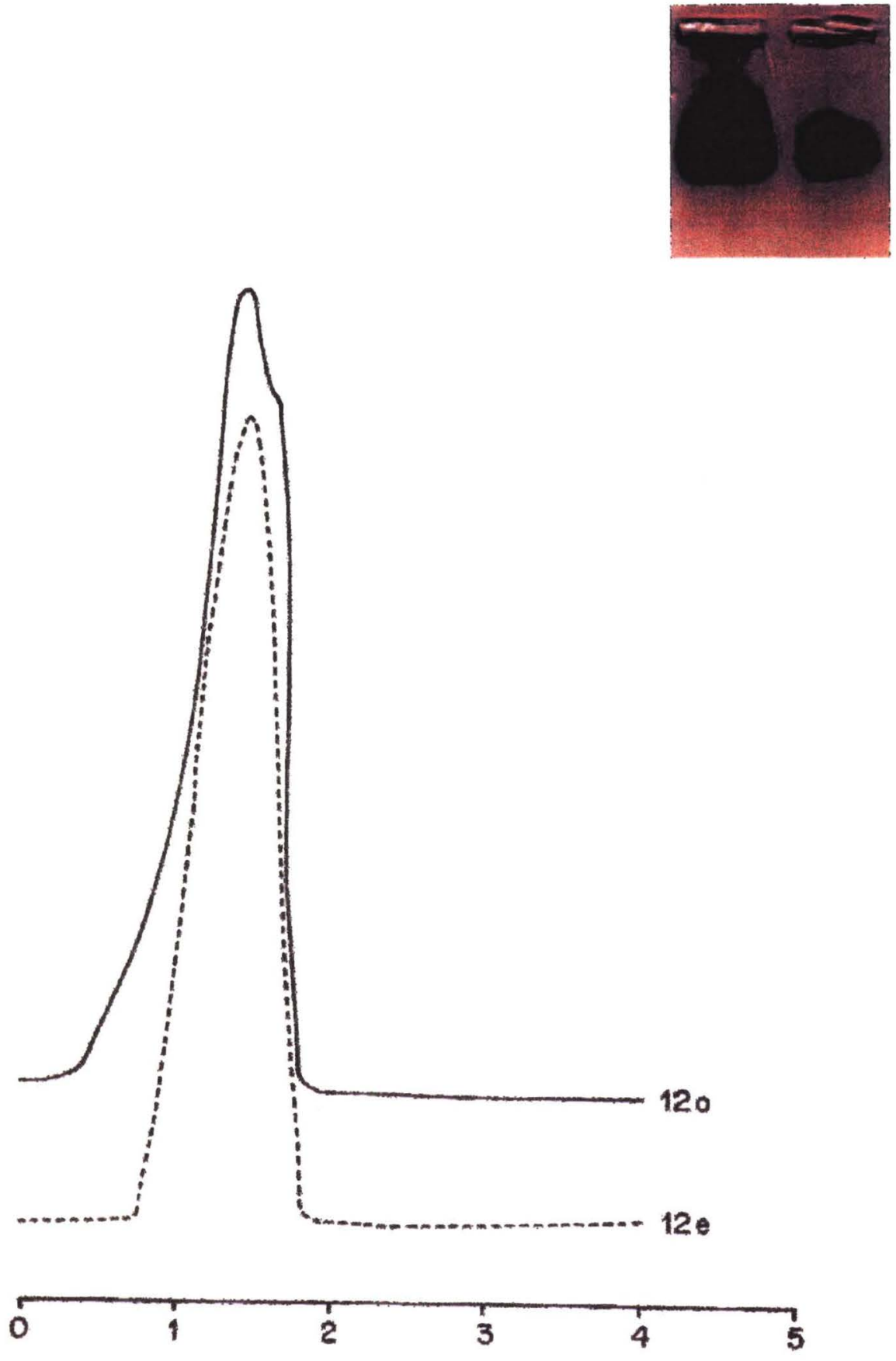

Figura 17. Densitometria e gráficao da migração eletroforética do gel de poliacrilamida, corado para esterase, da cepa $n^{\circ} 12$ de $C$. perfringens de teste isolada, na sua forma original $\left(12_{0}\right)$ e exaltada (12e). São Paulo, 1997. 


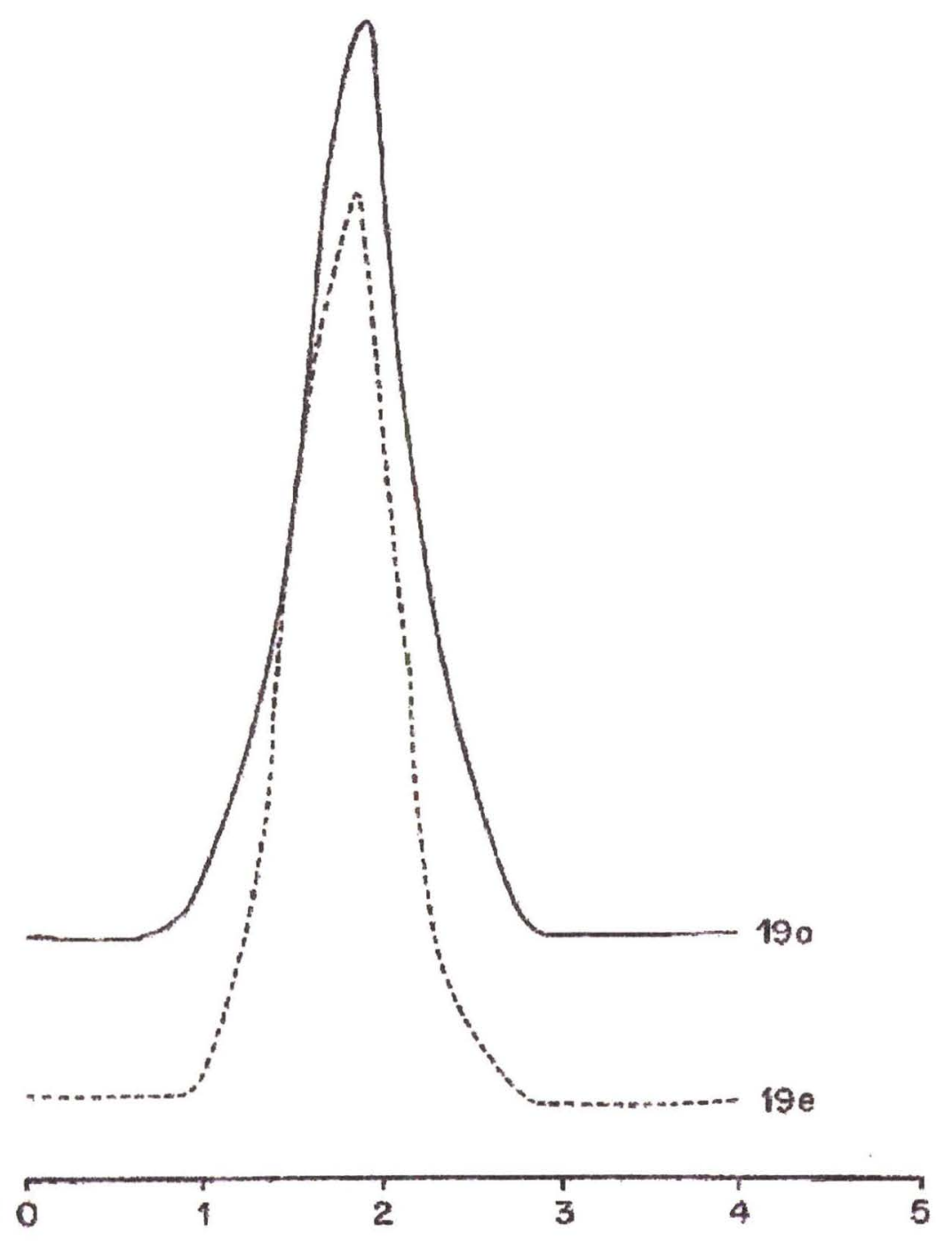

Figura 18. Densitometria e gráfico da migração eletroforética do gel de poliacrilamida, corado para esterase, da cepa $\mathrm{n}^{0} 19$ de $C$. perfringens de teste isolada, na sua forma original $\left(19_{0}\right)$ e exaltada (19)), São Paulo, 1997. 

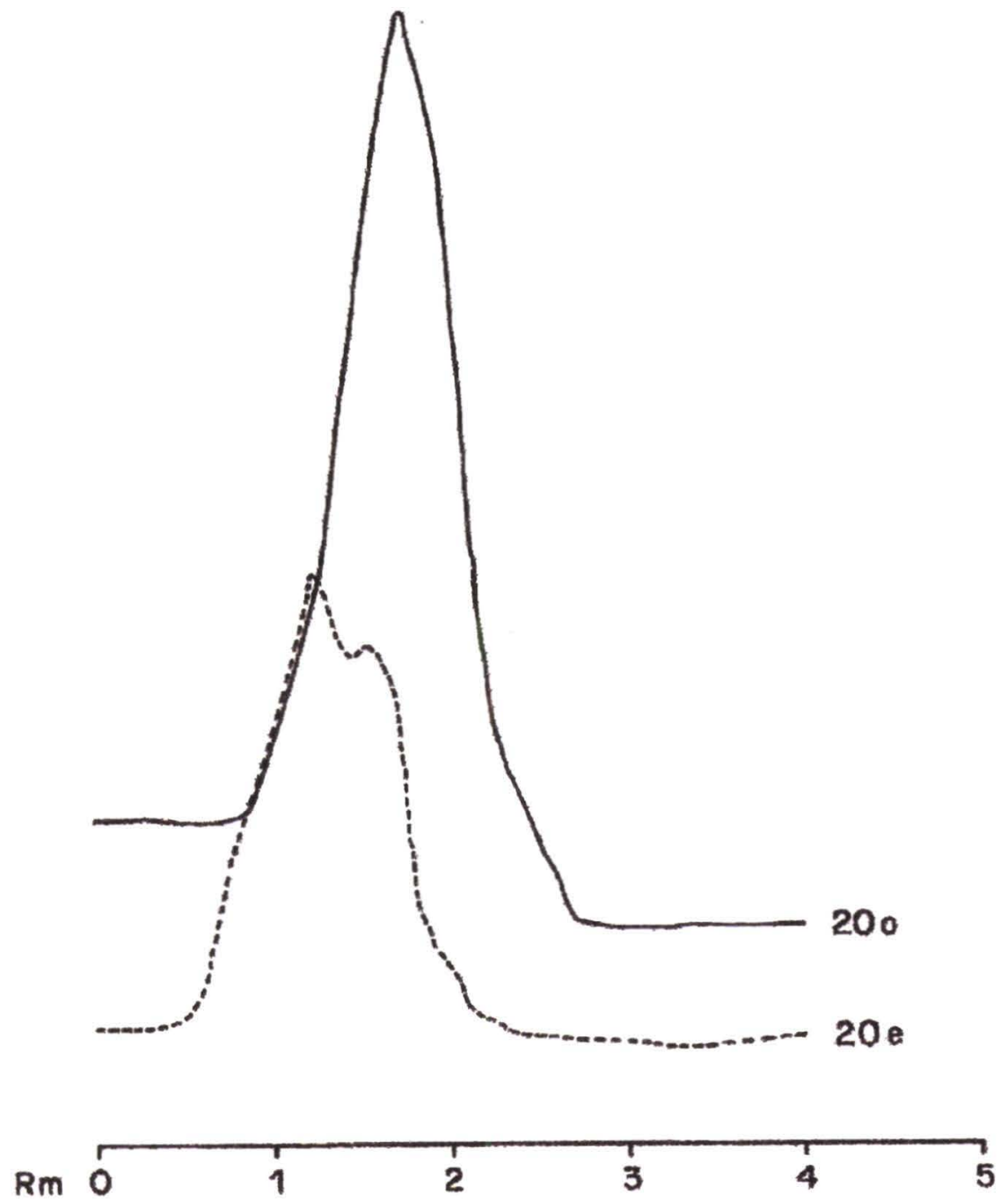

Figura 19. Densitometria e gráfico da migração eletroforética do gel de poliacrilamida, corado para esterase, da cepa $n^{\circ} 20$ de $C$. perfringens de teste isolada, na sua forma original $\left(20_{0}\right)$ e exaltada $\left(20_{\mathrm{e}}\right)$. São Paulo, 1997. 

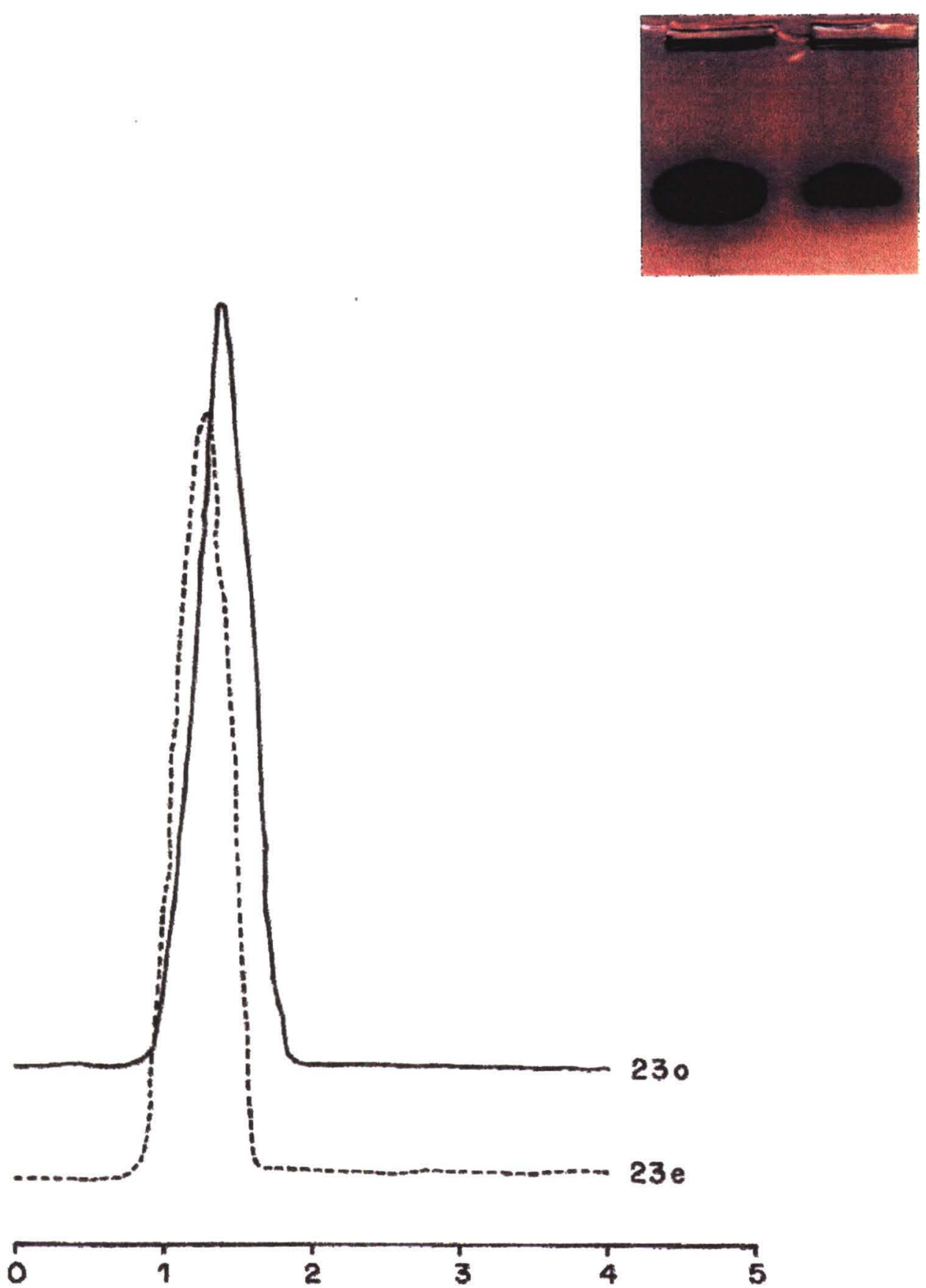

Figura 20. Densitometria e gráfico da migração eletroforética do gel de poliacrilamida, corado para esterase, da cepa $n^{\circ} 23$ de $C$. perfringens de teste isolada, na sua forma original $\left(23_{0}\right)$ e exaltada (23.). São Paulo, 1997. 

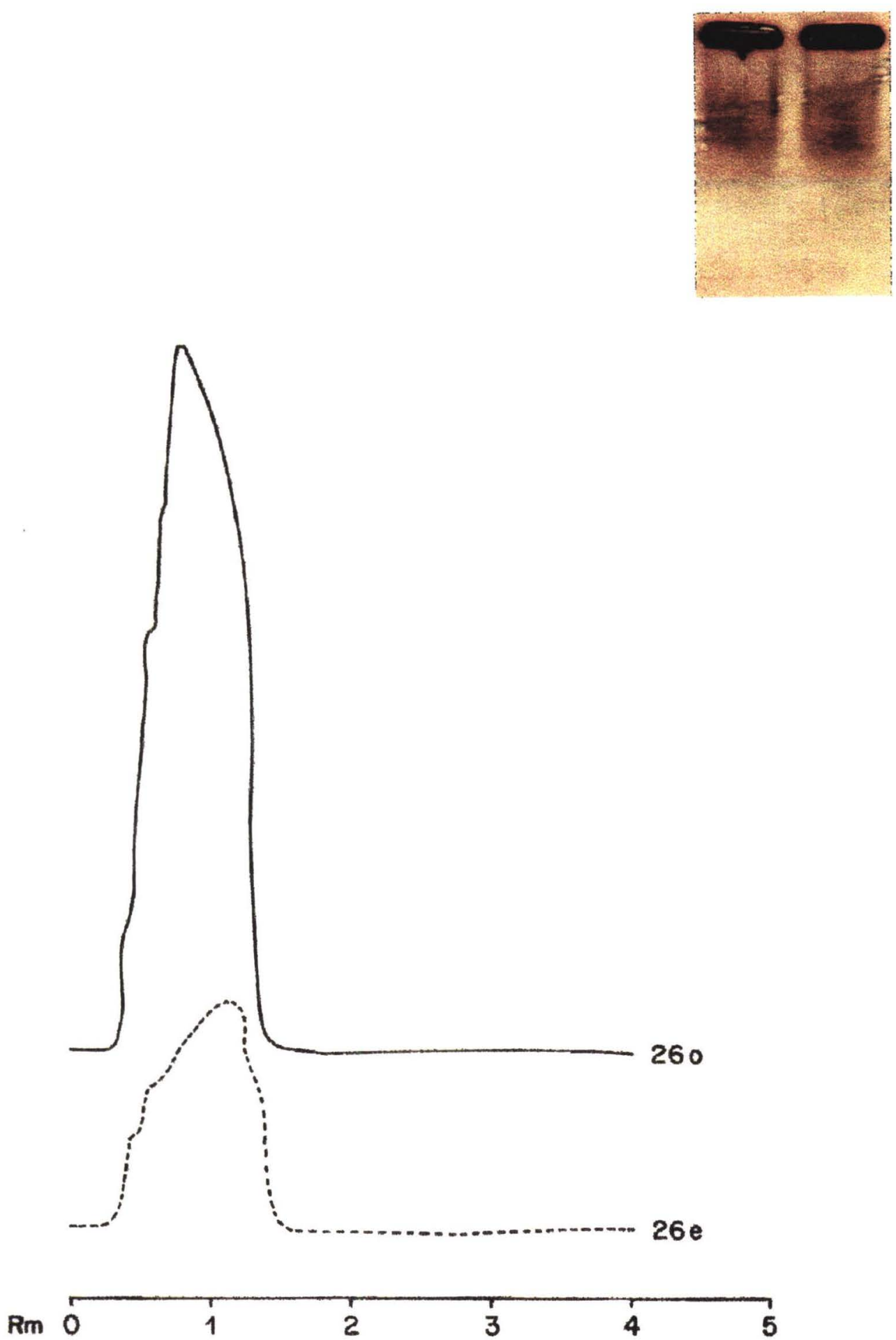

Figura 21. Densitometria e gráfico da migração eletroforética do gel de poliacrilamida, corado para esterase, da cepa $n^{\circ} 26$ de $C$. perfringens de teste isolada, na sua forma original $\left(26_{0}\right)$ e exaltada (26e). São Paulo, 1997. 

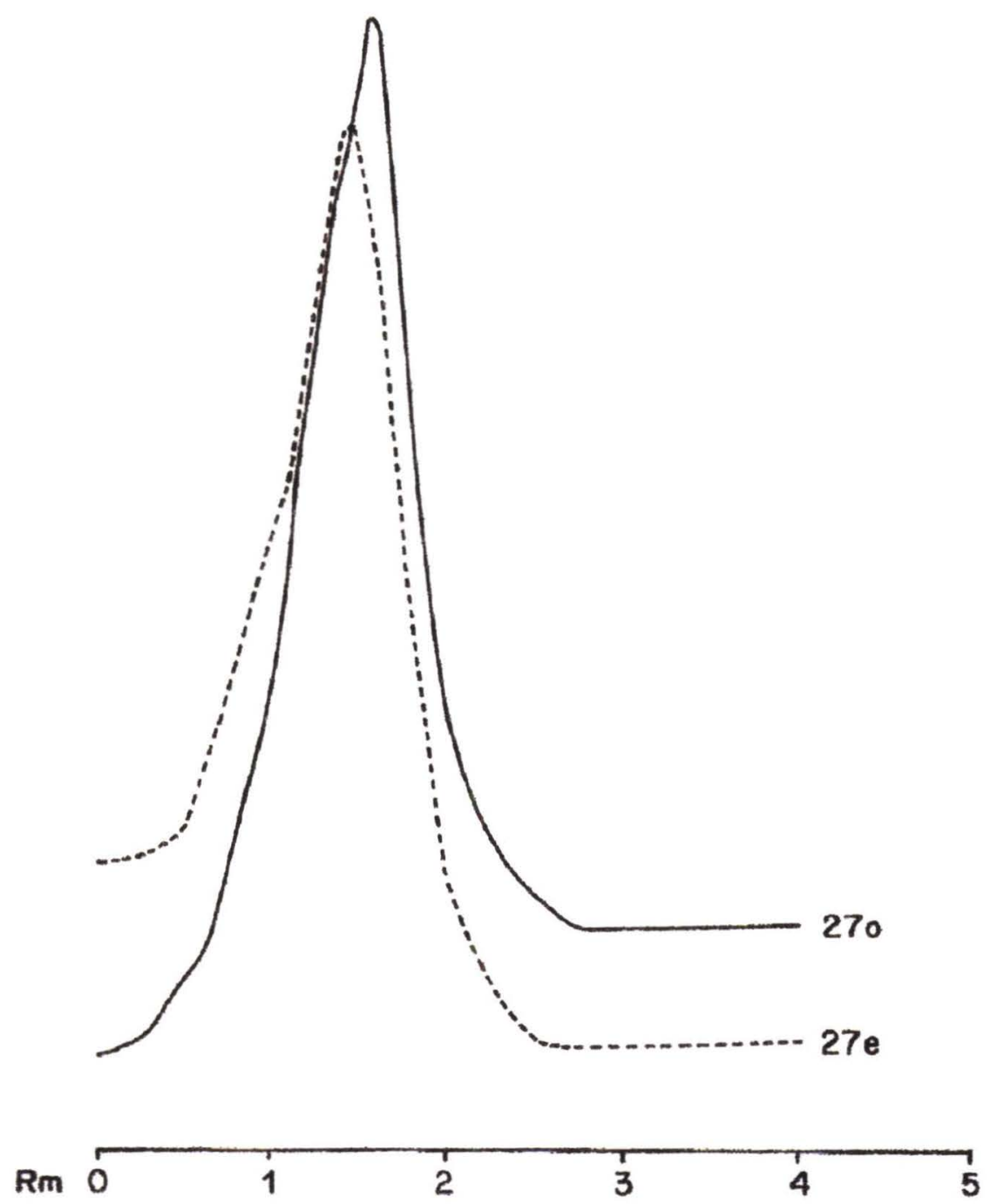

Figura 22. Densitometria e gráfico da migração eletroforética do gel de poliacrilamida, corado para esterase, da cepa $n^{\circ} 27$ de $C$. perfringens de teste isolada, na sua forma original (27o) e exaltada (27e), São Paulo, 1997. 

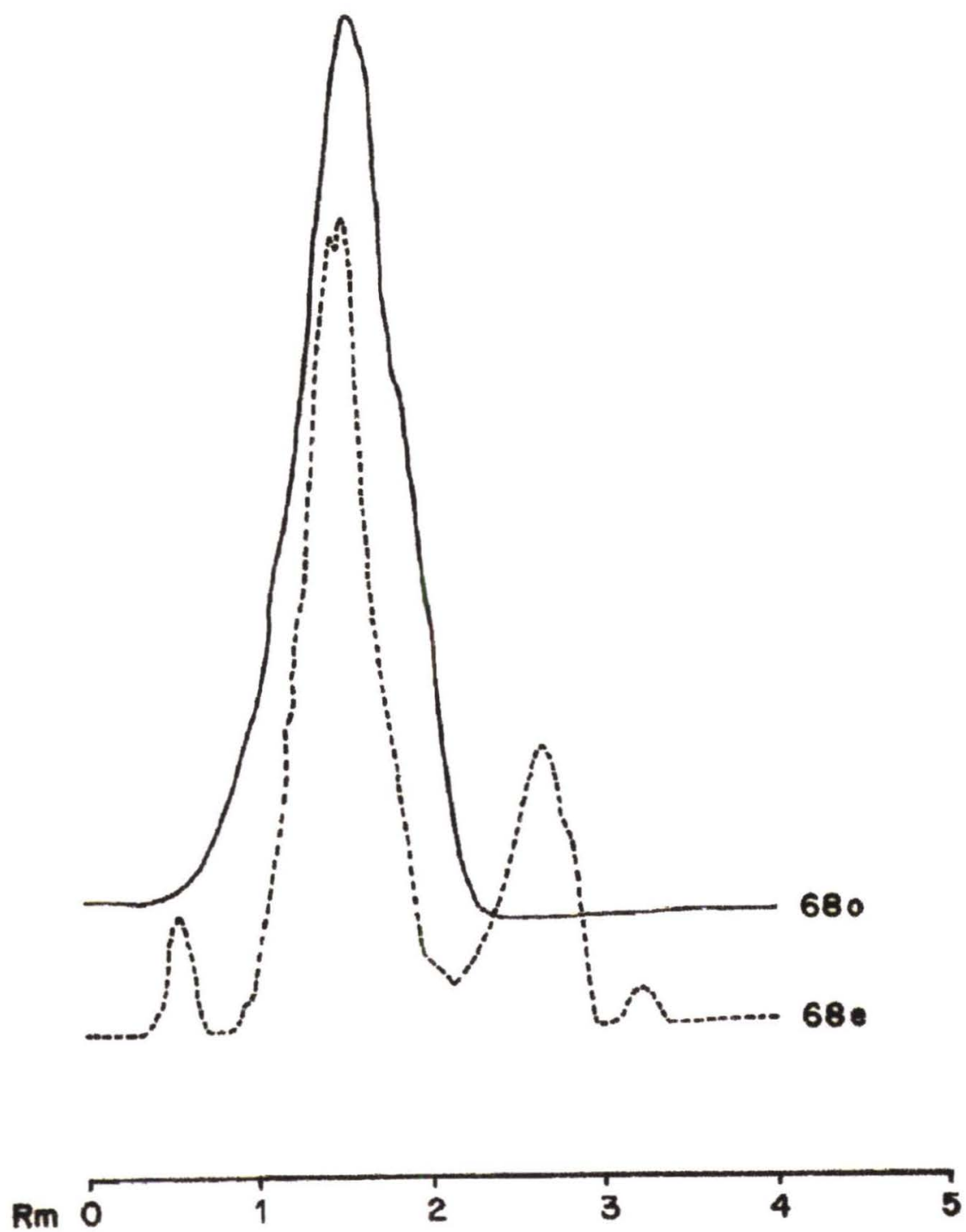

Figura 23. Densitometria e gráfico da migração eletroforética do gel de poliacrilamida, corado para esterase, da cepa $n^{\circ} 68$ de C. perfringens de teste isolada, na sua forma original $\left(68_{0}\right)$ e exaltada $\left(68_{\mathrm{e}}\right)$, São Paulo, 1997. 

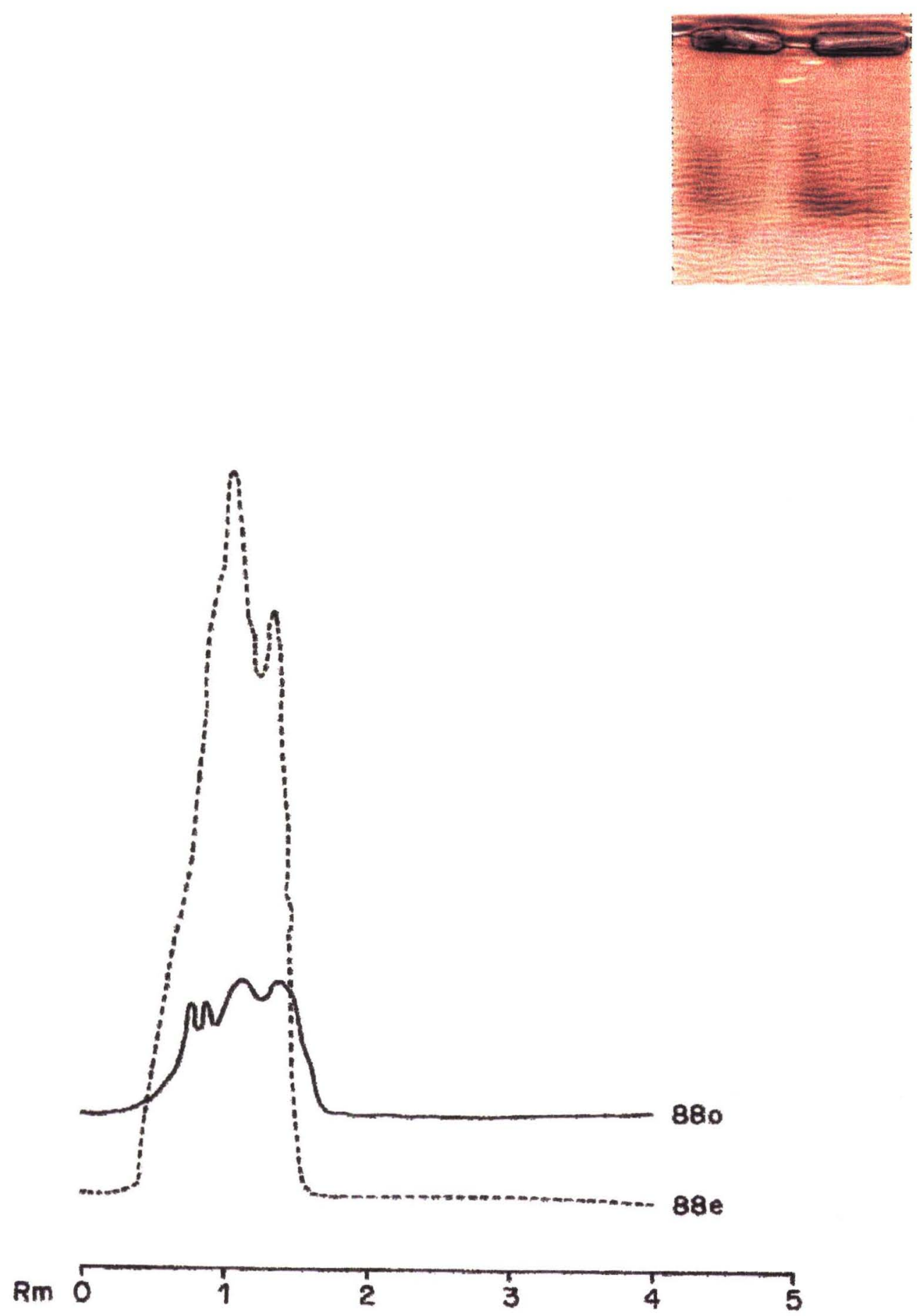

Figura 24. Densitometria e gráfico da migração eletroforética do gel de poliacrilamida, corado para esterase, da cepa $n^{\circ} 88$ de $C$. perfringens de teste isolada, na sua forma original $\left(88_{0}\right)$ e exaltada $\left(88_{\mathrm{e}}\right)$, São Paulo, 1997. 
Tabela 5. Valores da porcentagem de volume, área, média de absorbância e relação absorbância $x$ área apresentados pelas bandas de eletroforese corada para esterase, de cepas de C. perfringens padrão ATCC 3624 tipo A, 3626 tipo $B$, 3628 tipo C, 3629 tipo D e de 10 de teste isoladas nas formas original (o) e com virulência exaltada (e). São Paulo, 1997.

\begin{tabular}{|c|c|c|c|c|c|c|c|c|c|c|c|c|}
\hline \multirow{2}{*}{$\begin{array}{c}\text { Amostra } \\
n^{0}\end{array}$} & \multicolumn{4}{|c|}{ banda 1} & \multicolumn{4}{|c|}{ banda 2} & \multicolumn{4}{|c|}{ banda 3} \\
\hline & vol. $(\%)$ & área $(\mathrm{mm} 2)$ & m. abs. & absxarea & vol. $(\%)$ & área $(\mathrm{mm} 2)$ & m. abs & absxárea & vol. $(\%)$ & área $(\mathrm{mm} 2)$ & m abs & absxárea \\
\hline$A_{0}$ & 16,36 & 59,69 & 0.46 & 27,69 & & & & & & & & \\
\hline$A_{n}$ & 13.12 & 46.81 & 0.47 & 22.17 & & & & & & & & \\
\hline $\mathrm{B}_{\mathrm{A}}$ & 9.35 & 55.50 & 0.28 & 15.81 & 0.94 & 17.08 & 1.59 & 1.59 & & & & \\
\hline $\mathrm{C}_{0}$ & 9,23 & 52,68 & 0,29 & 15,59 & 289 & 27,42 & 0,17 & 4,89 & & & & \\
\hline $\mathrm{C}_{n}$ & 16.58 & 65.77 & 0.42 & 28.02 & & & & & & & & \\
\hline $\mathrm{D}_{u}$ & 9,60 & 60,78 & 0.26 & 16,22 & & & & & & & & \\
\hline D. & 18,94 & 57.55 & 0.55 & 32.02 & & & & & & & & \\
\hline 10 & 2,32 & 23,68 & 0.19 & 4,49 & & & & & & & & \\
\hline 10 & 1.71 & 15.83 & 0.20 & 3.31 & & & & & & & & \\
\hline 11 & 34,07 & 52,24 & 0.53 & 28,12 & & & & & & & & \\
\hline 11. & 14.97 & 18.70 & 0.66 & 12,35 & & & & & & & & \\
\hline 12 & 25,18 & 41,92 & 0,61 & 25,67 & & & & & & & & \\
\hline 12 & 13.13 & 33.44 & 0.40 & 13.38 & & & & & & & & \\
\hline 19 & 6,38 & 44,21 & 0.28 & 12,35 & & & & & & & & \\
\hline 19. & 7.71 & 51.49 & 0.29 & 14.92 & & & & & & & & \\
\hline 20 & 8,75 & 35,36 & 0,25 & 8.91 & & & & & & & & \\
\hline 20 & 13,27 & 24,70 & 0.55 & 13.52 & 866 & 18.51 & 0.41 & 8,83 & & & & \\
\hline 23 & 13,03 & 29,59 & 0,45 & 13,28 & & & & & & & & \\
\hline 23 & 6.64 & 24.17 & 0.28 & 6.77 & & & & & & & & \\
\hline 26. & 43,12 & 21.45 & 0,16 & 3.49 & & & & & & & & \\
\hline 26 & 56,88 & 26.59 & 0.17 & 4.61 & & & & & & & & \\
\hline $27_{0}$ & 4,58 & 27,99 & 0,31 & 8.85 & & & & & & & & \\
\hline 27. & 15.54 & 61.52 & 0.49 & 30,06 & & & & & & & & \\
\hline $68_{0}$ & 19,69 & 39,33 & 0.41 & 16.25 & & & & & & & & \\
\hline 68 & 5.39 & 21.25 & 0,20 & 4.45 & 16.30 & 33.97 & 0.39 & 13.53 & 9,49 & 32.53 & 0.24 & 7.83 \\
\hline $88_{0}$ & 2,26 & 21,51 & 0,20 & 4,37 & & & & & & & & \\
\hline 88. & 3.34 & 18.67 & 0.34 & 6.46 & & & & & & & & \\
\hline
\end{tabular}




\subsection{Sintese de resultados dos ensaios efetuados}

Os Quadros 6, 7, 8 e Tabela 6 foram elaborados para melhor visualização dos resultados.

No Quadro 6 estão reunidos os resultados referentes aos testes de toxigenicidade (Quadro 5), ELISA (Tabela 4) e eletroforese (Figuras 7 a 10) efetuados para as 89 cepas de teste isoladas.

Nos Quadros 7 e 8 são apresentados os resultados obtidos nos testes de toxigenicidade (Quadro 5), ELISA (Tabela 4), eletroforese (Figuras 7 a 10) e dados referentes à origem das cepas (Quadro 4), referindo-se, respectivamente, a amostras de um único animal e de diferentes animais que fossem da mesma origem. Na Tabela 6 é apresentado o número total de cepas identificadas em cada um dos tipos de $C$. perfringens, de acordo com os testes de ELISA e eletroforese realizados com as 89 cepas de teste isoladas.

Com relação a cepas de teste isoladas de diferentes órgãos, de um mesmo animal, Quadro 7, verifica-se que todas as cepas de origem renal (números 16 , 18 e 2) foram toxigênicas e as de rúmen (8, 4 e 20) atoxigênicas. Salienta-se que de 3 animais todas as cepas isoladas testadas $(1,2,30,75),(16,17)$ e $(13,34)$ foram toxigênicas, independentemente do órgão de isolamento, enquanto que para outro animal foram isoladas somente cepas atoxigênicas $(3,4$ e 9). Para 3 outros animais $(7,8),(86,87)$ e $(10,12)$ houve controvérsia nos resultados quando somente dois órgãos foram avaliados, pois em um as cepas foram toxigênicas $(7,87,10)$ enquanto no outro atoxigênicas $(8,86,12)$.

Das cepas correspondentes ao Estado de Mato Grosso (18, 19, 20), duas mostraram-se toxigênicas, sendo uma apenas no sobrenadante não tripsinizado, a outra também no tripsinizado, enquanto a última não apresentou toxigenicidade. Das provenientes de materiais de bovinos da Bahia, as de um animal $(3,4,9)$ eram todas atoxigênicas, enquanto para o outro $(10,12)$, apenas uma determinou morte dos animais. 
Para as amostras oriundas da cidade de Presidente Venceslau (SP) observa-se, nos Quadros 7 e 8 , que todas as cepas $(1,2,30,75,37,39)$ foram toxigênicas, independentemente do órgão de origem.

Da análise do Quadro 8 pode-se verificar que das cepas testadas isoladas de materiais registrados como oriundos da Capital (SP) e de Minas Gerais, a maioria foi atoxigênica, bem como o foram tọdas as da cidade de Rondonópolis (MT). 
Quadro 6. Classificação das 89 cepas de C. perfringens de teste isoladas, baseada nos teste de toxigenicidade (tox.), ELISA e eletroforese corada para esterase (eletro.). São Paulo, 1997.

\begin{tabular}{|c|c|c|c|c|c|c|c|}
\hline \multirow[b]{2}{*}{ amostra } & \multicolumn{3}{|c|}{ testes } & \multirow[b]{2}{*}{ amostra } & \multirow[b]{2}{*}{ tox. } & \multicolumn{2}{|c|}{ testes } \\
\hline & tox. & ELISA & eletro. & & & ELISA & eletro. \\
\hline 1 & + & $D$ & A & 46 & - & $B$ & $A$ \\
\hline 2 & + & B & $\mathrm{B}$ & 47 & - & $D$ & $D$ \\
\hline 3 & - & $A$ & $A$ & 48 & + & $D$ & $A$ \\
\hline 4 & - & $A$ & $A$ & 49 & - & $D$ & C \\
\hline 5 & + & $A$ & $A$ & 50 & - & D & $D$ \\
\hline 6 & - & A & $A$ & 51 & - & $D$ & C \\
\hline 7 & + & $A$ & A & 52 & - & D & $A$ \\
\hline 8 & - & $A$ & $A / D$ & 53 & - & $D$ & D \\
\hline 9 & - & $A$ & A & 54 & - & D & C \\
\hline 10 & + & A & A & 55 & - & D & D \\
\hline 11 & + & $B / D$ & $B / D$ & 56 & - & D & $D$ \\
\hline 12 & - & B & B & 57 & - & $D$ & $D$ \\
\hline 13 & + & $A$ & C & 58 & - & D & D \\
\hline 14 & + & $D$ & C & 59 & + & $D$ & D \\
\hline 15 & + & $\mathrm{B}$ & $B / D$ & 60 & + & $D$ & A \\
\hline 16 & + & $A / D$ & D & 61 & - & B & A \\
\hline 17 & + & $B / D$ & C & 62 & - & $B / D$ & C \\
\hline 18 & + & A & D & 63 & + & $B / D$ & A \\
\hline 19 & + & $A / B$ & D & 64 & + & D & C \\
\hline 20 & - & B & $D$ & 65 & + & $B / D$ & C \\
\hline 21 & - & $A / D$ & C & 66 & - & A & A \\
\hline 22 & + & A & A/B & 67 & + & $D$ & A \\
\hline 23 & - & $A$ & $\mathrm{D}$ & 68 & + & $D$ & A \\
\hline 24 & + & $A$ & $C$ & 69 & + & $D$ & $D$ \\
\hline 25 & + & $A$ & $A$ & 70 & + & $D$ & $D$ \\
\hline 26 & + & A & A & 71 & + & $D$ & A \\
\hline 27 & - & $D$ & A & 72 & - & $D$ & A \\
\hline 28 & + & $A$ & $A$ & 73 & - & $D$ & A \\
\hline 29 & + & A & $A$ & 74 & + & D & $A$ \\
\hline 30 & + & B/D & $A$ & 75 & + & $B / D$ & $A$ \\
\hline 31 & + & $B / D$ & $A$ & 76 & + & $A / B$ & C \\
\hline 32 & - & A & A & 77 & - & A & A \\
\hline 33 & - & $D$ & A & 78 & - & $D$ & C \\
\hline 34 & + & $D$ & $A$ & 79 & - & $D$ & C \\
\hline 35 & + & $D$ & $A$ & 80 & + & A & A \\
\hline 36 & + & A & C & 81 & - & A & C \\
\hline 37 & + & A & A & 82 & - & A & A \\
\hline 38 & + & B & A & 83 & - & $B$ & B \\
\hline 39 & + & A & A & 84 & + & A & A \\
\hline 40 & + & A & C & 85 & + & A & A \\
\hline 41 & - & $A$ & $D$ & 86 & + & $A$ & C \\
\hline 42 & + & B & $D$ & 87 & + & A & $A$ \\
\hline 43 & + & A & $D$ & 88 & + & A & $B$ \\
\hline 44 & + & A & D & 89 & + & $A / D$ & $D$ \\
\hline 45 & + & A & $A / B$ & & & & \\
\hline
\end{tabular}


Quadro 7. Resultados obtidos nos testes de tipagem por ELISA e eletroforese corada para esterase e nos de toxigenicidade de 20 cepas de $C$. perfringens de teste isoladas, relacionando-os ao órgão de isolamento e origem (Estado e cidade), agrupados para um único bovino. São Paulo, 1997.

\begin{tabular}{|c|c|c|c|c|c|c|c|}
\hline origem & & materia & & & testes e & npregad & \\
\hline Estado & cidade & $\operatorname{cepa} n^{\circ}$ & órgão & $\overline{E L I S A}$ & Eletrof. & toxigen & cidade \\
\hline & & & & & & ñ trat. & trat. \\
\hline S. Paulo & Pres. Venceslau & 1 & s. nervoso & D & A & + & + \\
\hline & & 2 & rim & B & A & + & + \\
\hline & & 30 & fígado & $B / D$ & A & + & + \\
\hline & & 75 & músculo & $B / D$ & A & + & + \\
\hline & Sarupiranga & 7 & sangue & A & A & + & - \\
\hline & & 8 & rúmen & A & AVD & - & - \\
\hline & Itú & 16 & rim & AVD & D & + & + \\
\hline & & 17 & figado & $B / D$ & C & + & - \\
\hline & Caiuá & 13 & figado & A & C & + & + \\
\hline & & 34 & intestino & D & A & + & + \\
\hline & Tuiuti & 86 & sangue & A & C & - & - \\
\hline & & 87 & intestino & A & A & + & + \\
\hline Bahia & Prada & 3 & fígado & A & A & - & - \\
\hline & & 4 & rúmen & A & A & - & - \\
\hline & & 9 & intestino & A & A & - & - \\
\hline & Iuiu & 10 & intestino & A & A & + & + \\
\hline & & 12 & figado & B & B & - & - \\
\hline Mato Grosso & Cuiabá & 18 & rim & A & $\mathrm{D}$ & + & - \\
\hline & & 19 & figado & AVB & D & + & + \\
\hline & & 20 & rúmen & & B & - & - \\
\hline
\end{tabular}

$+\quad$ causou morte

- não causou morte

ñ trat. sobrenadante da cultura não tratado por tripsina

trat. sobrenadante da cultura tratado por tripsina 
Quadro 8. Resultados obtidos nos testes de tipagem por ELISA e eletroforese e nos de toxigenicidade de 20 cepas de $C$. perfringens de teste isoladas, relacionando-os ao órgão de isolamento e origem (Estado e cidade), agrupados para bovinos diferentes. São Paulo, 1997.

\begin{tabular}{|c|c|c|c|c|c|c|c|}
\hline \multicolumn{2}{|c|}{ origem } & \multicolumn{2}{|c|}{ material } & \multicolumn{4}{|c|}{ testes empregados } \\
\hline \multirow[t]{2}{*}{ Estado } & cidade & cepa & órgão & ELISA & Eletrof. & Toxigen & idade \\
\hline & & & & & & ñ trat. & trat. \\
\hline \multirow[t]{12}{*}{ S. Paulo } & Pres. Venceslau & 37 & rim & $\bar{A}$ & $A$ & - & + \\
\hline & & 39 & fígado & $\mathrm{B}$ & $A$ & + & - \\
\hline & Pirassununga & 14 & rim & $\bar{D}$ & C & + & + \\
\hline & & 26 & fígado & $A$ & $A$ & + & - \\
\hline & Campinas & 47 & fígado & $\mathrm{D}$ & $\mathrm{D}$ & - & - \\
\hline & & 48 & rúmen & $D$ & $A$ & + & - \\
\hline & & 59 & fígado & D & $\mathrm{D}$ & + & - \\
\hline & Capital & 43 & fígado & $A$ & $\mathrm{D}$ & - & + \\
\hline & & 46 & fígado & $B$ & $A$ & - & - \\
\hline & & 52 & fígado & $\mathrm{D}$ & $\bar{A}$ & - & - \\
\hline & & 56 & fígado & D & D & - & - \\
\hline & & 61 & fígado & $B$ & $A$ & - & - \\
\hline \multirow[t]{5}{*}{ Mato Grosso } & Rondonópolis & 33 & intestino & $D$ & $A$ & - & - \\
\hline & & 79 & figado & $\mathrm{D}$ & $\mathrm{C}$ & - & - \\
\hline & & 85 & intestino & $A$ & $A$ & - & - \\
\hline & Salto do Céu & 74 & rim & $\mathrm{D}$ & $\bar{A}$ & + & + \\
\hline & Pedra Preta & 60 & rim & $D$ & $A$ & + & + \\
\hline \multirow[t]{3}{*}{ Minas Gerais } & B. Horizonte & 11 & fígado & $B / D$ & $\mathrm{~B} / \mathrm{D}$ & - & + \\
\hline & Mira Estrela & 82 & intestino & $A$ & $A$ & - & - \\
\hline & Itapajipe & 83 & intestino & $B$ & $B$ & - & - \\
\hline $\begin{array}{ll}+ & \text { causou } \\
- & \text { não cau } \\
\tilde{n} \text { trat. } & \text { sobrena } \\
\text { trat. } & \text { sobrena }\end{array}$ & $\begin{array}{l}\text { norte } \\
\text { sou morte } \\
\text { dante da cultura } n\end{array}$ & rata & $\begin{array}{l}\text { por tripsina } \\
\text { ripsina }\end{array}$ & & & & \\
\hline
\end{tabular}


Tabela 6. Distribuição do número de cepas de $C$. perfringens de teste isoladas, de materiais de origem bovina, segundo os tipos de acordo com os testes de ELISA e eletroforese corada para esterase. São Paulo, 1997.

\begin{tabular}{ccc}
\hline \multirow{2}{*}{$\begin{array}{c}\text { tipos de toxina } \\
\text { identificados }\end{array}$} & \multicolumn{2}{c}{ testes } \\
\cline { 2 - 3 } & ELISA & Eletroforese \\
\hline A & $36(27)$ & $43(31)$ \\
B & $09(05)$ & $03(02)$ \\
C & $00(-)$ & $18(14)$ \\
D & $31(23)$ & $20(15)$ \\
AB & $02(01)$ & $02(01)$ \\
AVD & $03(02)$ & $01(01)$ \\
C/D & $-(-)$ & $-(-)$ \\
B/D & $08(07)$ & $02(01)$ \\
\hline total & $89(65)$ & $89(65)$ \\
\hline - nenhuma cepa identificada \\
( ) resultados para o Estado de São Paulo
\end{tabular}




\section{DISCUSSÃO}

As doenças determinadas por clostrídios são, ainda hoje, um grande problema económico no Brasil. Apesar delas poderem ser muito bem controladas, quando esquemas vacinais são seguidos com rigor, mortes em rebanhos, particularmente nos bovinos, causadas por $C$. perfringens, vêm sendo responsabilizadas por sérios prejuizos aos agricultores, diminuindo a exportação de carne e a oferta protéica à população. Vale ressaltar que muitas destas mortes não têm sua causa elucidada e quando a têm, o diagnóstico se restringe ao gênero e espécie deste agente bacteriano, porém sem a identificação do seu tipo.

$\mathrm{Na}$ presente investigação, cepas de Clostridium, isoladas de amostras de materiais de necrópsia de bovinos e identificadas bioquimicamente como perfringens, foram estudadas na tentativa de determinar os seus tipos.

Para isto, as 144 cepas classificadas bioquimicamente como C. perfringens, foram inicialmente isoladas por duas caracteristicas básicas: presença de dupla hemólise em ágar sangue e produção de lecitinase em ágar gema de ovo, embora a ICMSF (1996) refira também a existência de colônias com um único halo ou não hemolíticas e PINEGAR \& STRINGER (1977) relatem a ocorrência de cepas fracamente ou não produtoras de lecitinase.

MACFARLANE e cols., (1941) e SALAM \& EL SANOUSI (1991) afirmam a existência de associação entre a produção de alfa toxina e presença de hemólise e também da produção de lecitinase com toxicidade, porém, na prática, verifica-se que muitas cepas não produzem lecitinase ou são falsas produtoras (HANSEN \& ELLIOT, 1980; SALAM \& EL SANOUSI, 1991). A prova de Nagler que caracteriza a espécie perfringens e poderia excluir as cepas falso-positivas (NAKAMURA e cols., 1976; SALAM \& EL SANOUSI, 1991), não foi empregada no 
presente trabalho por não se dispor da antitoxina do tipo A, a qual é fundamental para sua realização.

Outras caracteristicas, como produção de gelatinase, redução de nitrato, motilidade negativa, fermentação da lactose e tumultuosa do leite desnatado foram também consideradas, por constituírem provas bioquimicas que identificam a espécie (MAHONY \& SWANTEE, 1978; TSCHIRDEWAHN e cols., 1991; MAHONY e cols., 1992).

Na área animal, o diagnóstico das enterotoxemias é sempre baseado no histórico, sinais clínicos e achados de necrópsia, mas a análise de laboratório é essencial para a determinação da presença das toxinas $\beta$ e $\varepsilon$ (STERNE \& BATTY, 1975). Em geral a detecção das toxinas de $C$. perfringens em amostras de fezes por ensaio "in vivo" em camundongos, é o padrão para a confirmação do diagnóstico, embora em pesquisas realizadas com ovinos tenha sido detectada a toxina $\varepsilon$, em baixos níveis, em animais sadios e imunizados (BULLEN, 1970). Assim como a toxina $\varepsilon$, a enterotoxina tem sua atividade tóxica aumentada quando tratada por tripsina (OAKLEY \& WARRACK, 1953; GRANUM e cols., 1981; UEMURA e cols., 1986), enquanto a $\beta$ é inativada pelo mesmo tratamento (DOWELL \& HAWKINS, 1973). Isto pode explicar, como pode ser depreendido da análise do Quadro 5,.os $9 \%$ de cepas toxigênicas encontradas apenas após o tratamento por tripsina e os $15,7 \%$ que perderam a toxigenicidade com o mesmo tratamento.

Neste Quadro também se observa, grande variaçāo quanto à presença de toxina nos sobrenadantes das culturas, nas suas formas nāo ativada e/ou ativada por tripsina ou a ausència de toxina nos sobrenadantes sem este tratamento e presença ou ausência após o tratamento. Salienta-se que na inoculação de camundongos, com os sobrenadantes das culturas das cepas isoladas, a intenção foi verificar a presença de toxina, porém sem identificá-la quanto ao tipo, dada a não disponibilidade dos $A_{s}$ especificos. 
Associando-se os dados dos Quadros 4 e 5, pode-se observar que cepas toxigênicas foram detectadas em qualquer que fosse o órgão de origem. Das 14 cepas de origem renal, $11(78,6 \%)$ foram toxigênicas. Das cepas toxigênicas, 9 $(81,8 \%)$, apresentaram toxicidade para os inóculos em suas formas não tratada e tratada por tripsina, $1(9,0 \%)$ apenas para a forma sem tratamento e $1(9,0 \%)$ somente para a tratada. Três $(27,3 \%)$ cepas revelaram-se negativas para o teste. Das 18 cepas isoladas de intestino, $11(61,1 \%)$ mostraram-se toxigênicas, sendo 7 $(38,9 \%)$ com e sem tratamento, $2(11,1 \%)$ só na forma não tratada e $2(11,1 \%)$ somente após o tratamento. Para as 33 cepas isoladas de fígado, verificou-se que $17(51,5 \%)$ eram toxigênicas, sendo $7(21,2 \%)$, em ambas as formas tratada e não tratada, $6(18,2 \%)$ somente sem tripsinização e $4(12,1 \%)$ somente após tripsinização (Quadro 5)

Verifica-se ainda no Quadro 5, que das 89 cepas isoladas testadas, 51 $(57,3 \%)$, constituindo a maioria, revelaram-se produtoras de toxina sendo, portanto, potencialmente patogênicas, observação esta concordante com os dados de TSAl e cols., (1974), que relatam, no Canadá, $60 \%$ de toxigenicidade em cepas de $C$. perfringens isoladas de material bovino de matadouro.

Denota-se, associando-se os dados dos Quadros 4 e 5 que a maior porcentagem de cepas toxigèncias foi verificada nas amostras renais (11 em 14) $78,6 \%$, seguida pelo conteúdo intestinal (10 em 18) $55,5 \%$ e figado (17 em 33 ) $51,5 \%$. O ambiente renal deve representar algum papel na expressão da toxigenicidade das cepas de C. perfringens além do fato de a toxina ter esta via de excreção

A análise dos resultados sumariados nos quadros 7 e 8 revela variação de toxigenicidade nas diferentes amostras estudadas. De acordo com HOLLIDAY (1985) o grau de encapsulamento tem sido associado à patogenicidade, o que é explicado pela observação de maior toxigenicidade com isolados clinicos do que com cepas de origem fecal e de ambiente e, também, pelo fato de que cepas mantidas por muito tempo ou que tenham sofrido muitas passagens em meios 
artificiais, perdem a cápsula e se tornam rugosas (HUGHES e cols., 1976). Estas observaçōes justificam, de certa forma, a ocorrência, em um mesmo animal, de cepas toxigênicas em um órgão e atoxigênicas no outro e o fato de cepas atoxigênicas passarem a apresentar toxigenicidade após a exaltação de sua virulência, ambos também verificados neste ensaio. Apesar disto, em relação à enterotoxina, MAHONY e cols., (1992) demonstraram que a habilidade de uma cepa produzir a toxina "in vitro", não reflete a capacidade de produzi-la "in vivo", porém, sua detecção, em cultivos de laboratório mantidos sob as mesmas condições, pode determinar o potencial toxigênico de uma determinada cepa.

O esquema de tipificação sorológica, para o $C$. perfringens, foi inicialmente desenvolvido na Inglaterra, empregando 8 cepas e tendo como objetivo apenas o tipo A (HOBBS e cols., 1953). HUGHES e cols., (1976) preconizaram só para o tipo $A$ um esquema com $57 A_{s}$ e obtiveram índices de tipificação de $65 \%$ nas investigações de surtos de toxinfecção alimentar e de $59 \%$ em casos de gangrena gasosa e outras infecçōes causadas por este agente. KLOTZ (1965) e WILLIS (1969) enfrentaram dificuldades utilizando dezenas de $A_{s}$, enquanto STRINGER \& cols., (1980) visando melhores índices de tipificação, empregaram esquema composto por $A_{s}$ para 75 amostras inglesas e para 68 americanas e japonesas. No entanto, segundo WATSON (1985), em levantamentos epidemiológicos seria necessário, o emprego de pelo menos 139 diferentes $A_{s}$ (75 cepas inglesas e 64 japonesas), não disponiveis comercialmente e ainda, necessário haver condições para o preparo de outros, com cepas não tipificáveis por este conjunto. 0 "International Serotyping Scheme" relata $82 \%$ de sucesso na classificação de cepas de $C$. perfringens com $143 \mathrm{~A}_{\mathrm{s}}$ (ICMSF, 1996).

Deve-se considerar, também, a existência de variantes atoxigênicas ou que perderam sua toxigenicidade (DALLING \& ROSS, 1938; BUDDLE, 1954), além do fato de que os testes sorológicos, relacionados às toxinas, não mostram nítida separação entre os vários tipos de C. perfringens (SERRANO \& SCHNEIDER, 1978). 
Para o gênero Clostridium, testes de ELISA vêm sendo utilizados para detecção de toxinas B do C. botulinum (KOSAKI e cols., 1979), A do C. difficile (MCCLANE \& STROUSE, 1984), $\beta$ (MARTIN e cols.,1988), $\varepsilon$ (WEDDELL \& WORTHINGTON, 1984; NAYLOR e cols., 1987) e enterotoxina (DOBOSCH, 1984; MCCLANE \& STROUSE, 1984; NIILO \& CHO, 1984; NOTERMANS e cols. 1984; BARTHOLOMEW e cols., 1985; WINSATT e cols., 1986; UEMURA e cols., 1992) do C. perfringens. Estes ensaios foram desenvolvidos com o objetivo de se dispor de um teste, "in vitro", mais simples, rápido e acurado do que os testes sorológicos realizados "in vivo" (McDONEL, 1980; WEDDELL \& WORTHINGTON, 1984; MARTIN e cols., 1988).

Um ensaio que não exigisse o emprego de antitoxinas, as quais não são disponiveis comercialmente e pelas dificuldades existentes na sua produção e purificação justificaram a tentativa de introdução de uma nova técnica de ELISA para identificar os tipos sorológicos de $C$. perfringens. Para a execução deste estudo foram produzidos anti-soros, com base nas pesquisas de MAHONY e cols. (1992), contra as células bacterianas dos quatro tipos padrão ATCC de $C$. perfringens. $O$ tipo $E$ não foi incluído, pois raramente é agente causal de enfermidade (MÖLLBY e cols., 1976).

Estudos relacionados à química e imunologia mostram que antígenos tipo-específicos, nos quais a sorologia de $C$. perfringens é baseada, estão localizados em polissacarideos capsulares (CHERNIAK \& HENDERSON, 1972; LEE \& CHERNIAK, 1974; PAINE \& CHERNIAK, 1975). Assim, reaçōes cruzadas entre amostras podem ocorrer e se devem à presença de polissacarideos grupoespecificos que são perdidos quando as cepas se tornam rugosas (CHERNIAK \& HENDERSON (1972). O elevado indice de reações cruzadas observado em relação as cepas estudadas (Tabelas 3 e 4 ) pode, em parte, ser justificado pelo emprego de cepas de teste não isoladas em um único momento e que eram mantidas em meios artificiais, ambiente apropriado para induzir alterações em diferentes antigenos. 
A sorologia utilizada nesta investigação, contra os 4 tipos de $C$. perfringens (A, B, C e D), pelo ELISA, apresentou reações cruzadas, não permitindo portanto, a separação entre os tipos da espécie (Tabelas 3 e 4). 0 ensaio permitiu somente a confirmação da identificação do agente. Estes resultados são compativeis com os da literatura que não o consideram um teste suficientemente discriminatório para os tipos.

Analisando-se a Tabela 3, pode-se verificar que o $A_{s}$ para o tipo $A$ reagiu melhor com o antígeno do tipo A (valor de absorbância $=222$ ), em relação ao do tipo $D$ (valor de absorbância $=191)$. O $A_{s}$ para o tipo $B$ apresentou identidade com 0 antigeno do tipo $D$ (valor de absorbância $=319$ ), seguido do $A$ (valor de absorbância = 299), em relação ao próprio (280). O As para o tipo C identificou melhor o tipo $D$ (valor de absorbância $=360$ ), seguido do próprio $C(344)$. O As para o tipo $D$, com o antigeno do mesmo tipo (valor de absorbância $=507$ ), porém com pequena diferença em relação ao apresentado para o antígeno A (504). Assim verifica-se que estes $A_{s}$, realmente, não são especificos. Estes resultados sugerem que as estruturas antigênicas das cepas dos quatro tipos ( $A, B, C$ e $D)$ devem apresentar substâncias químicas comuns, observadas nas reações cruzadas. Salienta-se que a partir destes resultados poder-se-ia realizar o teste de adsorção em lâmina, a fim de eliminar as reações cruzadas, entretanto, substâncias químicas com radicais comuns ou próximos, não permitiriam melhores resultados (VOLLER e cols., 1976). Testando as cepas isoladas verifica-se, pela Tabela 4, que os anti-soros A e D foram os que apresentaram maiores títulos, não permitindo, no entanto, a classificação dos diferentes tipos de $C$. perfringens.

O teste de ELISA, empregando toxinas, apesar de não específico, quanto ao tipo, é bastante sensivel na sua quantificação, pois mede niveis de toxina ativa e inativada e em quantidades subletais (NOTERMANS e cols., 1984; WIMSATT e cols., 1986; EL-IDRISSI \& WARD, 1992a, b), sendo portanto útil para cepas de $C$. perfringens pouco produtoras de toxina. $\dot{E}$, ainda, indicado para estudos em grande escala relativos ao diagnóstico e à pesquisa, uma vez que seus resultados são especificos, não subjetivos e obtidos em 24 horas, (McCLANE \& STROUSE, 1984; 
BARTHOLOMEW e cols., 1985; BERRY e cols., 1988; UEMURA e cols., 1992), apresentando porém como séria restrição a não disponibilidade comercial das antitoxinas.

Os mesmos $A_{s}$ obtidos na imunização de coelhos quando testados por prova de imunodifusão não apresentaram nenhuma linha de precipitação, provavelmente, porque os seus títulos estavam em nivel muito baixo para serem detectados por este método.

Segundo vários autores os testes bioquímicos e sorológicos convencionais usados, rotineiramente, para 0 isolamento e identificação de $C$. perfringens, são inadequados para identificar satisfatoriamente, quanto aos tipos, todas as cepas (HANSEN \& ELLIOTT, 1980; SALAM \& EL SANOUSI, 1991).

A variação isoenzimática, também, tem sido usada para determinar a taxonomia de microrganismos quando as características morfológicas não são distintas e isto só é possivel porque as isoenzimas são inerentes ao indivíduo e não são afetadas diretamente por fatores ambientais $(\mathrm{BACH}, 1991)$.

A análise de proteinas e de padrões enzimáticos por eletroforese, constitui valioso método na determinação de componentes genéticos e fisiológicos do hospedeiro e do patógeno (ALFENAS, 1984). Para isto é necessário a obtenção de teor considerável de proteínas, o que vem sendo obtido, na área vegetal, pela trituração dos extratos dos patógenos com $\mathrm{N}_{2}$ líquido (BACH \& GUZZO, 1994). O emprego deste método para $C$. perfringens mostrou-se satisfatório, em detrimento do uso da sonicação (PONS e cols., 1993), processo este que é demorado e exige equipamento e técnica adequados, para que as proteinas não sejam degradadas pelo excesso de aquecimento.

Estudos eletroforéticos podem distinguir bactérias com base na sua mobilidade e nos tipos de esterase, definidos por sua especificidade pelo substrato. Esta técnica é útil na diferenciação entre espécies, apresenta a vantagem de não 
requerer reagentes especificos e de difícil disponibilidade, além de permitir analisar em uma corrida de apenas 3 horas, vários extratos (GOULLET \& PICARD, 1990; PONS e cols., 1993), dependendo da quantidade de poços empregada na placa. Apresenta ainda como vantagem, $\circ$ fato de poder analisar amostras de diferentes fontes, ou sejam, humanas e animais, entre outras. Enfim, a tipificação de $C$. perfringens por meio de eletroforese de esterases pode ser um marco em análises aplicadas à epidemiologia e ecologia (PONS e cols., 1993).

Diferentes autores estudando extratos livres de células bacterianas verificaram que esterases permitem a diferenciação de sorotipos de $B$. cereus (BAILLIE \& NORRIS (1963), B. thuringiensis (NORRIS, 1962,1964) e de espécies de Mycobacterium (CANN \& WILLOX, 1965).

Segundo Pons e cols. (1993) a eletroforese corada para esterase permitiu o estabelecimento de padrōes para cepas de $C$ perfringens originárias de diferentes espécies animais. Neste estudo a mesma técnica foi adotada, estabelecendo-se como parâmetros os tipos sorológicos padrão (ATCC) A, B, C e D e estes valores definidos para uma única espécie animal (bovina). Assim a análise das isoenzimas de esterase apresentadas pela eletroforese, propiciou a separação entre os tipos de C. perfringens que apresentou $94,4 \%$ de definição.

O resultado da eletroforese corada para esterase (Figuras 1 a $10 \mathrm{e}$ Tabela 2) mostrou a presença de bandas características para cada um dos padrões ATCC (Figura 1). Estas bandas, apresentaram valores distintos de Rm, considerados marcadores dos diferentes tipos, permitindo compará-los com os apresentados para cada uma das cepas isoladas testadas (Figura 2). Das 89 cepas isoladas em teste (Figura 3 a 10 e Tabela 2), 43 (48,3\%), foram caracterizadas como do tipo eletroforético A, $20(22,5 \%)$ como D, $18(20,2 \%)$ como C e $3(3,4 \%)$ como B. As cinco cepas $(5,6 \%)$ que por este teste foram classificadas em dois tipos, sugerem a presença de mais de um tipo de $C$. perfringens, o que pela coloração de Gram e pelo bioquimismo, não seriam detectados, dado que ambos se comportariam igualmente nestas provas. 
A eletroforese específica para esterase, das cepas padrão e de teste nas suas formas original e com virulência exaltada, demonstrou variação nas bandas apresentadas para as cepas padrão tipos $\mathrm{B}$ e $\mathrm{C}$ e de teste números 20 e 68 . A cepa do tipo $B$ padrão apresentou mais uma banda na sua forma exaltada enquanto a do tipo $C$ que na sua forma original mostrou duas bandas, passou a revelar apenas uma. As cepas 20 e 68 de teste isoladas, nas formas exaltadas passaram a apresentar, respectivamente, duas e três bandas.

Associando-se o que ocorreu na prova de eletroforese para as cepas que tiveram sua virulência exaltada (Figuras 11 a 24) pode-se inferir que as alterações observadas nas bandas apresentadas pelas cepas com virulência exaltada comparadas com as não exaltadas, devem estar relacionadas à presença de polissacarídeos capsulares.

As bactérias possuem ampla variedade de proteinas extracelulares e enzimas que, por si só, não possuem toxicidade. Enzimas degradativas são produzidas por bactérias patogênicas, porém poucas destas substâncias são diretamente responsáveis pela patogenicidade. Devem portanto, ser categorizadas, mais do que toxinas, como fatores auxiliares potenciais de virulência (MICKELSON, 1970).

Os exopolissacarídeos (EPS), de acordo com CALVERT e cols., (1978) e DAZZO (1979), são moléculas antigênicas e podem estar relacionados à patogenicidade (SUTTON \& WILLIAMS, 1970; NIEPOLD \& HUBER, 1988). Para BACH \& GUZZO (1994), EPS encontrados em culturas de bactérias fitopatogênicas são responsáveis pela antigenicidade. No presente estudo parecem estar influindo na patogenicidade dado que as cepas que produziram morte, quando o inóculo foi proveniente da extração de proteina, foram as mesmas que a determinaram para referidos valores de EPS. 
O método de extração de EPS demonstrou ser sensivel, o bastante, para detectar niveis consideráveis de carboidratos nos sobrenadantes das culturas das cepas de $C$. perfringens isoladas, embora pequenos niveis de proteína ainda estivessem presentes (Tabela 1).

Comparando-se os dados da Tabela 1 com os do Quadro 5 verifica-se que, muito provavelmente, a toxigenicidade revelada pela morte dos animais deva estar relacionada, muito mais com o teor de proteína do que com o de carboidrato, uma vez que para as cepas de números $1,2,18,19,24,29,59,64,74,75,76$ e 87 houve concordância quanto a mortalidade, em ambas as formas de deteç̧ão (sobrenadante de cultura e EPS).

A relação carboidrato/proteína não parece ter-se revelado importante, porque nas amostras que não causaram a morte de camundongos estes valores variaram entre 0,00 e $64,40 \mathrm{mg} / \mathrm{mL}$, estando portanto incluídas nesta faixa as que determinaram a morte destes animais, cujos valores estão entre 7,75 e $14,75 \mathrm{mg} / \mathrm{mL}$. Os valores encontrados para carboidratos, $0,66-4,75 \mathrm{mg} / \mathrm{mL}$, também estavam dentro dos parâmetros que causaram morte $(0,31-0,59 \mathrm{mg} / \mathrm{mL})$. Porém, no que se refere às proteinas, os valores encontrados na extração de EPS revelaram-se entre 0,05 e $0,36 \mathrm{mg} / \mathrm{mL}$ para as cepas cujos extratos não determinaram a morte dos camundongos e, em $0,04 \mathrm{mg} / \mathrm{mL}$ para as que causaram a morte dos animais inoculados (Tabela 1).

Analisando-se os dados da Tabela 6, pode-se constatar que, em relação a todas as cepas estudadas, por ambos os testes empregados, o maior número de cepas foi identificado como sendo do tipo $A$ (eletroforese 48,3\%). Em estudo de tipificação por reação em cadeia de polimerase (PCR), realizado na Korea, constatou-se o tipo A também como o mais prevalente entre amostras bovinas e aviárias (YOO e cols., 1997).

Examinando-se $\circ$ Quadro 4 verifica-se que, dentre as 89 cepas estudadas, 0 maior número delas (65) procedeu do Estado de São Paulo. Assim sendo, vale 
considerar que para este Estado o tipo A foi, pela eletroforese, o predominante $(47,7 \%)$ entre as cepas examinadas (Tabela 6$)$.

Observa-se no Quadro 7, que cepas isoladas de diferentes órgãos de um mesmo animal foram identificadas como pertencentes ao mesmo tipo. Salienta-se ainda que o tipo $A$, também foi o predominante entre as cepas provenientes de órgãos de bovinos da Bahia, assim como de São Paulo. Se for considerada apenas a eletroforese, o tipo $D$ foi o mais predominante para as cepas isoladas de materiais provenientes de Mato Grosso.

Vários ensaios têm sido desenvolvidos para identificação de C. perfringens, para HANSEN \& ELLIOT (1980) há que se associar alguns testes visando resultados mais confiáveis. Estes resultados, no entanto, mostram que a técnica de eletroforese corada para esterase permite e tipificação dos tipos circulantes e poderá ser de grande auxilio para as medidas de controle e prevenção das enfermidades veiculadas pelo $C$. perfringens e desta forma aumentar a oferta protéica em carne bovina à medida que se baixa a letalidade por esta causa e diminue-se os riscos de toxinfecções alimentares que têm na carne bovina a fonte de infecção. 


\section{CONCLUSÕES}

1. As cepas de C. perfringens, isoladas de diferentes órgãos de bovinos, apresentaram toxigenicidade variável.

2. Das 89 cepas de $C$. perfringens isoladas de materiais de origem bovina, a sua maioria $(57,3 \%)$ revelou-se toxigênica. $O$ tratamento dos sobrenandantes das culturas com tripsina, influiu na determinação da toxigenicidade das mesmas, pois $9 \%$ delas mostraram-se toxigênicas, somente, após a tripsinização.

3. O teste de ELISA com anti-soros contra os corpos bacterianos de cepas C. perfringens padrão ATCC não mostrou nenhuma definição quanto aos tipos.

4. A eletroforese corada para esterase na tipificação de C. perfringens, mostrou-se eficaz, uma vez que acima de $90 \%$ das 89 cepas estudadas puderam ser classificadas nos diferentes tipos.

5. Dentre as 89 cepas de $C$. perfringens estudadas, pela eletroforese corada para esterase, o tipo $A$ foi o predominante $(48,3 \%)$, seguido pelo tipo $D(22,5 \%)$, independentemente da região de origem das amostras dos órgãos examinados. 


\section{REFERÊNCIAS BIBLIOGRÁFICAS}

ACHALME, M.P. Examen bactériologique d'un cas de rhumatisme articulaire aigu mort de rhumatisme cérébral. C.R. Soc. Biol. (Paris), 43: 651-6, 1891.

ALFENAS, A.C.; JENG, R.; HUBBES, M. Isoenzyme and protein patterns of isolates of Cryphonectria cubensis differing in virulence. Can. J. Bot. Canadá, 62: 1756$62,1984$.

BACH, E.E. Comparação morfológica, patogênica, serológica e eletroforética de Exserohilum turcicum (Pass.) Leonard \& Suggs, isolado de milho, sorgo e capim massambará. Piracicaba, 1991. 136p. [Dissertação de Mestrado - ESALQ].

BACH, E.E.; GUZZO, S.D. Serological relationship and chemical composition of exopolysaccharides (EPS) from different pathotype of Xanthomonas campestris pv. citri and X. campestris pv. manihotis. J. Phytopathol., 141: 1-9, 1994.

BAILLIE, A.; NORRIS, J.R. Studies of enzyme changes during sporulation in Bacillus cereus using starch gel electrophoresis. J. Appl. Bacteriol., 26: 102, 1963.

BALDASSI, L. Isolamento de bactérias do gênero Clostridium e detecção de toxina botulínica a partir de materiais obtidos de bovinos com suspeita clínica de botulismo. São Paulo, 1986. 59p. [Dissertação de Mestrado - Universidade de São Paulo].

BALDASSI, L.; HIPÓLITO, M.; PORTUGAL, M.A.S.C.; CALIL, E.M.B.; MOULIN, A.A.P. Presença de Clostridium perfringens em sistema nervoso central de bovinos apresentando sintomatologia nervosa. In:Congresso Brasileiro de Medicina Veterinária, 21, 1988, Salvador, BA.

BALDASSI, L.; CALIL, E.M.B.; PORTUGAL, M.A.S.C.; MOULIN, A.A.P; MOURÃO, M.A.F. Morte súbita de caprinos por enterotoxemia. Braz. J. vet. Res. anim. Sci., 32: 109-113, 1995. 
BALLOWS, A. Anaerobic bacteria perspectives. In: Anaerobic bacteria: role in disease. BALLOWS, A.; DeHAAN, R.; DOWELL Jr., V.R.; GUZE , L. B. Springfield. Charles C. Thomas. 1975. p. 9-20.

BARTHOLOMEW, B.A.; STRINGER, M.F. Observations on the purification of Clostridium perfringens type $A$ enterotoxin and the production of a specific antiserum. FEMS Microbiol., Lett. 18: 43-8, 1983.

BARTHOLOMEW, B.A.; STRINGER, M.F.; WATSON, G.N.; GILBRT, R.J. Development and application of an enzyme-linked immunosorbent assay for Clostridium perfringens type A enterotoxin. J. Clin. Pathol., 38: 222-8, 1985.

BATTY, I.; WALKER, P.D. Differentiation of Clostridium septicum and Clostridium chauvoei by the use of fluorescent labelled antibodies. J. Pathol. Bacteriol., 85 (2): 517-521, 1963.

BAYER, A.S.; NELSON, S.C.; GALPIN, J.E.; CHOW, A.W.; GUZE, L.B. Necrotizing pneumonia and empyema due to Clostridium perfringens. Report and review of the literature. Am. J. Med., 59: 851-9, 1975.

BEAN, N.H.; GRIFFIN, P.M. Foodborne disease outbreaks in the United States, 1973-1987, pathogens, vehicles and trends. J. Food Prot., 53: 804-17, 1990.

BENNETTS, H.W. Infectious enterotoxemia (the so-called braxy-like disease) of sheep in western Australia. Bull. Coun. Sci. Indust. Res. Austral., 57, 1932.

BERRY, P.R.; RODHOUSE, J.C.; HUGHES, S.; BARTHOLOMEW, B.A.; GILBERT, R.J. Evaluation of ELISA, RPLA, and Vero cell assays for detecting Clostridium perfringens enterotoxin in faecal specimens. J. Clin. Pathol., 41: 458-61, 1988.

BIDWELL, E. Proteolytic enzimes of Clostridium welchii. Biochem. J., 46: 589-98, 1950.

BOSWORTH, T.J. On a new type of toxin produced by Clostridium welchii. J. Comp. Pathol. Ther., 53: 245-55, 1943. 
BRADFORD, M.M. A rapid and sensitive method for the quantitation of microgram quantities of protein utilizing the principle of protein-dye binding. Anal. Biochem.,72: 248-54, 1976.

BRANDÃO, A.P. Tipificação de amostras de Clostridium perfringens isoladas de fezes humanas e solo. Rio de Janeiro, 1980. 199p. [Dissertaçăo de Mestrado Universidade Federal do Rio de Janeiro].

BROOKS, M.E.; ENTESSAR, F. Anomalous Clostridium welchii type B strains isolated in Iran. Brit. Vet. J., 113: 506-8, 1957.

BROOKS, M.E.; STERNE, M.; WARRACK, G.H. A re-assessment of the criteria caused for type differentiation of Clostridium perfringens. J. Pathol. Bacteriol., 74: 185-95, 1957.

BUDDLE, M.B. Degraded strains of Clostridium welchii type C isolated from sheep in New Zeland. J. Comp. Path. Ther., 64: 223-4, 1954.

BULL, C.G.; PRITCHETT, I.W. Identity of the toxins of different strains of Bacillus welchii and factors influencing their production in vitro. J. Exp. Med., 26: 867-83, 1917.

BULLEN, J.J. Role of toxins in host-parasite relationships. In: Ajl., S.J.; Kadis, S.; Montie, T.C., Microbial toxins. vol.1., New York. Academic Press. 1970. p. 23376.

CABEXAS, M. Determination of the inibitory effect of several compounds on neuraminidases from virus influenza, $V$. cholera and $C$. perfringens. Int. $J$. Biochem., 9: 47-9, 1978

CALVERT., H.E.; LALONDE, M. BHUVANESWARI, T.V; BAUER, W.D. Role of lectins in plant-microorganism interations. 4. Ultrastructural localization of soybean lectin binding sites on Rhizobium japonicum. Can. j. Microbiol., 24: 78593, 1978. 
CANN, D.C.; WILLOX, M.E. Analysis of multimolecular enzymes as an aid to the identification of certain rapidly growing Mycobacteria, using starch gel electrophoresis. J. Appl. Bacteriol., 28: 165, 1965.

CARMAN, R.J. Recurrent diarrhoea in a dog associated with Clostridium perfringens type A. Vet. Rec., 112: 342-3, 1983.

CATO, E.P.; GEORGE, W.L.; FINEGOLD, S.M.Genus Clostridium Prazmowski 1880. In: Bergey's Manual of Systematic Bacteriology, $9^{\text {th }}$ ed., 2. Williams \& Wilkins, Baltimore, p. 1141-200, 1986.

CENTERS FOR DISEASE CONTROL AND PREVENTION. Clostridium perfringens gastroenteritis associated with corned beef served at St. Patrick's Day Meals, Ohio and Virginia, 1993. Morb. Mortal Weekly Rep., 43: 137- 44, 1994.

CHAIN, E.; DUTHIE, E.S. Identity of hialuronidase and spreading factor. Brit. J. Exp. Pathol., 21: 324-38, 1940.

CHAUVEAU, A.; ARLOING, A. Étude expérimentale sur la septicémie gangreneuse. Bull acad. méd. (Paris) $2^{\text {me }} .12: 604,1884$.

CHERNIAK, R.; HENDERSON, B.G. Immunochemistry of the capsular polysaccharides from Clostridium perfringens: selected Hobbs strains 1, 5, 9 and 10. Infec. Immun., 6: 32, 1972.

COLLEE, J.G. The nature and properties of the haemagglutinin of Clostridium welchii. J. Pathol. Bacteriol., 81: 297-312, 1961.

COLLEE, J.G. A myxovirus receptor-inactivating agent occurring in cultures of Clostridium welchii. J. Pathol. Bacteriol., 90:1-11, 1965.

CRAIG, J.P.; MILES, A.A. Some properties of the iota-toxin of Clostridium welchii, including its action on capillary permeability. J. Pathol. Bacteriol., 81: 481-93, 1961. 
DALLING, T.; ROSS, H.E. Clostridium welchii: Notes on the relationship between the types of cultures and the production of toxin. J. Comp. Path. Ther., 51: 235-49, 1938.

DAZZO, F.B. Adsorption of microorganisms to roots and other plant surfaces. In: Bitton, G. \& Marshall, K.C. Adsorption of microorganisms to surfaces. New York. Wiley. 1979. p. 253-316.

DISCHE, Z. General color reactions. In: Whistler, R.L.\& Wolfrom, M.L. Methods in carbohydrate chemistry. vol. I New York. Academic Press. 1965. p. 478-81.

DOBOSCH, D. Enzimoinimunoensayo en la detección de enterotoxina de Clostridium perfringens. Rev. Arg. Microbiol., 16 (1): 33-8, 1984.

DOWELL, V.R.; HAWKINS, T.M. Laboratory methods in anaerobic bacteriology. CDC Laboratory manual. D.H.E.W. Publ. $n^{\circ}$ 74-8272. Washington, U.S. Governm. Print. Office. 1973.

DUNCAN, C.L.; STRONG, D.H. lleal loop fluid accumulation and production of diarrhea in rabbits by cell-free products of Clostridium perfringens. J. Bacteriol., 100: 86-94, 1969.

DUNCAN, C.L.; STRONG, D.H.; SEBALD, M. Sporulation and enterotoxin production by mutants of Clostridium perfringens. J. Bacteriol., 110: 378-91, 1972.

ELLNER, V.R.; BOHAN, C.D. Serology of the soluble antigens of Clostridium perfringens types A-F by agar-gel diffusion. J. Bacteriol., 83: 284-96, 1962.

EL-IDRISSI, A.H.; WARD, G.E. Development of double sandwich ELISA for Clostridium perfringens. Vet. Microbiol., 31: 89-99, 1992a.

EL-IDRISSI, A.H.; WARD, G.E. Evaluation of enzyme-lynked immunosorbent assay for diagnosis of Clostridium perfringens enterotoxemias. Vet. Microbiol., 31: 38996, 1992b. 
ESTRADA, A.; BACA, M.E.; TAYLOR, D. Sporulation and enterotoxin production by mutants of Clostridium perfringens type A strains isolated from pig diarrhoea. Rev. Lat-Amer. Microbiol., 31: 45-50, 1989.

ESTY, J.R. The biology of Clostridium welchii. J. Bacteriol., 5: 375-429,1920.

EVANS, D.G. The in-vitro production of alfa-toxin, theta haemolysin and hyaluronidase by strains of Clostridium welchii type $A$, and the relationship of invitro properties to virulence for guinea-pigs. J. Pathol. Bacteriol., 57: 75-85, 1945.

FRASER, A.G. Neuraminidase production by Clostridia. J. Med. Microbiol., 11: 26980,1978

FRASER, A.G.; COLLEE, J.G. The production of neuraminidase by food-poisoning strains of Clostridium welchii (C. perfringens). J. Med. Microbiol., 8: 251-63, 1975

GALE, E. F.; VAN HEYNINGEN, W. E. The effect of the $\mathrm{pH}$ and the presence of glucose during growth on the production of alfa and theta toxins and hyaluronidase by Clostridium welchii. Biochem. J., 36: 624-30, 1942.

GENIGEORGIS, C.; SAKAGUCHI, G.; RIEMANN, H. Assay methods for Clostridium perfringens type A enterotoxin. Appl. Microbiol., 26: 111-5, 1973.

GILLESPIE, J.H.; LANGLEY, C.H. A general model to account for enzyme variation in natural populations. Genetics, 76: 837-84, 1974.

GIUGLIANO, L.G.; STRINGER, M.F.; DRASAR, B.S. Detection of Clostridium perfringens enterotoxin by tissue culture and double-gel diffusion methods. $\mathrm{J}$. Med. Microbiol., 16: 233-7, 1983.

GLENNY, A.T.; BARR, M.; LLEWELLYN-JONES, M.; DALLING, T.; ROSS, H.E. Multiple toxins produced by some organisms of the Clostridium welchii group. $J$. Pathol. Bacteriol., 37: 53-74, 1933. 
GOULLET, PH. Characterization of Serratia odorifera, S. fonticola and S. ficaria by eletrophoretic patterns of their esterases. J. Gen. Microbiol., 127: 161-7, 1981.

GOULLET, PH.; PICARD, B. Distinctive eletrophoretic and isoeletric focusing patterns of esterases from Yersinia enterocolitica and Yersinia pseudotuberculosis. J. Gen. Microbiol., 130: 1471-80, 1984.

GOULLET, PH.; PICARD, B. Characterization of enterobacteria by esterase specificactivity profiles. J. Gen. Microbiol., 136: 431-40, 1990.

GRANUM, P.E.; WHITAKER, J.R.; SKJELKVALE, R. Trypsin activation of enterotoxin from spores of Clostridium perfringens type A. Biochim. Biophys. acta, 668: 32532, 1981.

HALL, I.C. Differentiation and identification of the sporulating anaerobes. J. Infec. Dis., 30: 445-504, 1922.

HANSEN, M.V.; ELLIOTT, L.P. New presumptive identification test for Clostridium perfringens: reverse CAMP test. J. Clin. Microbiol., 12 (4):617-19, 1980.

HATHEWAY, C.L. Toxigenic Clostridia. Clin. Microbiol. Rev., 3 (1):66-98, 1990.

HAUSCHILD, A.H.W. Erythemal activity of the cellular enteropathogenic factor of Clostridium perfringens type A. Can. J. Microbiol., 16: 651-4, 1970.

HAUSCHILD, A.H.W. Clostridium perfringens toxins types B, C, D and E. In: S. Kadis, T.C.; Montie, T.C.; Ajl, S.J. Microbial toxins. vol. II A Bacterial Protein Toxins. New York. Academic Press. 1971. p.159-188.

HAUSCHILD, A.H.W.; HILSHEIMER, R. Purification and characteristics of the enterotoxin of Clostridium perfringens type A. Can. J. Microbiol., 17: 1425-33, 1971.

HENDERSON, D.W. The somatic antigens of the C. welchii group of organisms. J. Hyg. (Cambridge), 40: 501-12, 1940. 
HOBBS, B.C.; OAKLEY, C.L.; WARRACK, G.H.; CRUICKSHANK, J.C. Clostridium welchii food poisoning. J. Hyg., 51: 75-101, 1953.

HOLDEMAN, L.V.; MOORE, W.E.C. Anaerobic Laboratory Manual. $3^{\text {rd }}$ ed. Blacksburg, Virginia. Virginia Polytechnic Institute and State University. 1972. $132 p$.

HOLLIDAY, M.G. Rapid identification of Clostridium perfringens by counterimmunoelectrophoresis. Medical Lab. Sci., 42: 322-5, 1985.

HOLT, J.G.; KRIEG, N.R.; SNEATH, P.H.A.; STALEY, J.T.; WILLIAMS, S.T. Bergey's Manual of Determinative Bacteriology. $9^{\text {th }}$ ed. Williams \& Wilkins. Baltimore. 1994. p. $559-60$.

HOWARD, A. Races serologiques du B. perfringens. Ann. Inst. Pasteur (Paris), 42 : 1403-19, 1928.

HUGHES, J.A; TURNBULL, P.C.B.; STRINGER, M.F. A serotyping system for Clostridium welchii (C. perfringens) type $A$, and studies on the type-specific antigens. J. Med. Microbiol., 9: 475-84, 1976.

INTERNATIONAL COMISSION ON MICROBIOLOGICAL SPECIFICATIONS FOR FOOD OF THE INTERNATIONAL UNION OF BIOLOGICAL SOCIETIES FOR FOODS. Clostridium perfringens. In: James \& James Micro-organisms in foods 5. Microbiological specifications of food pathogens. Londres. Chapman \& Hall. 1996. p. $112-25$.

ISPOLATOVSKAYA, M.V. Type A Clostridium perfringens toxin. In: Kadis, S.; Montie, T.C.; Ajl, S.J. Microbial Toxins. Bacterial Protein Toxins. New York. Academic Press. v.ll A, 1971. p. 109-58.

KLOTZ, A.W. Application of FA techniques to detection of Clostridium perfringens. Public Health Rep., 80: 305-11, 1965. 
KOSAKI, S.; DUFRENNE, J.; HAGENAARS, A.M.; NOTERMANS, S. Enzyme linked immunosorbent assay (ELISA) for the detection of Clostridium botulinum type $B$ toxin. Jpn. J. Med.Sci. Biol., 32: 199-205, 1979.

KULSHRESTHA, S.B.; GULRAJANI, T.S. A note on haemagglutination activity with Clostridium welchii types B and C. Indian J. An. Sci., 43: 664-6, 1972.

LABBE, R.G.; DUNCAN, C.L. Sporulation and enterotoxin production of Clostridium perfringens type $\mathrm{A}$ under controlled $\mathrm{pH}$ and temperature. Can. J. Microbiol., 20 : 1493-501, 1974.

LABBE, R.G.; DUNCAN, C.L. Influence of carbohydrates on growth and sporulation of Clostridium perfringens type A. Appl. Microbiol., 29: 345-51, 1975.

LAEMMLI, U.K. Cleavage of structural proteins during the assembly of the head of bacteriophage $\mathrm{T}_{4}$. Nature, 227: 680-5, 1970.

LARSON, H.E.; BORRIELLO, S.P. Infectious diarrhea due to Clostridium perfringens. J. Infect. Dis., 157: 390-1, 1988.

LEE, L.; CHERNIAK, R. Capsular polysaccharides of Clostridium perfringens: Hobbs 10. Infec. Immun., 9: 318, 1974.

LOGAN, M.A.; TYTELL, A.A.; DANIELSON, I.A.; GRINER, A.M. Production of Clostridium perfringens alpha toxin. J. Immunol., 51: 317-28, 1945.

MACFARLANE, R.G.; OAKLEY, C.L.; ANDERSON, C.G. Haemolysis and the production of opalescence in serum and lecithovitellin by the alpha toxin of $C$. welchii. J. Path. Bact., 52: 99-103, 1941.

MACLENNAN, J.D. Histotoxic clostridial infection of man. Bacteriol. Reviews, 26 (2):177-276, 1962.

MACKAY, N.N.S.; GRUNEBERG, R. N.; HARRIES, B. J.; THOMAS, P. K. Primary Clostridium welchii meningitis. Br. Med. J., 1: 591-2, 1971. 
MACRAE, D.R.; MURRAY, E.G.; GRANT, J.G.; Entero-toxemia in young suckled calves. Vet. Rec., 30: 305-6, 1943.

MAHONY, D.E. Bacteriocin susceptibility of Clostridium perfringens: a provisional typing schema. Appl. Microbiol., 28: 172-6, 1974.

MAHONY, D.E. Bacteriocin, bacteriophage and other epidemiological typing methods for the genus Clostridium. In: Bergan, T.; Norris, J.R. Methods in Microbiology. vol. 13. Academic Press. New York. 1979. p. 1-30.

MAHONY, D.E.; SWANTEE, C.A. Bacteriocin typing of Clostridium perfringens in human feces. J. Clin. Microbiol., 7 (3):307-9, 1978.

MAHONY, D.E.; AHMED, R.; JACKSON, S.G. Multiple typing techniques applied to a Clostridium perfringens food poisoning outbreak. J. Appl. Bacteriol., 72: 309-14, 1992.

MALIWAN, N. Emphysematous cystitis associated with Clostridium perfringens bacteremia. J. Urol., 121: 819-20, 1979.

MARTIN, P.K.; NAYLOR, R.D.; SHARPE, R.T. Detection of Clostridium perfringens $\beta$ toxin by enzyme-linked immunosorbent assay. Res. Vet. Sci., 44: 270-1, 1988.

MCCLANE, B.A.; MCDONEL, J.L. Effects of Clostridium perfringens enterotoxin on morphology, viability and macromolecular synthesis in Vero cells. J. Cell. Physiol., 99:191-200, 1979.

MCCLANE, B.A.; STROUSE, RJ. Rapid detection of Clostridium perfringens type A enterotoxin by ELISA. J. Clin. Microbiol., 19 (2):112-5, 1984.

MCCLEAN, D. A factor in culture filtrates of certain pathogenic bacteria which increases the permeability of the tissues. J. Pathol. Bacteriol., 42: 477, 1936.

MCCLEAN, D.; ROGERS, H.J. Early diagnosis of wound infection with special reference to mixed infection. Lancet, $i: 707,1943$. 
MCCREA, J.F. Modification of red-cell agglutinability by Clostridium welchii toxins. Aust. J. Expt. Biol. Med. Sci., 25:127-36, 1947.

McDONEL, J.L. The molecular mode of action of Clostridium perfringens enterotoxin. Am. J. Clin. Nutr., 32: 210-18, 1979.

McDONEL, J.L. Clostridium perfringens toxins (type A, B, C, D, E). Pharmac. Ther, 10 (3): $617-55,1980$.

McDONEL, J.L. Toxins of Clostridium perfringens types A, B, C, D and E. Dorner, F.; Drews, J. In: Pharmacology of bacterial toxins. New York. Pergamon. 1986. p. 477-517.

MCDONEL, J.L.; MCCLANE, B.A. Binding versus biological activity of Clostridium perfringens enterotoxin in Vero cells. Biochem. Biophys. Res. Commun., 87: 497-504, 1979.

MCDONEL, J.L.; MCCLANE, B.A. Highly sensitive assay for Clostridium perfringens enterotoxin that uses inhibition of plating efficiency of Vero cells grown in culture. J. Clin. Microbiol., 13: 940-6, 1981.

MCEWEN, A.D. B. paludis: a new species of pathogenic anaerobic bacterium. J. Comp. Pathol. Therap., 43: 1-21, 1930.

MEDEIROS, A.E. Once all the world was anaerobic. N. Engl. J. Med., 287: 1041, 1972.

MEDICAL RESEARCH COUNCIL. Report on the anaerobic infections of wounds and the bacteriological and serological problems arising therefrom. Medical Research Council, spec. rep. ser., 39: 1-182, 1919.

MEHTA, R.; NARAYAN, K.G. Haemagglutinin production by enterotoxigenic strains of Clostridium perfringens type A. World J. Microbiol. Biotechnol., 7: 600-2, 1991.

MICKELSON, M.N. Fisiologia de los microorganismos. In: Merchant, I.A. \& Packer, R.A. Bacteriología y Virología Veterinaria. Acribia. Espanha. 1970. p. 40-62. 
MILKMAN, R. Electrophoretic variation in Escherichia coli from natural sources. Science, 182: 1024-6, 1973.

MOHR, J.A.; GRIFFITHS, W.; HOLM, R.; GARCIA-MORAL, C.; FLOURNOY, D.J. Clostridial myonecrosis (gas gangrene) during cephalosporin prophylaxis. J. Am. Med. Assoc., 239: 847-9, 1978.

MÖLLBY, R.; HOLME, T.; NORD, C.-E.; SMYTH, C.J.; WADSTRÖM, T. Production of phospholipase C (alpha-toxin), haemolysins and lethal toxins by Clostridium perfringens types A to D. J. Gen. Microbiol., 96: 137-44, 1976.

NAIK, H.S.; DUNCAN, C.L. Thermal inactivation of Clostridium perfringens enterotoxin. J. Food Prot., 41: 100-3, 1978.

NAKAMURA, S.; SAKURAI, $M$; NISHIDA, $S$.; TATSUKI, T.; YANAGASE, $Y$.; HIGASHI, Y.; AMANO, M. Lecithinase-negative variants of $C$. perfringens: the identify of C. plagarum with C. perfringens. Can. J. Microbiol., 22: 1497-501, 1976

NAYLOR, R.D.; MARTIN, P.K.; SHARPE, R.T. Detection of Clostridium perfringens epsilon toxin by ELISA. Res. vet. Sci., 42: 255-6, 1987.

NIEPOLD, F.; HUBER, S.J. Surface antigens of Pseudomonas syringae pv. syringae are associated with pathogenicity. Physiol. Molec. Plant Pathol., 33: 459-71, 1988.

NIILO, L. Enterotoxin formation by Clostridium perfringens type A studied by the use of fluorescent antibody. Can. J. Microbiol., 23: 908-15, 1977.

NIILO, L. Clostridium perfringens in animal disease a review of current knowledge. Can. Vet. J., 21(5): 141-8, 1980.

NIILO, L.; AVERY, R.J. Bovine enterotoxemia I. Clostridium perfringens types isolated from animal sources in Alberta and Saskatchewan. Can. Vet. J., 4: 31-6, 1963. 
NIILO, L.; CHO, H.J. An enzyme-linked immunosorbent assay for the detection of Clostridium perfringens enterotoxin antibody. Can. J. Comp. Med., 48: 111-2, 1984.

NORRIS, J.R. Electrophoretic analysis of bacterial esterase systems-an aid to taxonomy. J. Gen. Microbiol., 28: vii, 1962.

NORRIS, J.R. Classification of Bacillus thuringiensis. J. Appl. Bacteriol., 27: 439, 1964.

NOTERMANS, S.; HEUVELMAN, C.; BECKERS, H.; UEMURA.T. Evaluation of the ELISA as a tool in diagnosing Clostridium perfringens enterotoxins. Zentralbl. Bakteriol. Mikrobiol. Hyg. Abt. Orig. B., 179: 225-34, 1984.

OAKLEY, C.L. The toxins of Clostridium we/chii. A critical review. Bull. Hyg. (London), 18: $781-806,1943$.

OAKLEY,C.L.; FULTHORPE, A.J. Antigenic analysis by diffusion. J. Pathol. Bacteriol., 65: 49-60, 1953

OAKLEY, C.L.; WARRACK, G.H. Factors affecting the activity of the alfa-toxin of Clostridium welchii. J. Pathol. Bacteriol., 53: 335-70, 1941.

OAKLEY, C.L.; WARRACK, G.H. The ACRA test as a means of estimating hyaluronidase, deoxyribonuclease and their antibodies. J. Pathol. Bacteriol., 63 : 45-55, 1951.

OAKLEY, C.L.; WARRACK, G.H. Routine typing of Clostridium welchii. J. Hyg. (Cambridge), 51: 102-7, 1953.

OAKLEY, C.L.; WARRACK, G.H.; WARREN, M.E. The kappa and lambda antigens of Clostridium welchii. J. Pathol. Bacteriol., 60: 495-503, 1948.

OLIVEIRA, A.R. Considerações sobre anti-soros obtidos pela técnica de injeção de antígeno no linfonódulo. Summa Phytopathologica, Piracicaba, 1: 61-4, 1975. 
ORLANS, E.S.; JONES, V.E. Studies on some soluble antigens of Clostridium welchii types B, C and D. Immunology, 1: 268-90, 1958.

ORR, J.H.; REED, G.B. Serological types of Clostridium perfringens. J. Bacteriol., 40: 441-8, 1940.

PAINE, $\mathrm{H}$; CHERNIAK, $\mathrm{R}$. Composition of the capsular polysaccharides of Clostridium perfringens as a basis for their classification by chemotypes. Can. J. Microbiol., 21: 181, 1975.

PICARD, B.; GOULLET, P. Epidemiological complexity of hospital Aeromonas infections revealed by electrophoretic typing of esterases. Epidemiol. Infec., 98: 5-14, 1987.

PINEGAR; J.A.; STRINGER, M.F. Outbreaks of food poisoning attributed to lecitinase-negative C. welchii. J.Clin. Pathol., 30: 491-2, 1977.

PIVNICK, H.; HABEEB, A.F.S.A.; GORENSTEIN, B.; STUART, P.F.; HAUSCHILD, A.H.W. Effect of $\mathrm{pH}$ on toxinogenesis by Clostridium perfringens type C. Can. J. Microbiol., 10: 329-44, 1964.

PIVNICK, H.; HAUSCHILD, A.H.W.; GORENSTEIN, B.; HABEEB, A.F.S.A. Effect of $\mathrm{pH}$ on toxinogenesis by Clostridium perfringens type D. Can. J. Microbiol., 11: 45-55, 1965.

PONS, J-L.; PICARD, B.; NIEL, P.; LELUAN, G.; GOULLET, P. Esterase electrophoretic polymorphism of human and animal strains of Clostridium perfringens. Appl. Environm. Microbiol., 59 (2): 496-501, 1993.

POXTON, I.R.; BROWN, R. Sodium dodecyl sulphate-polyacrilamide gel electrophoresis of cell-surface proteins as an aid to the identification of the Bacteroides fragilis group. J. Gen. Microbiol., 112: 211-7, 1979. 
REGAN, C.M.; SYED, Q.; TUNSTALL, P.J. A hospital outbreak of Clostridium perfringens food poisoning-implications for food hygiene review in hospital. J. Hosp. Infect., 29: 69-73, 1995.

ROBB-SMITH, A.H.T. Tissue changes induced by Clostridium welchii type A filtrates. Lancet, 2: 362-8, 1945.

ROBERTSON, W. van B.; ROPES, M.W.; BAUER, W. Mucinase: a bacterial enzyme which hydrolyses synovial fluid and other mucins. J. Biol. Chem.,133: 261-76, 1940.

ROBINSON, K. An examination of Corynebacterium spp by gel electrophoresis. J. Appl. Bacteriol., 29(1): 179-84, 1966.

ROGERS, H.J. The complexity of the hyaluronidase produced by micro-organisms. Biochem. J., 42: 633-9, 1948.

ROOD, J.I.; COLE, S.T. Molecular genetics and pathogenesis of $C$. perfringens. Microbiol. Rev., 55(4): 621-48, 1991.

ROSE, A.L.; EDGAR, G. Enterotoxemia jaundice of sheep and cattle. Austral. Vet. J., 12: 212, 1936.

ROSS, H.E.; WARREN, M. E.; BARNES, J. M. Clostridium welchii iota toxin: its activation by trypsin. J. Gen. Microbiol., 3: 148-52, 1949.

SALAM, I.S.A.; EL SANOUSI, S.M. Proposed scheme for isolation and identification os $C$. perfringens and $C$. perfringens-like organisms. Revue Élev. vét. Pays trop., 44 (2): 153-8, 1991.

SATIJA, K.C.; NARAYAN, K.G. Passive bacteriocin typing of strains of Clostridium perfringens type A causing food poisoning for epidemiologic studies. J. Infect. Dis., 142: 899-902, 1980.

SCHILLER, M.; DONNELY, P.J.; MELO, J.C.; RAFF, M.J. Clostridium perfringens septic arthritis. Clin. Orthop., 139: 92-6, 1979. 
SCOTT, H.G.; MAHONY, D.E. Further development of a bacteriocin typing system for Clostridium perfringens. J. Appl. Bacteriol., 53: 363-9, 1982.

SELANDER, R.K.; CAUGANT, D.A.; OCHMAN, H.; MUSSER, J.M.; GILMOUR, M.N.; WHITTAM, T.S. Methods of multilocus enzyme electrophoresis for bacterial population genetics and systematics. Appl. Environ. Microbiol., 51: 873-84, 1986.

SERRANO, A.M.; SCHNEIDER, I.S. New modification of Willis and Hobbs' method for identification of Clostridium perfringens. Appl. Environ. Microbiol., 35: 809-10, 1978.

SHERMAN, S.; KLEIN,S.; MCCLANE, B.A. Clostridium perfringens type A enterotoxin induces tissue damage and fluid accumulation in rabbit ileum. J. Diarrheal Dis. Res., 12: 200-7, 1994.

SIMONDS, J. P. Classification of the Bacillus welchii group of bacteria. J. Infec. Dis., 16: 31-4, 1915.

SMITH,H.W. The bacteriophages of Clostridium perfringens. J. Gen. Microbiol., 21: 622-30, 1959.

SMITH, L. DS. The pathogenic anaerobic bacteria. Springfield (Illinois), Charles C. Thomas Publ., 1975.

SMITH, L.DS.; HOBBS, G. Genus Clostridium Prazmowski, 1880. In R. E. Buchanan \& N. E. Gibbons (co-eds). Bergey's manual of determinative bacteriology. $8^{\text {th }}$ ed.Baltimore, Williams \& Wilkins Co. 1974. p. 551-72.

STARK, R.L.; DUNCAN, C.L. Biological characteristics of Clostridium perfringens type A enterotoxin. Infect. Immun., 4: 89-96, 1971.

STARK, R.L.; DUNCAN, C.L. Transient increase in capillary permeability induced by Clostridium perfringens type A enterotoxin. Infect. Immun., 6: 662-73, 1972.

STERN, M.; WARRACK, G. H. The types of Clostridium perfringens. J. Pathol. Bacteriol., 88: 279-83, 1964. 
STERN, M.; VAN HEYNINGEN, W.E. The clostridia. In: R.J. Dubos \& J. G. Hirsch. Bacterial and mycotic infections of man. $4^{\text {th }}$ ed. Philadelphia, J. B. Lippincott Co. 1965. p. $545-72$.

STERN, G.A.; HODES, B.L.; STOCK, E.L. Clostridium perfringens corneal ulcer. Arch. Ophtalmol., 97: 661-3, 1979.

STERNE, M.; BATTY, I. Pathogenic Clostridia. London. Butterworths. 1975.

STRINGER, M.F.; TURNBULL, P.C.B.; GILBERT, R.J. Application of serological typing to the investigation of outbreaks of Clostridium perfringens food poisoning. 1970-78. J. Hyg. (Cambridge) 84: 443-56, 1980.

STRINGER, M.F.; WATSON, G.N.; GILBERT, R.J. Clostridium perfringens type A: serological typing and methods for the detection of enterotoxin. In: Corry, J.E.L.; Roberts, D.; Skinner, F.A. Isolation and identification methods for food poisoning organisms. London. Academic Press. (Soc. Apl. Bact. Tech. Series n 17). 1982. p. $111-35$.

STROM, A.; DYER, J.K.; MARSH, C; TRIBBLE, J.L. Identification and characterization of species of the family Bacterioidaceae by polyacrylamide gel electrophoresis. J. Dental Res., 35: 252-6, 1976.

SUTTON, J.C.; WILLIAMS, P.H. Comparison of extracellular polysaccharides of Xanthomonas campestris from culture and from infected cabbage leaves. Can. J. Bot., 48: 645-51,1970.

SWINDLEHURST, C.A.; SHAH, H.N.; PARR, C.W.; WILLIAMS, R.A.D. Sodium dodecyl sulphate-polyacrylamide gel electrophoresis of polipeptides from Bacteroides melaninogenicus. J. Appl. Bacteriol., 43: 319-24, 1977.

TSAI, C.; TORRES-ANJEL, M.J.; RIEMANN, H.P. Improved culture techniques and sporulation medium for enterotoxin production by $C$. perfringens type A. J. Formosan Med. Assoc., 73: 404-9, 1974. 
TAYLOR, A.W.; GORDON, W.S. A survey of the types of $C$. welchii present in soil and in the intestinal contents of animals and man. J. Pathol. Bacteriol., 50: 271$277,1940$.

TSCHIRDEWAHN, B.; NOTERMANS, S.; WERNARS, K.; UNTERMAN, F. The presence of enterotoxigenic $C$. perfringens strains in faeces of various animals. Int. J. Food Microbiol., 14: 175-8, 1991.

UEMURA, T.; NAKAHARA, H.; HORIGUCHI, Y.; SAKAGUCHI, G. Trypsinization of derivatives of $C$. perfringens enterotoxin. Lett. Appl. Microbiol., 3: 31-3, 1986.

UEMURA, T.; YOSHITAKE, S.; HU, D.; KAJIKAWA, T. A highly sensitive enzymelinked immunosorbent assay for $C$. perfringens enterotoxin. Lett. Appl. Microbiol., 15: 23-5, 1992.

VAN HEYNINGEN, W.E. The biochemistry of the gas gangrene toxins. 2. Partial purification of the toxins of $C$. welchii type A. Separation of $\alpha$ and $\beta$ toxins. Biochem. J., 35: 1257-69, 1941.

VOLLER, A.; BIDWELL, D.E.; BARTLET, A. Enzyme immunoassays in diagnostic medicine. Bull. World Health Organ., Europa. Flowline Publications. 53: 55-6, 1976.

WARRACK, G.H. Some observations on the typing of Clostridium perfringens. Bull. Off. Int. Epiz., 59: 1393-400, 1963.

WATSON, G.N. The assessment and application of a bacteriocin typing scheme for Clostridium perfringens. J. Hyg., 94: 69-79, 1985.

WEDDELL, W.; WORTHINGTON, R.W. An enzyme labeled immunosorbent assay for measuring $C$. perfringens epsilon toxin in gut contents. N. Z. Vet. J., 33: 36-7, 1984. 
WELCH, W.H.; NUTTALL, G.H.F. A gas-producing bacillus (Bacillus aerogenes capsulatus, nov. spec.) capable of rapid development in the blood-vessels after death. Bull. John Hopkins Hosp., 3: 81-91, 1892.

WILLIS, A.T. Clostridia of wound infection. London, Butterworths, 1969, p.41-156.

WILSDON, M.J. Observations on the classification of Bacillus welchii. Univ. Cambridge Inst. Anim. Pathol., Rep. 8: 53-85, 1931.

WILSDON, M.J. The relationship of Bacillus ovitoxicus (Bennetts) to the Clostridium welchii group. Univ. Cambridge Inst. Anim. Pathol., Rep. 3: 46-51, 1932-1933.

WIMSATT, J.C.; HARMON, S.M.; SHAH, D.B. Detection of C. perfringens enterotoxin in stool specimens and culture supernatants by enzyme-linked immunosorbent assay. Diagn. Microbiol. Infect. Dis., 4: 307-13, 1986.

YAMAKAWA, Y.; ITO, A.; SATO, $H$. Theta-toxin of $C$. perfringens. I. Purification and some properties. Biochim. Biophys. Acta, 494: 301-13, 1977.

YOO, H.S.; LEE, S.U.; PARK, K.Y.; PARK, Y. Molecular typing epidemiological survey of prevalence of $C$. perfringens types by multiplex PCR. J. Clin. Microbiol., 35(1): 228-32, 1997. 


\section{ANEXO}

\section{MEIOS DE CULTURA, REAGENTES E SOLUÇÕES}

\section{Caldo de carne cozida (meio de Tarozzi)}

água de carne:

carne bovina

$500 \mathrm{~g}$

água destilada

$1.000 \mathrm{~mL}$

A carne empregada, livre de tendões aponevroses e gorduras, era passada em moedor de carne, adicionada do volume correspondente de água destilada, e a mistura mantida por cerca de 12 horas a temperatura ambiente. Após fervura por 15 minutos e filtração, em papel de filtro, constituia-se na água de carne.

Caldo simples

água de carne

$1.000 \mathrm{~mL}$

peptona

$10 \mathrm{~g}$

cloreto de sódio

$5 \mathrm{~g}$

Após a completa dissolução dos ingredientes na água de carne, o pH era ajustado entre 7,4 e 7,6 , e a mistura aquecida a $120^{\circ} \mathrm{C}$ por 20 minutos. O meio era então clarificado por passagem em papel de filtro, seu pH ajustado em 7,8 e distribuido em volumes de $10 \mathrm{~mL}$ em tubos de $18 \times 180 \mathrm{~mm}$ que continham cubos de $1,0 \mathrm{~cm}$ de fígado cozido previamente por 30 minutos e cerca de $3,0 \mathrm{~mL}$ de vaselina sólida fundida. Os tubos eram então tampados com buchas de algodão $e$ submetidos a autoclave por $115^{\circ} \mathrm{C}$ por 30 minutos. 


\section{Caldo triptose e extrato de levedura (CTE)}

"triptic soy broth" (difco) $15 \mathrm{~g}$

extrato de levedura

$5 \mathrm{~g}$

água destilada

$1.000 \mathrm{~mL}$

Após a dissolução dos ingredientes, $\circ$ pH da solução era ajustado em 7,2, procedia-se a distribuição de $10 \mathrm{~mL}$ em tubos e $90 \mathrm{~mL}$ em frascos, sendo ambos submetidos a esterilização em autovlave a $121^{\circ} \mathrm{C}$ por 15 minutos.

\section{Tampão Tris-glicina $60 \mathrm{mM}$, pH 8,7}

solução de tris

Tris (hidroximetil-aminometano) $\ldots . . \quad 7,26 \mathrm{~g}$

água destilada ..................... $\quad 1.000 \mathrm{~mL}$

solução de glicina

glicina (ácido amino acético) $\quad \ldots . . .4,50 \mathrm{~g}$

água destilada $\ldots \ldots \ldots \ldots \ldots \ldots \ldots . . . . . .1 .000 \mathrm{~mL}$

Ir colocando a solução de glicina sobre a solução de Tris, de modo a obter $\mathrm{pH} 8,7$.

Manter sob refrigeração 


\section{Reativo de Bradford}

"Comassie blue G" $10 \mathrm{mg}$

etanol $95 \%$ $5 \mathrm{~mL}$

Colocar a mistura em agitador, após a completa dissolução acrescentar, ainda sob agitação, $10 \mathrm{~mL}$ de ácido ortofosfórico $85 \%$, e completar o volume, para $100 \mathrm{~mL}$, com água destilada. Conservar em geladeira por até 15 dias.

\section{Solução salina fosfatada (PBS) $0,05 \mathrm{M}$}

Cloreto de sódio $\left(\mathrm{N}_{\mathrm{a}} \mathrm{Cl}\right)$

$8,0 \mathrm{~g}$

Fosfato de potássio monobásico $\left(\mathrm{KH}_{2} \mathrm{PO}_{4)}\right.$ $0,2 \mathrm{~g}$

Fosfato dissódico $\left(\mathrm{Na}_{2} \mathrm{HPO}_{4}, 12 \mathrm{H}_{2} \mathrm{O}\right)$ $2,9 \mathrm{~g}$

água destilada $1.000 \mathrm{~mL}$

Dissolver todos os ingredientes na água destilada e acertar o pH em 7,4 Manter a solução em geladeira. 


\section{PBS $0,05 \mathrm{M}$ acrescido de "Tween 20 "}

Adicionar $0,5 \mathrm{~mL}$ de "Tween 20 " para cada $1.000 \mathrm{~mL}$ de solução de PBS.

\section{Tampão fosfato $\mathrm{pH} 6,5 / 0,1 \mathrm{M}$ para coloração de esterase}

soluções estoque $A(0,2 \mathrm{M})$

fosfato monobásico de sódio $\left(\mathrm{NaH}_{2} \mathrm{PO}_{4} \mathrm{H}_{2} \mathrm{O}\right)$

$27,58 \mathrm{~g}$

água destilada

$1.000 \mathrm{~mL}$

soluções estoque $B(0,2 \mathrm{M})$

fosfato de sódio anidro $\left(\mathrm{Na}_{2} \mathrm{HPO}_{4}\right)$

$28,38 \mathrm{~g}$

água destilada

$1.000 \mathrm{~mL}$

Juntar $68,5 \mathrm{~mL}$ da solução $A$ com $31,5 \mathrm{~mL}$ da solução $B$ e dobrar o volume com água destilada. $\mathrm{O}$ pH estará automaticamente ajustado em 6,5.

\section{Gel de poliacrilamida}

bis-acrilamida

$0,30 \mathrm{~g}$

acrilamida

$5,70 \mathrm{~g}$

TEMED

$0,10 \mathrm{~mL}$

persulfato de amônia $2,0 \%$.

$2,80 \mathrm{~mL}$

tris-glicina

qsp $\quad 100 \mathrm{~mL}$

O bis-acrilamida e a acrilamida após pesagem eram colocados em um becker e diluídos em pequeno volume do tampão tris-glicina. $O$ volume era então completado para $100 \mathrm{~mL}$, com o próprio tampão. A solução obtida era então filtrada em gaze para outro recipiente quando se adicionava O TEMED e 0 persulfato de amônia e se vertia, imediatamente, na cámara preparada pelas placas de vidro. 


\section{Solução corante de esterase}

solução de "Fast blue"

"Fast blue"

$50 \mathrm{mg}$

tampão fosfato $\mathrm{pH} 6,5$ $100 \mathrm{~mL}$

Macerar o "Fast blue" no tampão, com bastão de vidro, filtrar em gaze. soluçăo de acetato

alfa naftil-acetato $20 \mathrm{mg}$

acetona/água $50 \%$ $2,0 \mathrm{~mL}$

Juntar as duas soluções recém preparadas somente no momento de uso.

\section{Solução secante}

metanol $50 \mathrm{~mL}$

ácido acético $75 \mathrm{~mL}$

água destilada $100 \mathrm{~mL}$

glicerina $10 \mathrm{~mL}$

Juntar todos os ingredientes e emulsionar. Manter em frascos. 


\section{1. Ágar gema de ovo}

BHI ágar (difco) $13 \mathrm{~g}$

água destilada $250 \mathrm{~mL}$

0 meio era dissolvido por aquecimento em banho fervente e a seguir submetido a esterilização em autoclave a $120^{\circ} \mathrm{C}$ por 15 minutos. Após a esterilizaçăo o meio era resfriado a aproximadamente $45^{\circ} \mathrm{C}$ e adicionado de $10 \%$ de solução de gema de ovo a 50\%. Após a homogenização o emio era distribuído, assepticamente, em placas de Petri esterilizadas, em volumes aproximados de.15 $\mathrm{mL}$ por placa. Assim que houvesse a solidificação do ágar as placas eram colocadas em geladeira e ai mantidas por até uma semana.

\section{Emulsão de gema de ovo a $50 \%$}

gema de ovo $20 \mathrm{~mL}$

água destilada esterilizada $20 \mathrm{~mL}$

Um ovo de galinha de criação caseira era lavado com água e sabão e a seguir mantido por uma hora em álcool etílico $70 \%$. Após este período o ovo era quebrado assepticamente, a gema colocada em cálice graduado e o volume dobrado com água destilada esterilizada. A emulsão era realizada com auxilio de bastão de vidro e a seguir passada por gaze esterilizada antes de ser adicionada ao ágar.

\section{Solução de tripsina}

tripsina (difco)

água destilada

\section{$2,5 \mathrm{~g}$}

$100 \mathrm{~mL}$

Esta solução era filtrada em membrana esterilizante e o pH ajustado em 6,2. A seguir era distribuida assepticamente em volumes de $5 \mathrm{~mL}$ em frascos já esterilizados que eram mantidos a $-4^{\circ} \mathrm{C}$

\section{Reativo para o teste de Antrona}

solução de antrona a $1,0 \%$ em acetato de etila 